UNIVERSIDADE DE SÃO PAULO

FACULDADE DE FILOSOFIA, LETRAS E CIÊNCIAS HUMANAS

DEPARTAMENTO DE LETRAS MODERNAS

PROGRAMA DE PÓS-GRADUAÇÃO EM LÍNGUA E LITERATURA ALEMÃ

MARCOS ANTÔNIO ALVES ARAÚJO FILHO

Verbos com o prefixo ver- na língua alemã: uma análise construcionista.

VERSÃO CORRIGIDA

São Paulo

2013 


\title{
Verbos com o prefixo ver- na língua alemã: uma análise construcionista.
}

\author{
VERSÃO CORRIGIDA
}

Marcos Antônio Alves Araújo Filho

Dissertação apresentada ao Programa de Pós Graduação em Língua e Literatura Alemã da Faculdade de Filosofia, Letras e Ciências Humanas da Universidade de São Paulo como requisito para obtenção do título de Mestre em Língua e Literatura Alemã.

Área de concentração: Língua e Literatura Alemã.

Orientadora: Profa. Dra. Maria Helena Voorsluys Battaglia

São Paulo 


\section{Sumário}

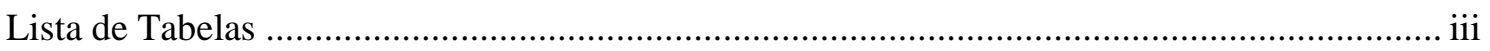

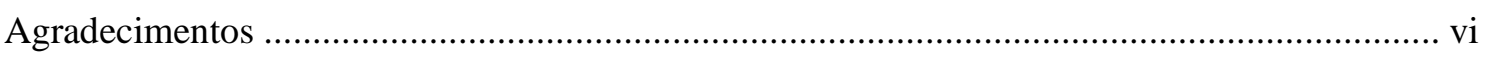

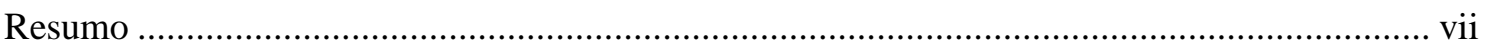

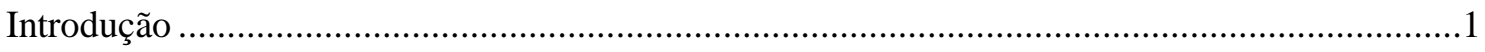

1- FUNDAMENTAÇÃO TEÓRICA ............................................................................

1.1 - Fundamentos de morfologia da língua alemã ...............................................6

1.1.1. Relevância para a análise do objeto de pesquisa ..........................................6

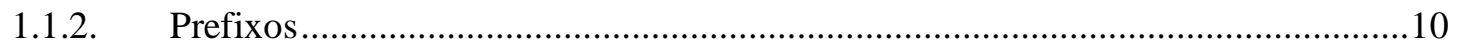

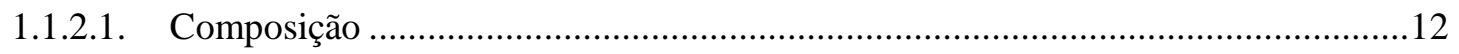

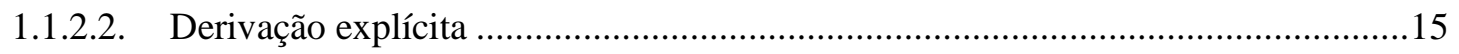

1.2- Princípios e conceitos da teoria da gramática de construções....................................19

1.2.1. Relevância para a análise do objeto de pesquisa ...........................................19

1.3 - Teoria da mesclagem - Fauconnier \& Turner (2003) .............................................31

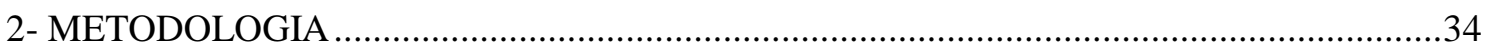

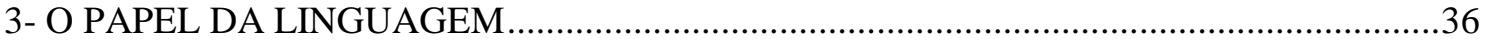

4- ANÁLISE DOS VERBOS .................................................................................45

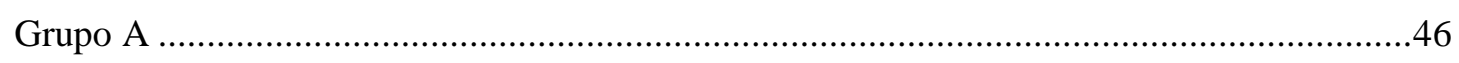

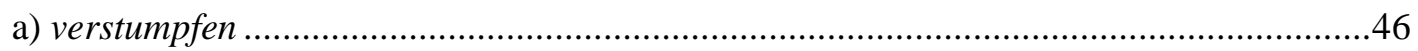

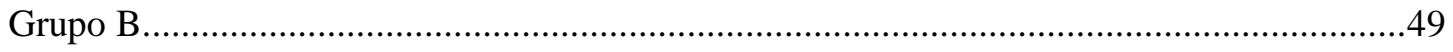

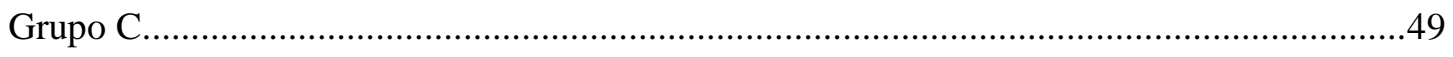

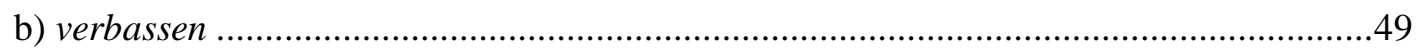

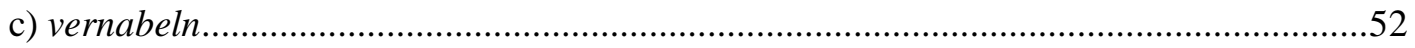

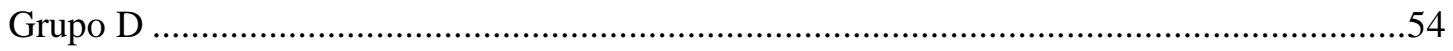

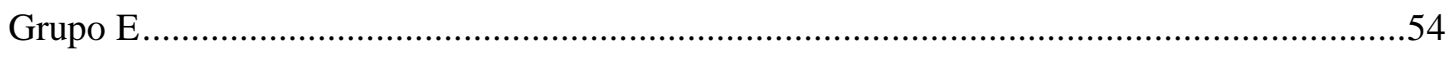




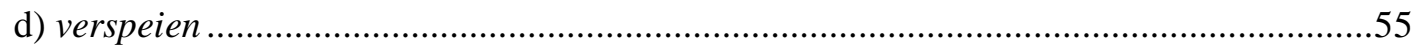

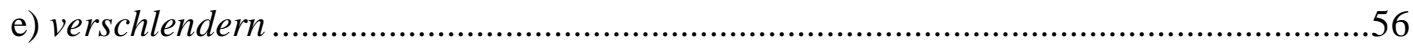

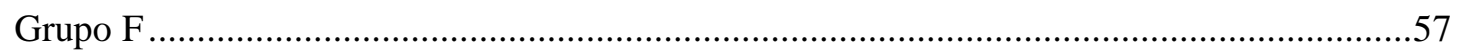

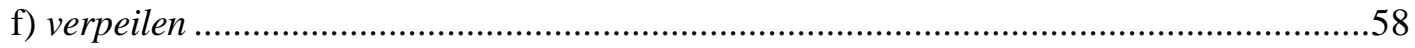

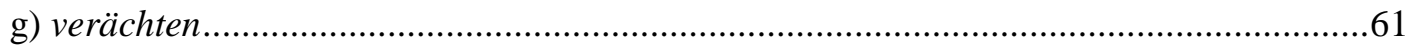

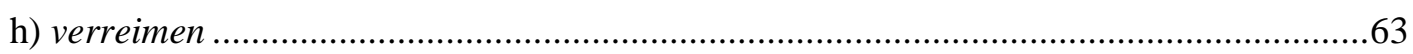

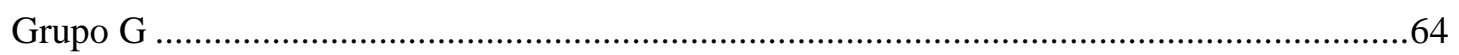

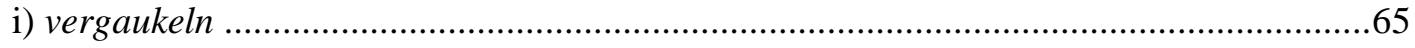

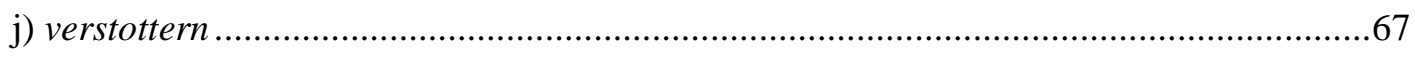

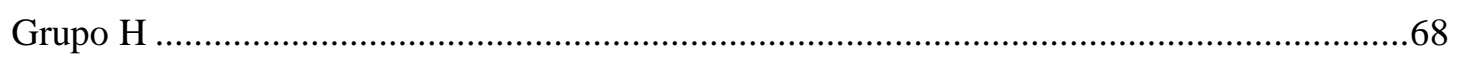

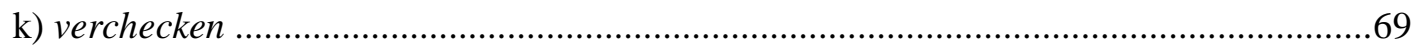

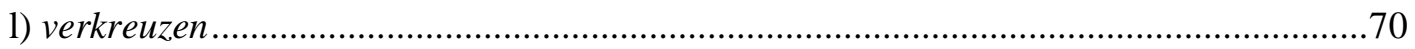

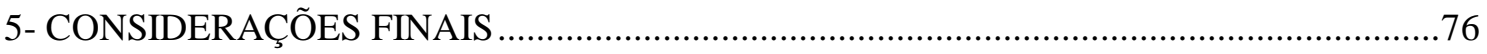

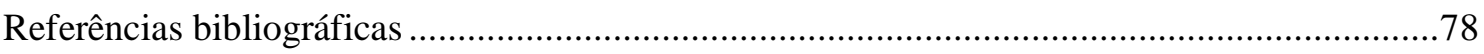

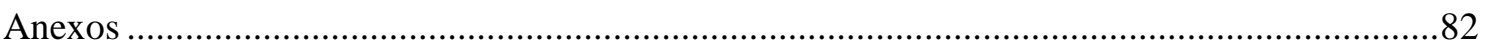

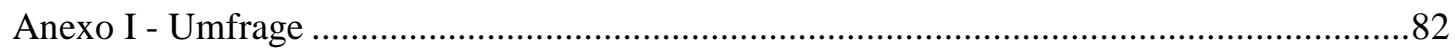

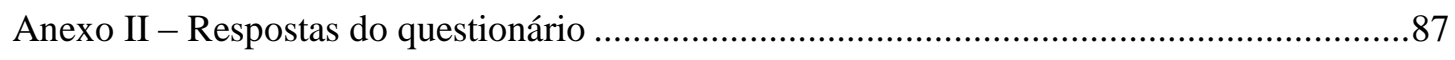

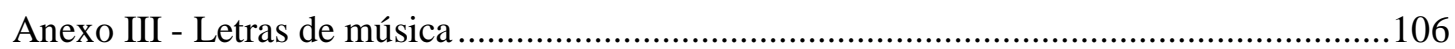




\section{Lista de Figuras}

Figura 1: Rede polissêmica de ver-

Figura 2: Mesclagem conceptual, adaptado de FAUCONNIER \& TURNER (2003, p 3). 32

\section{Lista de Tabelas}

Tabela 1: mesclagem conceptual referente ao verbo verstumpfen. .48

Tabela 2: mesclagem conceptual referente ao verbo vernabeln. .53 


\section{Verbos com o prefixo ver- na língua alemã: uma análise construcionista.}

Dissertação apresentada ao Programa de Pós Graduação em Língua e Literatura Alemã da Faculdade de Filosofia, Letras e Ciências Humanas da Universidade de São Paulo como requisito para obtenção do título de Mestre em Língua e Literatura Alemã.

Professora Doutora Maria Helena Voorsluys Battaglia (Orientadora) - USP

Professora Doutora Eva Maria Ferreira Glenk - USP

Professora Doutora Ulrike Schröder - UFMG 
“... A marcação do baixo nos sambas muito impressionara os músicos locais.

Claro, 'bossa' era uma corruptela de 'bass', contrabaixo em inglês.

Tudo esclarecido."

Luis Fernando Veríssimo 


\section{Agradecimentos}

Em primeiro lugar, gostaria de agradecer aos meus queridos pais o incentivo e o apoio na realização de meus projetos, acreditando na minha capacidade! Como é grande o meu amor por vocês!

Aos meus irmãos, as conversas recheadas de conselhos e cumplicidade. Vocês são muito importantes para mim.

Às queridas Tia Regina e Tivi, que acompanharam minha trajetória e sempre estiveram na torcida pelo meu sucesso profissional.

À Vó Mena e ao Tio Firmino, a proteção.

À Maria Helena, minha orientadora, os valiosos conselhos e ensinamentos ao longo desse período. Certamente, sua dedicação é refletida em meu trabalho.

Ao amigo Leonardo Coscarelli, a amizade com as boas horas de conversa que pouparam sessões de terapia.

À amiga Brunildes, o apoio e os conselhos sinceros, que muito me incentivaram na realização deste trabalho. Você brilha!

Minha gratidão àqueles que me ajudaram na parte prática do trabalho, seja nas traduções ou na coleta de informantes: Professora Ulrike Schröder, professor Georg Otte, minha querida amiga Fernanda Fernandes, a amiga distante Corinna Wille e Leonie.

À CAPES, o apoio financeiro nessa importante etapa de minha carreira profissional.

Ao Igor, meu companheiro, que dividiu as angústias e alegrias dessa atribulada fase, sem descuidar da atenção e do carinho. 


\section{Resumo}

O prefixo ver- já foi tema de estudo para diversos linguistas que se dedicam à língua alemã (LEOPOLD, 1907; SCHIRMEIER, 2006, entre outros). O caráter polissêmico desse prefixo é o grande motivo para tamanho interesse. Diferentemente dos trabalhos citados, esta dissertação analisa novas formações verbais com o prefixo ver-, a fim de descobrir regularidades, tanto semântica quanto morfológicas no processo de formação dos verbos. Para tanto, pesquisamos novos verbos ainda não lexicalizados em um sítio eletrônico (http://www.deflok.de/HipHopLyrics/Texte/), composto por letras de música do hip hop alemão. Assim, o endereço virtual foi tomado como corpus para a tarefa. A busca permitiu encontrar doze novos verbos: verbassen, verspeien, verpeilen, verchecken, verächten, verkreuzen, verstumpfen, vergaukeln, verschlendern, vernabeln, verreimen, verstottern. Para tanto, os dicionários DUDEN (www.duden.de), Langescheidt (versão digital) e PONS (versão digital) foram usados como ferramenta de exclusão lexicográfica. O dicionário DUDEN funcionou também como fonte para conhecer as acepções que o prefixo ver-imprimia nos derivados em que se encontrava. $\mathrm{O}$ arcabouço teórico usado teve como base os conceitos da teoria da gramática de construções, a partir de GOLDBERG (1995) que permitiram conhecer novas propostas de interpretação dos mecanismos envolvidos na formação dos verbos com o prefixo ver. Ademais, recorremos à teoria da mesclagem de FAUCONNIER \& TURNER (2003) para explicar a construção de sentido de determinados verbos, uma vez que essa permitia explorar aspectos não contemplados pela teoria da gramática de construções.

Palavras-chave: prefixo ver-, neologismos, hip hop, gramática de construções, teoria da mesclagem. 


\begin{abstract}
The prefix ver- has already been a theme of many linguistics (LEOPOLD, 1907; SCHIRMEIER, 2006, and others), that are dedicated to German language. The polissemic aspect from this prefix is the main reason for such a big interest. Unlike those authors, with this paper I analyse new verbal formations with the prefix ver- in order to discover semantic as well as morphological regularities in the process of verbal formations. Therefore, I researched new not yet lexicalized verbs in a website (http://www.deflok.de/HipHopLyrics/Texte/), composed of hip hop lyrics in German. The web address was treated as the corpus. Twelve new verbs were detected: verbassen, verspeien, verpeilen, verchecken, verächten, verkreuzen, verstumpfen, vergaukeln, verschlendern, vernabeln, verreimen, verstottern. In order to verify that these verbs were not yet lexicalized we used the following dictionaries: DUDEN (www.duden.de) and the digital version of Langenscheidt, and PONS. The dictionary DUDEN also served to specify the different meaning, that the prefix ver- gives to the derivates, in which it is part of. The theoretical support is based on the terms and definitions of the construction grammar (Goldberg, 1995), that allowed to get a new point of view about the mechanisms involved in the verb formation with the prefix ver-. Complementary I employed the definitions proposed by FAUCONNIER \& TURNER (2003) to explain the meaning of certain neologism to which the construction grammar theory could not be applied.
\end{abstract}

Key-Words: prefix ver-, neologisms, hip hop, constructions grammar, Blending theory. 


\section{Zusammenfassung}

Zahlreiche Autoren (LEOPOLD, 1907; SCHIRMEIER, 2006; unter anderen), die sich der deutschen Sprache widmen, beschäftigten sich schon mit dem Präfix ver-. Der mehrdeutige Aspekt des Präfixes ist der Hauptgrund für dieses Interesse. Anders als die genannten Autoren analysiere ich in dieser Masterarbeit die neuen verbalen Bildungen mit dem Präfix ver-, um sowohl semantische als auch morphologische Regelmäßigkeiten in den Wortbildungen zu untersuchen. Dafür habe ich die neuen und noch nicht lexikalisierten Verben auf einer Webseite (http://www.deflok.de/ HipHopLyrics/Texte/) recherchiert. Diese Adresse enthält Musiktexte aus dem hip hop und wird als corpus betracht. Bei der Suchanfrage wurden zwölf neue Verben gefunden, und zwar: verbassen, verspeien, verpeilen, verchecken, verächten, verkreuzen, verstumpfen, vergaukeln, verschlendern, vernabeln, verreimen, verstottern. Die Wörterbücher DUDEN (www.duden.de), Langenscheidt (digitalisierte Version) und PONS (digitalisierte Version) dienten als Nachschlagwerke. Das Wörterbuch DUDEN wurde auch als Quelle benutzt, um die verschiedenen Bedeutungen des Präfixes verkennen zu lernen. Den theoretische Rahmen für diese Forschungsarbeit bilden die Begriffe der Konstruktionsgrammatik von GOLDBERG (1995), die mir erlaubten, das Thema aus einer anderen Perspektive zu betrachten. Dies wurde noch ergänzt durch wichtige Aspekte der Blendingtheorie von FAUCONNIER \& TURNER (2003). Für bestimmte Verben nutze ich diese Theorie, um die Bedeutung der erwähnten Neologismen zu erklären, da die Konstruktionsgrammatik bei ihnen nicht anwendbar war.

Schlüsselwörter: Präfix ver-, Neologismen, Hip Hop, Konstruktionsgrammatik, Blending-Theorie 


\section{Introdução}

O desafio de aprender uma língua estrangeira exige dedicação e persistência. As dificuldades que envolvem o processo de aprendizado não são apenas de ordem sintática, mas também discursiva, semântica, entre outras. Felizmente, algumas estratégias contribuem para o aprendizado de língua estrangeira. No caso da língua alemã, por exemplo, conhecer os prefixos pode ajudar a desvendar o significado de alguns verbos, assim como reconhecer as partes de um composto pode ser um recurso útil para interpretar certas palavras. O substantivo Kühlschrank é um composto que pode ser desmembrado em unidades menores, por exemplo: kühl (frio, gelado) e Schrank (armário). Esses morfemas já possuem significados separadamente e a simples associação de ambos remete à imagem do popular eletrodoméstico geladeira. Obviamente tal recurso não é válido em todas as palavras da língua e muitas entradas lexicais ou partes delas parecem querer apenas sugerir significados, a exemplo dos verbos formados pelo prefixo ver-.

Como veremos adiante, o ver- é um prefixo que não se manifesta isoladamente na língua alemã, portanto não tem significado próprio. Contudo, quando ligado a certos verbos, substantivos ou adjetivos, o prefixo assume diferentes significados que podem dificultar o aprendizado. Quando comparamos o verbo fahren, por exemplo, com seu correspondente prefixado verfahren, devemos ter em mente a conotação de erro no segundo; enquanto fahren significa "mover-se com algum veículo para algum lugar", verfahren indica que o condutor se perde pelo caminho percorrido com o veículo. Por outro lado, o verbo verkleinern comparado ao adjetivo klein não possui a mesma significação de erro; ele indica apenas a ação de diminuir algo.

Assim, a proposta deste trabalho surgiu a partir da dificuldade de se traçar um perfil semântico para o referido prefixo, dado o seu aspecto polissêmico. As gramáticas e livros especializados (cf. DUDEN online, LEOPOLD, 1907, e.o) postulam diferentes significados para ver- e, com o objetivo de conhecê-los melhor, pesquisamos verbos 
com o prefixo ainda não dicionarizados em canções do hip hop para verificar a abrangência dessa variedade de sentidos.

Devido à semelhança de atribuições ao ver- em alguns verbos e, ao mesmo tempo, à existência de significados díspares em outros, o prefixo tornou-se objeto de investigação para mim. No exercício da profissão, o professor de alemão como língua estrangeira é confrontado com dúvidas de alunos, não apenas quanto à sintaxe, como também quanto à semântica das palavras. Não raro os questionamentos envolvem a relação semântico-sintática entre os prefixos e as bases às quais se ligam. Dentre as formas preconizadas de ensino de vocabulário (cf. Scherfer, 1995) em aulas de língua estrangeira, a adivinhação de palavras (Vokabelraten) é um exercício que visa promover a autoreflexão do aluno. Nesse modelo estimula-se o aprendiz a buscar em seu conhecimento prévio de língua e suas experiências pessoais a resposta para o entendimento do vocabulário:

\begin{abstract}
Nesses exercícios, o vocabulário desconhecido não é totalmente esclarecido. O aluno é convidado a desvendar por si só o significado das palavras com base em seu conhecimento de mundo, devido ao seu conhecimento de língua, tanto materna quanto estrangeira (esquemas de formação de palavras, internacionalismos, contextos gramaticais típicos, regras de construção textual e de argumentação). ${ }^{1}$ (SCHERFER, 1995 p.230).
\end{abstract}

O interesse pela atual pesquisa surgiu, então, devido à tentativa de estabelecer relações de aprendizado. De maneira pontual, podemos afirmar que a origem para este estudo científico foram os prefixos em geral; ou seja, prefixos que acompanham verbos separáveis e também não separáveis. Mas, diferentemente de grande parte dos prefixos da língua, que também desempenham o papel de preposições, o prefixo ver- é um morfema que nunca se manifesta isoladamente; daí ser classificado como gebundenes Morphem (morfema preso), conforme Linke: "morfemas presos nunca se apresentam na forma de palavra independente, como -bar em fruchtbar, -heit em Gottheit, -en em

\footnotetext{
${ }^{1}$ No original: "bei diesen Übungen werden (...) die unbekannten Vokabeln nicht alle erklärt, sondern der Schüler wird aufgefordert, bestimmte Vokabeln auf Grund seiner vorhandenen (mutter- und fremdsprachlichen) Sprachkenntnisse (Wortbildungsschemata, Internationalismen, typische grammatische Kontexte, Regeln für den Aufbau von Texten und Argumentationen) und auf der Basis seines Weltwissens selbst zu erschliessen." (SCHERFER, 1995 p.230). Todas as traduções são de minha responsabilidade.
} 
gott-heit-en."2. Tal característica distingue-o das preposições como freie Morpheme (morfemas livres), que assumem valores sintáticos reais. Dessa maneira, no alemão, o ver- existe apenas na forma de prefixo de verbos inseparáveis ou junto a adjetivos e substantivos.

Assim como outros prefixos de verbos inseparáveis, o prefixo ver- revela-se um morfema de difícil interpretação, como visto anteriormente. Portanto, faz-se necessário adotar um estudo de natureza semasiológica. Conforme Pörings, "no procedimento semasiológico primeiramente é captada a polissemia de uma palavra, são listados os significados e em seguida é descrito, qual relação podemos estabelecer entre eles."3 (PÖRINGS, 1999 p.28). O autor explica também a etimologia do termo "polissemia": “do grego poly 'muitos' e sema 'desenho', significado”4 (PÖRINGS,1999 p.28), daí o sentido de diversidade de atribuições a uma palavra específica.

Tendo em vista o caráter polissêmico do ver- e a reconhecida importância da análise semântica para o entendimento de formações de qualquer natureza na língua alemã, o objetivo deste estudo é analisar as novas formações verbais com o prefixo verdo ponto de vista morfológico e semântico.

A fim de encontrar novos verbos com o prefixo tomamos como corpus de pesquisa um sítio na internet composto por letras de música do gênero hip hop. Após a identificação dos novos verbos, descrevemos o processo pelo qual eles foram formados, se provenientes de adjetivos, substantivos ou mesmo verbos. Tal análise busca conhecer regularidades e relações semânticas envolvidas nos neologismos com o prefixo ver-.

Outros trabalhos já trataram do prefixo ver- anteriormente, mas com enfoques distintos. Entre outras questões, Pinto Junior (1987) analisa a formação dos verbos com o referido prefixo e as diferenças semânticas entre o verbo prefixado e o verbo simples. Schirmeier (2006), por seu turno, aplica testes de decisão lexical em falantes nativos de

\footnotetext{
${ }^{2}$ No original: “Gebundene Morpheme treten dagegen nie als sebstständige Wortform auf, so etwa-bar in frucht-bar, -heit, in gott-heit, -en in gott-heit-en." (LINKE, 1996 p. 61)

${ }^{3}$ No original: "bei einem semasiologischen Verfahren wird zunächst die Polysemie einer Wortform erfasst, die einzelnen Bedeutungen werden aufgelistet, und in einem nächsten Schritt wird beschrieben, in welcher Beziehung diese zueinander stehen." (PÖRINGS, 1999 p.28)

${ }^{4}$ No original: "griech. Poly 'viel' und sema 'Zeichen', Bedeutung" (PÖRINGS,1999 p.28)
} 
língua alemã para estudar a influência das raízes verbais no reconhecimento dos verbos com prefixo ver-. Diferentemente dos autores citados, nosso foco reside na motivação semântico-morfólogica das novas formações verbais ainda não dicionarizadas. Assim, alguns questionamentos direcionaram o presente estudo: Uma vez que investigamos novos verbos com ver-, qual seria afinal o significado desse nos derivados encontrados? Há um significado que seja mais usual? Se os significados são tão diversos, a qual processo cognitivo o falante recorre quando da criação de novas palavras com o prefixo?

Para tanto, esta dissertação dividiu-se em cinco partes, afora a presente introdução.

O capítulo 1 trata dos fundamentos teóricos. Devido a sua importância e extensão, o capítulo é dividido em três partes: 1.1. Fundamentos de morfologia da língua alemã - parte dedicada à teoria de formação de palavras no idioma. Uma vez que analisamos verbos derivados prefixados da língua alemã torna-se imperativo conhecer os processos que permitem suas formações; 1.2. Princípios e conceitos da teoria da gramática de construções. Neste subcapítulo apresentamos um esboço da teoria da Gramática das Construções para explicar posteriormente como seus princípios se aplicam a nossos exemplos; 1.3. Teoria da mesclagem. Alguns aspectos do significado de derivados não são contemplados pela gramática de construções. Assim, recorremos à teoria da mesclagem (Fauconnier \& Turner, 2003) para explicar a construção do significado desses casos específicos.

No capítulo 2 será detalhado o corpus utilizado no trabalho. Assim, essa parte é dedicada à metodologia de pesquisa aplicada e descreve o procedimento adotado para encontrar os novos verbos com o prefixo ver- na língua alemã.

O capítulo 3 trata do papel da linguagem. A música oferece as possibilidades de uma língua através da linguagem. Este item revela a importância do gênero textual "letra de música" para a formação de neologismos, entendido neste trabalho como a criação de novas palavras ainda não dicionarizadas. 
Na sequência, o capítulo 4 descreve o estudo realizado para cada verbo novo - é a análise propriamente dita dos verbos encontrados. Neste capítulo são aplicados os conceitos e regras que explicam as construções com o prefixo ver-, conforme proposto pela teoria da gramática de construções.

Por fim, o capítulo 5 é dedicado às considerações finais do estudo. Na última parte são apontadas reflexões acerca da interpretação dos verbos com prefixo ver- na língua alemã enquanto construções, bem como seus resultados. 


\section{1- FUNDAMENTAÇÃO TEÓRICA}

\section{1- Fundamentos de morfologia da língua alemã}

\subsubsection{Relevância para a análise do objeto de pesquisa}

A morfologia é o estudo das palavras e suas formas. Tal estudo compreende identificar a estrutura das palavras e seus processos de formação, tarefas de fundamental importância no presente trabalho, uma vez que os neologismos encontrados com o prefixo ver- obedecem invariavelmente às regras de formação de palavras da língua alemã.

Primeiramente, há uma diferença conceitual a ser considerada nos estudos de morfologia referente às palavras novas. A necessidade refere-se a dois termos que apresentam nuances de significação e podem ser facilmente confundidos, quais sejam: Wortbildung (formação de palavras) e Wortschöpfung (criação de palavras).

Conforme Naumann (2000), a formação de palavras é por definição "pesquisa e significação de procedimentos e regularidades na formação de novas palavras complexas com base em meios linguísticos existentes." (NAUMANN, 2000 p. 2). A definição do termo criação de palavras, por outro lado, leva em consideração a finalidade do fenômeno. $\mathrm{O}$ autor aponta as diferenças conceituais: "em contraste com a formação de novas palavras através da derivação e composição (...) por meio de elementos linguísticos existentes, a criação de palavras baseia-se no primeiro uso de uma sequência de sons como expressão (não motivada) para um significado específico."6 Congruente com tais definições, Donalies adota, porém, o termo Urschöpfung para referir-se a Wortschöpfung. Ao diferenciar os fenômenos, podemos notar que sua definição de criação de palavras não é restritiva como o é para Naumann:

$\mathrm{Na}$ formação de palavras, as palavras são construídas com material linguístico dotado de sentido e isso a difere do processo da criação, no qual

\footnotetext{
5 No original: "Untersuchung und Bedeutung von Verfahren und Gesetzmäßigkeiten bei der Bildung neuer komplexer Wörter auf der Basis vorhandener sprachlicher Mittel.” (NAUMANN, 2000 p. 2).

${ }^{6}$ No original: "Im Unterschied zur Wortneubildung durch Ableitung und Zusammensetzung (...) mittels vorhandener sprachlicher Elemente beruht Wortschöpfung auf der erstmaligen Verwendung einer Lautfolge als (unmotivierter) Ausdruck für eine bestimmte Bedeutung." (BUßMANN, 1983, P.591 apud NAUMANN, 2000 p. 2).
} 
as palavras são formadas por sons, que anteriormente ainda não haviam sido completamente formados de sentido. ${ }^{7}$ (DONALIES, 2007 p. 4).

Naumann e Donalies adotam critérios diferentes para a classificação dos termos; enquanto aquele enfatiza propriedades estruturais das formações, essa atenta para a semântica dos componentes. Como veremos adiante, os verbos encontrados para este estudo são construções que apresentam regularidades e obedecem a regras gramaticais bem definidas. A partir de análises de suas estruturas, consideramos que o conceito desenvolvido por Naumann (2000) seja o mais adequado para nosso estudo, devido à sistematização observada nos neologismos encontrados. Portanto, nosso trabalho pode ser caracterizado como uma pesquisa sobre formação de palavras, nos termos propostos por Naumann (2000).

Na língua portuguesa, Castilho (2010) não discute a diferença dos conceitos, mas usa o termo "lexicalização" para referir-se à criação de palavras, cujos processos são: etimologia, neologismo ou empréstimo (CASTILHO, 2010 p. 110). Nos estudos de língua alemã, contudo, a diferenciação e o correto uso dos termos "Wortschöpfung" e "Wortbildung" é um procedimento necessário para a correta delimitação do nosso campo de estudo.

Geralmente, as formações com o prefixo ver- são constituídas de verbos com significação própria, acrescidos do prefixo. Um caso emblemático é o verbo 'vergessen' que configura uma exceção a essa regra. Nesse exemplo, "gessen" já não é mais uma entrada lexical - hoje o termo é opaco de sentido (cf. Kluge, 2002; Heide, 2006). Mas, uma vez que a maioria dos verbos são completos de sentido, qual relação podemos estabelecer, afinal, com o prefixo em questão? A teoria da semântica cognitiva sugere interpretar os vocábulos da língua a partir de representações imaginativas, como proposto por Bellavia (2007): “o uso de figuras tridimensionais parece-me importante para explicar processos mentais que se encontram na base de extensões semânticas."8 Nesse estudo, Bellavia analisa o morfema "um" em diferentes situações, com três

\footnotetext{
${ }^{7}$ No original: "Dass bei der Wortbildung Wörter aus sinnhaltigem Sprachmaterial gebildet werden, unterscheidet sie von der Urschöpfung, bei der Wörter aus Lauten gebildet werden, die vorher so noch nicht sinnvoll zusammengesetzt waren." (DONALIES, 2007, p. 4).

${ }^{8}$ No original: "scheint mir die Verwendung dreidimensionaler Bilder zur Erklärung der mentalen Prozesse, die auf der Basis semantischer Erweiterungen stattinden, wichtig zu sein." (BELLAVIA, 2007, p. 81).
} 
funções distintas na língua alemã, a saber, como preposição, como prefixo de verbo inseparável $^{9}$ e como prefixo de verbo separável ${ }^{10}$. Na qualidade de preposição, o morfema "um" já se mostra dotado de significado e, consequentemente, seu espectro pode assumir outras funções - há uma ampliação em seu uso. Mas e no caso de ver-? Como vimos anteriormente, o morfema sempre acompanha verbos, adjetivos ou substantivos.

Na bibliografia consultada, as gramáticas da língua alemã e até mesmo manuais de linguística alemã tratam a questão do significado de verbos com o prefixo ver- de maneira superficial e deixam a cargo do leitor a tarefa de depreender seus sentidos, como indicam os exercícios: "Beschreiben Sie die Bedeutungen des Präfixes ver- in den gegenwartssprachlichen Verben verblühen, verzuckern, verbauen, verkalken, versetzen..." (NAUMANN, 2000 p. 58). Hall \& Scheiner (2011) no livro Übungsgrammatik für Fortgesschrittene oferecem uma relação de frases a serem completadas e algumas opções de verbos que poderiam construí-las: "Wie kam das? Vervollständigen Sie die Sätze mit den jeweils passenden Verben im Perfekt: verfallen, vertrocknen, aussterben, eingehen... Beispiel: Weil das Holz lange im Feuer lag,... (ist es verkohlt). "12 (HALL \& SCHEINER, 2011, p.17). Essa forma de exercício ajuda na aquisição de vocabulário, mas também não explica o valor semântico do prefixo. Ainda em outro material, Eisenberg (2006) refere-se a funções que o prefixo desempenha em formações verbais. Esta atividade é focada na análise de morfemas que constituem as palavras alemãs, dentre eles, o prefixo ver-: “Beschreiben Sie die Funktion von ver in folgenden Verbklassen: a) verarbeiten, verbauen, verbraten, verbrauchen, verfressen, verfüttern, verheizen, verplempern, verspielen, vertrinken, vertrödeln."13 (EISENBERG, 2006, p.381)

Como visto anteriormente, conhecer os processos de formação das palavras na língua alemã é de fundamental importância para entender o comportamento do prefixo ver-. A esse respeito, Naumann comenta:

\footnotetext{
${ }^{9}$ Präfix

${ }^{10}$ Nachverb

${ }^{11}$ Descreva o significado do prefixo ver- nos verbos da linguagem moderna: murchar, açucarar, gastar em exagero na construção, calcificar, deslocar.

${ }^{12}$ Como aconteceu isso? Complete as frases com os verbos adequados no tempo perfeito: decair, ressecar, extinguir... Exemplo: uma vez que a madeira ficou muito tempo no fogo... (ficou carbonizada).

13 Descreva a função de ver- nas seguintes classes verbais: a) verarbeiten, verbauen, verbraten, verbrauchen, verfressen, verfüttern, verheizen, verplempern, verspielen, vertrinken, vertrödeln."
} 
Este processo é ainda eficaz; mesmo no alemão atual também são encontradas mudanças. Conforme princípio científico geral do Uniformitarianismus, os desenvolvimentos históricos da língua atual são estruturalmente comparáveis, eles são estruturalmente atemporais: determinados componentes de composição tomam a função de afixos, isto é, surgem novas formas prefixais e sufixais em substantivos, adjetivos e verbos. ${ }^{14}$ (NAUMANN 2000, p. 48)

O grande número de partículas, prefixos e sufixos entre outros na língua alemã permite ao falante explorar a língua com relativa liberdade. Entretanto, a combinação dos elementos citados não é aleatória e os processos de formação são sistematizados e categorizados na vasta literatura disponível (cf. Booij et. al., 2000; Donalies, 2007). No material analisado, a obra de Donalies (2007) Basiswissen Deutsche Wortbildung destaca-se pela abordagem detalhista dada ao tema e, por isso, baseamos-nos nela para descrever os principais processos de formação de palavras, que interessam nesta pesquisa. O material também foi publicado no sítio do IDS (Institut der deutschen Sprache $)^{15}$.

Donalies (2007) identifica primeiramente as unidades formadoras de palavras, também chamadas "pedras construtoras". Tais unidades podem ser palavras, frases, sílabas, confixos, afixos, unidades únicas e os chamados elementos de ligação ${ }^{16}$.

Para a presente pesquisa é relevante, sobremaneira, o detalhamento sobre os afixos. Os afixos são unidades que só podem surgir acompanhadas de uma palavra e por isso são denominados morfemas presos: "Afixos de formação de palavras (do latim affigere, aderir, anexar a algo) como un-, ver-, -heit, -lich não ocorrem livres como as palavras em textos e também não podem ser aproveitados por afixos de flexão." ${ }^{17}$ (DONALIES, 2007, p.15).

\footnotetext{
14 No original: "Dieser Prozess ist noch wirksam; auch in der deutschen Gegenwartssprache finden Veränderungen statt. Nach dem allgemeinen Wissenschaftsprinzip des Uniformitarianismus sind historische Entwicklungen denen der Gegenwartssprache strukturell vergleichbar, sie sind strukturell zeitlos: Bestimmte Kompositionsglieder nehmen die Funktionvon Affixen ein, d.h. neue prä- und suffigierte Formen entstehen, bei Substantive, Adjektiven und Verben." (NAUMANN, 2000, p. 48)

${ }^{15} \mathrm{http}$ ://hypermedia.ids-mannheim.de/call/public/sysgram.ansicht (acesso em 15/03/2011)

16 O termo 'Fugenelemente' foi assim traduzido pela função desempenhada na língua portuguesa, conforme Bechara (2009): "vogais e consoantes de ligação que, (...) se intercalam para facilitar a pronúncia ou para evitar hiatos...".

${ }^{17}$ No original: "Wortbildungsaffixe (zu lat. affigere, anheften, an etwas befestigen) wie un-, ver-, -heit, lich kommen anders als Wörter nicht frei in Texten vor und können auch nicht durch Flexionsaffixe nutzbar gemacht werden..." (DONALIES, 2007, p.15).
} 
Os afixos diferenciam-se dos confixos pelo fato de não serem combináveis entre si e são classificados em três categorias, conforme seus efeitos na palavra formada: de transposição, determinantes e determinados. Os afixos de transposição caracterizam-se pela mudança de classe gramatical sem alteração de categoria semântica: zart (delicado, sensível) / (adjetivo) - Zartheit (delicadeza) / (substantivo). Já os afixos determinantes são também caracterizados por um fenômeno semântico; a saber, a marcação mais exata de unidades: "-chen" é determinante de "Kindchen" (criancinha), uma vez que especifica o tipo de criança: pequena. O terceiro tipo são afixos determinados, conforme Donalies (2007, p.16): “vergolden indica uma atividade produzida com ver-, na qual algo recebe ouro na superfície: os restauradores banham a ouro a grade de ferro." ${ }^{18}$ Aqui há uma mudança gramatical da raiz: o substantivo Gold (ouro) é verbalizado ao receber o prefixo ver- e o morfema "-en", desinência de verbo no infinitivo.

Ainda quanto à classificação dos afixos, eles podem ser nomeados conforme a posição que ocupam na palavra: os prepostos à raiz são chamados "prefixos", os pospostos são denominados "sufixos" e quando ocorrem, simultaneamente, em posição posterior e anterior à base de uma mesma palavra são denominados "circunfixos". O verbo beschönigen (embelezar) ilustra o último caso; os circunfixos "be" e "ig" são incorporados a uma base adjetiva (schön).

\subsubsection{Prefixos}

Vamos nos deter ao estudo dos prefixos, tema de nossa pesquisa. Os prefixos podem acompanhar substantivos, adjetivos ou verbos. Quanto a essas ligações, Donalies (2007) observa: “os prefixos não tem nenhum papel sintático quando combinados com substantivos e adjetivos"19 (DONALIES, 2007 p. 21). Quando associados a verbos, contudo, os prefixos determinam as características gramaticais da palavra, contrariando o princípio Righthand Head Rule, que confere à parte mais à direita de uma palavra complexa as características morfológicas do todo: "a regra da direita é um princípio

\footnotetext{
${ }^{18}$ No original: "vergolden bezeichnet eine durch ver- benannte Tätigkeit, bei der etwas mit Gold versehen wird: die Restaurateure vergolden das Eisengitter." (DONALIES, 2007, p.16)

${ }^{19}$ No original: "In Kombination mit Substantiven und Adjektiven spielen Präfixe syntaktisch keine Rolle." (DONALIES, 2007, p. 21)
} 
geral, no qual palavras complexas herdam suas características morfológicas da parte mais à direita." ${ }^{20}$ (OLSEN, 1991, p. 338 f apud DONALIES, 2007, p. 21).

Os exemplos de compostos ilustram de forma evidente a propriedade mencionada: Em Apfeltorte (torta de maçã) o vocábulo Torte (torta) possui todas as características gramaticais que atribuem a Apfeltorte a categoria de gênero feminino. Portanto, Torte é o "núcleo sintático"21 da palavra.

Não obstante, como mencionado, há construções que configuram exceções à regra citada. Quando o verbo tem sua origem em substantivo ou adjetivo, frequentemente o prefixo desempenha o papel de núcleo sintático, a exemplo de "bedachen" (construir um telhado, cobrir) e "betäuben" (atordoar), cujas raízes são o substantivo "Dach" e o adjetivo "taub" respectivamente. Mas é importante notar que *dachen e *täuben não constituem entradas lexicais. Nos exemplos, é o prefixo be-que provoca a mudança de classe das palavras; ele é responsável por suas caracterizações e, portanto, recebe a denominação de núcleo sintático. Ademais, o prefixo be-, nesses casos, pode ser classificado como "determinado", uma vez que revela propriedades das respectivas raízes; características associadas ao substantivo Dach (telhado) e ao adjetivo taub (surdo), morfemas orientados semanticamente. Assim, em bedachen, o prefixo revela a principal propriedade semântica do substantivo Dach (telhado) ao transformá-lo em verbo, a saber, cobrir determinada área. Da mesma forma, a ação em betäuben é construída pelo prefixo em questão, assimilado ao adjetivo taub (surdo): perder o sentido de audição.

Após identificação das unidades formadoras, é importante conhecer como se dá o processo de formação de palavras propriamente dito. Donalies (2007) enumera para tanto quatro formas de ocorrência: formas combinadas de formação de palavras, formas com modificadores internos de formação de palavras, formas redutoras de formação de palavras e formas associativas. Dentre todas essas, a forma combinada de formação de

\footnotetext{
${ }^{20}$ No original: "Die Righthand Head Rule legt in Form eines allgemeinen Prinzips fest, dass komplexe Wörter ihre morphologischen Eigenschaften vom rechten Bestandteil ererben." (OLSEN, 1991, p. $338 \mathrm{f}$ apud DONALIES, 2007, p. 21).

21 O termo "syntaktischer Kopf" foi traduzido por "núcleo sintático" baseado na terminologia do português brasileiro, uma vez que não há "cabeça sintática". Contudo, as gramáticas alemãs usam também o termo Kern (núcleo) para nomear aquelas unidades que carregam o significado principal do composto. Einsenberg (2006) estabelece a diferença entre os termos Kopf e Kern: "Kerne sind nur solche Einheiten, denen eine nichtleere lexiklische Bedeutung zugeordnet ist, die sog. Autosemantika."
} 
palavras descreve os verbos formados pelo prefixo ver- e será, portanto, analisada detalhadamente neste estudo. Conforme Donalies (2007), tal forma pode ser associada a dois procedimentos: composição e derivação explícita.

\title{
1.1.2.1. Composição
}

Lewandowiski (1990) define composição como a simples ligação de duas ou mais palavras, revelando tratar-se de um dos mais importantes procedimentos de formação de palavras na língua alemã:

\begin{abstract}
"forma de combinação de palavras, no alemão é o procedimento mais usado para formar novas palavras, sendo o modelo estrutural mais importante, ao lado da derivação e prefixação. Ligação de duas ou mais palavras/lexemas..”22. (LEWANDOWISKI, 1990, p. 577)
\end{abstract}

Neste fenômeno, a junção das palavras ou confixos dá origem a um produto denominado composto, cujas partes são classificadas em "determinante"23 (unidade mais à direita) e "determinado" 24 (unidade à esquerda que caracteriza a primeira). $\mathrm{O}$ determinante refere-se à parte principal da palavra, que fundamenta seu sentido como, por exemplo, na palavra Apfeltorte: Eine Apfeltorte ist eine Torte. (Torta de maçã: uma torta de maçã é uma torta). O determinado, por sua vez, delimita semanticamente o restante da palavra. Em Apfeltorte, “Apfel” (maçã) especifica o tipo de torta: de maçã.

Apesar de haver consenso quanto aos processos de formação e terminologias, algumas classificações recebem nomenclaturas diferentes, dependendo do critério adotado pelos autores. Naumann (2000) observa que a formação de palavras é um fenômeno caracterizado principalmente pela combinação de morfemas. Conforme o significado desses, as formações são divididas em: totalmente motivadas (vollmotiviert), parcialmente motivadas (teilmotiviert) e não motivadas (unmotiviert). As motivadas

\footnotetext{
${ }^{22}$ No original: "Art bzw. Form der Wortbildung, Wortzusammensetzung, im Dt. das am häufigsten verwendete Verfahren, neue Wörter zu bilden und das strukturell wichtigste Wortbildungsmodell (nebenAbleitung und Präfixbildung); die Verbindung zweier oder mehrerer Wörter /Lexeme." (LEWANDOWISKI, 1990, pg. 577)

23 "Determinatum"

24 "Determinans"
} 
apresentam os dois ou os demais integrantes com significado pleno para a formação, como em Diskussionsbeitrag (contribuição em uma discussão). As formações parcialmente motivadas apresentam, por outro lado, elementos que não contribuem para o entendimento do vocábulo no seu significado original, como em "Großvater" (avô), substantivo, no qual apenas a raiz "Vater" (pai) remete ao significado do composto. Já nas formações não motivadas nenhuma parte integrante corresponde ou mesmo remete ao significado do conjunto de que faz parte, a exemplo de Hochzeit (casamento) e Augenblick (curto período de tempo, momento).

As diferenças terminológicas apontadas não afetam, contudo, nosso trabalho. Nos compostos determinativos ${ }^{25}$ da língua alemã há uma característica que contribui para nossa pesquisa, conforme Donalies (2007): “eles são estruturados basicamente de forma binária" ${ }^{26}$. Dessa forma, podemos analisá-los a partir da segmentação em duas unidades, independente de quantas palavras há em seu interior:

O princípio binário, princípio da divisibilidade em duas unidades é válido para compostos como Apfel(1) torte(2) assim como para compostos como Apfeltortenrezeptbuchverlagsdirektoren (1) tochter (2). Ambas estruturas ramificadas de compostos determinativos podem ser representadas de forma hierárquica no diagrama de árvore. ${ }^{27}$ (DONALIES, 2007 p. 37)

Nesses termos, podemos aplicar também em múltiplos compostos o princípio binário mencionado, como em "Apfeltorte". Apesar da extensa formação com mais de cinco substantivos aglutinados, o composto "Apfeltortenrezeptbuchverlagsdirektoren tochter" (filha dos diretores da editora do livro de receitas de torta de maçã) citado pela autora pode também ser decomposto em duas partes principais para melhor entendimento de seu significado: "Apfeltortenrezeptbuchverlagsdirektoren" (diretores da editora do livro de receitas de torta de maçã) e "Tochter" (filha). A composição oferece vasta possibilidade de combinações. Além da já citada formação entre dois substantivos (Apfeltorte), podemos identificar outras variantes na língua alemã:

\footnotetext{
${ }^{25}$ Compostos determinativos são aqueles formados por um determinatum e um determinans.

${ }^{26}$ No original: "sie sind grundsätzlich binär strukturiert" (DONALIES, 2007, p. 37).

${ }^{27}$ No original: "Das Prinzip der Binarität, das Prinzip der Teilbarkeit in jeweils zwei Einheiten, gilt für Komposita wie Apfel(1) torte(2) genauso wie für Komposita wie Apfeltortenrezeptbuchverlagsdirektoren (1) tochter (2). Die jeweils binär verzweigte Struktur von Determinativkomposita lässt sich hierarchisch in einem Baumdiagramm darstellen." (DONALIES, 2007, p. 37)
} 
substantivos com adjetivos (Himmelblau) (azul celeste) e verbos junto a adjetivos (trinkfest) (beberrão).

Os compostos determinativos obedecem a um sistema e a certas normas, que nos permitem escolher uma possibilidade de combinação específica e não outra; O sufixo -bar revela-se ainda bastante produtivo quando ligado a bases verbais: "o novo sufixo derivacional especializa-se aos poucos em bases verbais: com isso, no "Frühneuhochdeutsch" (FNHD) ${ }^{28}$, cristaliza-se o novo e produtivo modelo de formação de palavras (verbo + bar). ${ }^{, 29}$ (NÜBLING, 2006 p.75). Atualmente, quando ligado a adjetivos, tal sufixo exemplifica uma formação agramatical. Na publicidade, porém, a palavra "unkaputtbar" (inquebrável) foi criada sem gerar problemas de interpretação: "eine unkaputtbare Colaflasche"30 (DONALIES 2007 p. 59). O sistema, assim, denota regras, com as quais o falante trabalha para formar palavras. A respeito do adjetivo kaputtbar (estragável), Naumann explica:

Em quebras conscientes de regras fica claro que, quando da formação de neologismos, o falante detém-se inconscientemente aos mais diversos campos linguísticos, em normas não codificadas, em restrições fonológicas, morfológicas, semânticas e discursivas. ${ }^{31}$ (NAUMANN, 2000 p.31).

Em comparação às línguas romanas, o alemão não permite a manipulação arbitrária dos termos para a formação de compostos em certos casos. Diferente do italiano, no qual a formação do substantivo dá-se com o verbo conjugado (portalettere), o correspondente no alemão Briefträger (carteiro), não permite a inversão das unidades formadoras com o verbo conjugado no composto (*Trägtbrief), pois constituiria algo problemático e incorreto do ponto de vista semântico (cf. Donalies, 2007, p. 59). Dessa maneira, a norma orienta o indivíduo no exercício de formação de palavras e refere-se a tudo que é aceitável ou tradicional na morfologia.

\footnotetext{
${ }^{28}$ O período equivale ao intervalo entre os anos 1350 e 1650.

29 No original: "Das neue Derivationssuffix spezialisiert sich allmählich auf verbale Basen: Damit kristallisiert sich im Fnhd. das neue, produktive Wortbildungsmuster (Verb + bar) heraus." (NÜBLING, 2006, p.75).

${ }^{30}$ Uma garrafa de Coca Cola inquebrável.

${ }^{31}$ No original: "Derartige bewusste Normenverstöße machen deutlich, dass sich der Sprachbenutzer bei der Bildung von Neologismen unbewusst auf den verschiedenen sprachlichen Ebenen an nicht kodifizierte Normen hält, an phonotaktische, morphologische, semantische und gesprächslogische Restriktionen." (NAUMANN, 2000, p.31).
} 
Outro tipo de composto identificado nas gramáticas são os compostos copulativos, raros e considerados construções exóticas, onde não há relação hierárquica entre os termos formadores. Os exemplos são convencionais e geralmente nomes de Estados ou cidades: Elsaß-Lothringen, Schleswig-Holstein, Österreich-Ungarn etc.

\subsubsection{Derivação explícita}

Para o estudo dos verbos com o prefixo ver- é relevante, contudo, o segundo procedimento da forma combinada, a saber, a derivação explícita. Nesse caso, palavras e confixos são ligados a afixos formadores de palavras, unidades que nos permitem facilmente identificar a derivação explícita. Assim como os compostos determinativos, os derivados explícitos também são binários. A diferença apresenta-se, porém, na estrutura: enquanto naqueles a unidade mais à esquerda delimita a mais à direita, como em Apfeltorte (torta de maçã) nos derivados explícitos tal hierarquia pode ser invertida, a exemplo de Kindchen (criancinha). Quanto à semântica, Donalies (2007) comenta: “o núcleo semântico de derivados explícitos é ora a unidade à esquerda, ora a unidade à direita" ${ }^{32}$.

Os substantivos derivados são classificados de acordo com a classe da palavra usada na formação do vocábulo: derivados de substantivo, de adjetivo, de verbo ou de advérbio. As palavras derivadas de substantivos, a exemplo das prefixais (substantivische Präfixderivate), são capazes de determinar a base da palavra: "Uma megafesta indica uma festa, a saber, uma grande, notável e marcante festa." 33 (DONALIES, p. 70). Há também aqueles com a qualidade diminutiva, uma derivação sufixal substantiva com sufixos capazes de diminuir, minimizar a importância do sujeito ou coisa, à qual se referem: Elefäntlein (elefantezinho), Mäuschen (ratinho). Na língua alemã, a qualidade diminutiva é geralmente marcada com o uso dos sufixos -chen e lein.

\footnotetext{
${ }^{32}$ No original: "Der semantische Kopf von expliziten Derivaten ist also mal die linke, mal die rechte Einheit." (DONALIES, 2007, p. 69).

${ }^{33}$ No original: "so bezeichnet Megaparty eine Party, und zwar eine besonders große, eine großartige, herausragende." (DONALIES, 2007, p. 70).
} 
Os adjetivos derivados também comportam uma rica variedade de construções, conforme as unidades formadoras e suas respectivas qualidades: negativa com o uso de prefixos (anormal, asozial, unfreundlich, etc. $)^{34}$, potencial $^{35}$ pelo uso do sufixo -bar (brennbar, verwundbar, etc) ${ }^{36}$, diminutiva com o sufixo -lich (gelblich, bläulich, etc) ${ }^{37}$, entre outras.

Dentre todas as formas derivadas, as verbais constituem as mais importantes para nossa pesquisa. Os verbos derivados podem ser construídos a partir de substantivos, adjetivos, os próprios verbos e os chamados confixos verbalizados. Donalies (2007) afirma ser a derivação prefixal verbal especialmente produtiva e observa que alguns prefixos são específicos para a formação de verbos: be-, ent-, er-, ver- e zer-. Tais prefixos são morfemas constituintes dos chamados verbos não separáveis (untrennbare Verben). Dentre esses, apenas be-, er-, ver- e zer- ainda podem ser considerados produtivos na língua alemã. Naumann comenta a função dos prefixos:

Os prefixos têm a função de diferenciar semanticamente verbos prefixais daqueles de mesma base sem o prefixo. Assim, formam-se pares como hören vs. erhören, greifen vs. begreifen, täuschen vs. enttäuschen, machen vs. vermachen. ${ }^{38}$ (NAUMANN, 2000 p. 57)

Nos exemplos citados, há pouca ou nenhuma relação semântica entre o verbo original e seu correspondente prefixal. Contudo, é possível notar, em certos casos, algum traço semântico nos prefixos, como em arbeiten vs. erarbeiten ${ }^{39}$, grauen vs. ergrauen $^{40}$, grünen vs. ergrünen ${ }^{41}$. Nesses verbos, o prefixo er- tem conotação resultativa. Percebe-se, portanto, que uma avaliação quanto ao significado é inevitável. Donalies (2007) chega até mesmo a categorizar os derivados conforme as funções desempenhadas pelos prefixos. A autora encontra seis acepções que os prefixos podem

\footnotetext{
${ }^{34}$ Anormal, não social, não amigável, etc.

35 potenzialia (DONALIES, 2007, p. 81)

36 Inflamável, vulnerável, etc.

${ }^{37}$ Amarelado, azulado, etc.

38 No original: "Präfixe haben die Funktion, präfigiertes Verb und das dazugehörende Simplex semantisch zu differenzieren. Es entstehen also Paare wie hören vs. erhören, greifen vs. begreifen, täuschen vs. enttäuschen machen vs. vermachen..." (NAUMANN, 2000, p. 57)

${ }^{39}$ Trabalhar vs. conquistar.

${ }^{40}$ Abater-se vs. acinzentar (tornar grisalho).

41 Tornar verde vs. esverdear.
} 
transmitir, a saber: "Ornativa", "Privativa", "Instrumentiva”, "Vergleich", "Faktitiva", "räumliche Gerichtetheit", "Inchoativa Perfektiva" e "Negativa Falsifikativa".

Alguns prefixos transmitem qualidades quando combinados a certas classes de palavras, como substantivos ou adjetivos. Tais prefixos possuem a função "Ornativa” eles cedem características aos núcleos, aos quais são ligados: vergolden (banhar a ouro), erfrischen (refrescar), beengen (restringir). Nesses casos, os prefixos verbalizam uma qualidade: transformam em ação um substantivo ou um adjetivo com a marca da verbalização, o sufixo -en.

Ao contrário da anterior, a característica "Privativa", concede ao núcleo a ideia de subtração, privação. O mais emblemático dos prefixos capazes de imprimir tal valor é o ent-, como em entblättern (desfolhar), entvölkern (dizimar, diminuir a população).

A função Instrumentiva designa o instrumento utilizado na ação, como indicam os verbos: befingern (cutucar com as pontas dos dedos), beäugen (observar, contemplar), erdolchen (apunhalar), entre outros. Em alguns casos, o prefixo chega a ser desnecessário para exprimir tal instrumentalização, a exemplo de pinseln (pincelar, borrar). Nesse último, há apenas o acréscimo do sufixo $-n$ ao núcleo.

Para Vergleich, Donalies (2007) atribui o efeito da comparação, como a própria tradução evidencia para o exemplo sich ermannen: "quem se encoraja, comporta-se com coragem feito um homem"42 (DONALIES, 2007 p. 85).

A propriedade Faktitiva permite ao leitor identificar uma transformação em algo ou alguém; conforme sugerido nos vocábulos verfilmen (filmar), versumpfen (atolar-se, corromper-se), vertonen (musicalizar), entre outros. Nota-se nesses casos a neutralidade do prefixo ver-; nos verbos mencionados, ele apenas verbaliza os núcleos substantivos e não apresenta aspecto negativo.

Alguns prefixos são usados ainda para transmitir noção espacial de direcionamento (räumliche Gerichtetheit), a exemplo de beschnüffeln (farejar),

\footnotetext{
${ }^{42}$ No original: "wer sich ermannt, verhält sich mutig wie ein Mann" (DONALIES, 2007, p. 85).
} 
devidamente explicado: "ein Hund, der eine Wurst beschnüffelt, schnüffelt an einer Wurst." ${ }^{43}$ (DONALIES, 2007 p. 85).

A noção de princípio pode ser percebida em verbos, cujos prefixos indicam a propriedade Inchoativa Perfektiva: erblühen (florecer), erstrahlen (irradiar) (DONALIES, 2007, p. 86). Da mesma forma, o fim pode ser expresso por ver-: verblühen (murchar), mas Donalies não chega a categorizar separadamente tal marcação.

Donalies (2007) identifica por último a qualidade Negativa Falsifikativa, desempenhada principalmente por dois prefixos: miss- e ver-. Dependendo do verbo ao qual são combinados, eles podem sugerir negação ou erro; negação como no período "Wer einen weisen Rat missachtet, achtet ihn nicht."44 ou erro em "wer eine Situation missdeutet, deutet sie falsch." 45 (DONALIES, 2007 p. 86). Entretanto, atribuir, aleatoriamente, apenas conotação negativa ao prefixo ver- é um erro, como demonstrado ao longo deste trabalho. Em verbos como verflüssigen (diluir, condensar) (conotação neutra), verbessern (melhorar) (conotação positiva) e verarmen (empobrecer) (conotação negativa) as qualidades, explicitadas entre parênteses, são inerentes aos adjetivos usados: flüssig (líquido), besser (melhor) e arm (pobre) respectivamente.

A atribuição de valores semânticos aos prefixos é ponto comum entre pesquisadores. A esse respeito, Fleischer (1967) comenta: Os prefixos “... mostram também que não é possível uma interpretação unívoca sem levar em consideração a semântica. ${ }^{״ 46}$ Entretanto, não há consenso quanto à classificação dos grupos. O prefixo ver- também é alvo de observações por parte do autor, que discrimina os seguintes grupos gerais de significado, conforme ideia central dos verbos: ornativo [verglasen (colocar vidro), -golden (banhar a ouro), -zuckern (açucarar)], fora do caminho correto [verhören (escutar mal), verlesen (cometer erro quando da leitura de algo), -rechnen (cometer erro no cálculo de uma conta), -schreiben (cometer erro na escrita despropositadamente)], contrário [verachten (menosprezar) -lernen (desaprender)],

\footnotetext{
${ }^{43}$ Um cão, que fareja uma salsicha, fareja uma salsicha.

${ }^{44}$ Quem ignora um conselho, não presta atenção nele.

${ }^{45}$ Quem entende mal uma situação, interpreta-a mal.

46 No original: "Sie zeigen auch, dass ohne Berücksichtigung der Semantik keine einwandfreie Interpretation möglich ist." (FLEISCHER, 1967, p. 10)
} 
eliminação [verjubeln (desperdiçar) -tanzen (errar passo na dança), -trinken (gastar todo o dinheiro em bebida)] e finalização [verklingen (diminuir o volume do som) - löschen (vela, fogo apagar-se)] (FLEISCHER, 1967, p. 10).

A falta de padronização quanto às acepções que os prefixos podem assumir é evidenciada pelos diferentes termos usados pelos autores. Tal fato revela o quão diverso ou incerto seja o campo da semântica dos prefixos. Reconhecemos, ao mesmo tempo, o perigo em sugerir determinados significados na imensidão de possibilidades de interpretação, sob o risco de análises simplistas. Diante da regularidade na construção dos derivados explícitos, foi possível refazer o percurso de formação dos neologismos encontrados nas letras de música, e assim, sugerir valores semânticos ao prefixo ver-, adiante, no capítulo quatro, denominado "análise dos verbos".

\section{2- Princípios e conceitos da teoria da gramática de construções}

\subsubsection{Relevância para a análise do objeto de pesquisa}

Em consonância com meu objetivo central nesta dissertação, de conhecer a função semântica desempenhada pelo prefixo ver- em novas formações verbais, descrevo neste capítulo a versão proposta por Goldberg (1995) da teoria da gramática de construções, cujos princípios e conceitos serviram de norteadores para este estudo. Como veremos, os verbos constituídos pelo prefixo ver- podem ser classificados como construções, uma vez que apresentam equivalências estruturais e semânticas. Tal constatação tem implicações diretas no tratamento dado à interpretação do papel semântico conferido aos prefixos na língua alemã. Ademais, esperamos que este seja, futuramente, o embrião de um projeto maior direcionado ao ensino da língua alemã como língua estrangeira.

Dessa forma, a importância deste estudo pode ser verificada na medida em que seus resultados constituem evidências de aplicação dos modelos teóricos de orientação funcionalista-cognitivista, como a versão proposta por Goldberg (1995).

De maneira esquemática e na esperança de que sejam genéricas, as teorias gramaticais tentam construir modelos de representação de como o léxico e/ou a sintaxe são organizados na mente humana. Trata-se de tentativas de buscar explicação sobre o 
conhecimento abstrato que temos sobre língua e linguagem. Nos estudos de gramática tradicional, diversos autores propuseram modelos e classificaram estruturas que fazem parte do que é considerado nuclear na gramática; o restante seria considerado exceção, sem possibilidade de sistematização. Teóricos da Gramática das Construções realizaram o caminho inverso; a proposta é que exatamente essas estruturas, que não são casos típicos, poderiam ser a explicação para o funcionamento da gramática no imenso inventário linguístico humano:

\begin{abstract}
"esse interesse surge da crença de que percepções fundamentais podem ser adquiridas considerando tais casos não centrais, nos quais o maquinário teórico, que explica os casos não centrais, pode ser usado para explicar os casos nucleares." ${ }^{47}$ (GOLDBERG, 1995, p.6)
\end{abstract}

Essas estruturas não nucleares deram origem ao termo construções, uma vez que possuem uma estrutura fixa e um significado. Segundo Goldberg (1995), construções são unidades básicas de uma língua:

C é uma construção se, e somente se, C for um par forma-significado $<\mathrm{Fi}$, $\mathrm{Si}>$ de forma que aspectos de $\mathrm{Fi}$ ou de $\mathrm{Si}$ não sejam estritamente previsíveis de uma parte ou de outras construções pré-existentes. ${ }^{48}$ (GOLDBERG, 1995, p.4).

Apesar de grande parte dos estudos contemplar expressões ditransitivas do inglês como modelo canônico de análises ${ }^{49}$, o termo "construção", não se restringe a essas orações fixas da língua; seu conceito envolve também unidades menores, como os morfemas: "O conceito de construção compreende derivações e flexões morfológicas, por exemplo: [ver-V] / DISTRIBUTIVO (vergeben, verschicken, verschütten, verstreuen, verteilen) ou [N-e]/ PLURAL." ${ }^{50}$ (FISCHER \& STEFANOWITSCH, 2006 p.6). Essa concepção encontra respaldo nos estudos de Saussure: "morfemas são claras instâncias de construções, pois são pares de forma e significado não previsíveis de

\footnotetext{
47 No original: "This interest stems from the belief that fundamental insights can be gained from considering such non-core cases, in that theoretical machinery that accounts for non-core cases can be used to account for core cases." (GOLDBERG, 1995, p.6)

${ }^{48}$ No original: " $C$ is a construction iff $f_{\text {def }} C$ is a form-meaning pair $\left\langle F_{i}, S_{i}\right\rangle$ such that some aspect of $F_{i}$ or some aspect of $S_{i}$ is not strictly predictable from a $C$ 's component parts or from other previously established constructions." (GOLDBERG, 1995, p.4).

${ }^{49}$ Para exemplos consultar Goldberg (1995).

${ }^{50}$ No original: “der Konstruktionsbegriff umfasst Derivations- und Flexionsmorphologie, z. B. [ver-V]/ DISTRIBUTIV (vergeben, verschicken, verschütten, verstreuen, verteilen) oder [N-e]/ PLURAL.” (FISCHER \& STEFANOWITSCH, 2006, p.6)
} 
qualquer outra coisa." (SAUSSURE 1916 apud GOLDBERG, 1995, p.4) ${ }^{51}$. A inclusão de morfemas nas descrições conceituais da teoria possibilitou-nos aprofundar o estudo dos verbos formados com o prefixo ver- na língua alemã sob a ótica da teoria da gramática de construções.

Antes de conhecer os exemplos detalhadamente, vamos descrever as vertentes teóricas existentes. A teoria da Gramática das Contruções é proposta em três perspectivas, de acordo com Fischer (2006): 1- Gramática das Contruções (CG) a partir de Kay e Fillmore (1999), baseado no modelo não derivacional da gramática gerativa. 2- Gramática das Contruções proposta por Lakoff (1987) e Goldberg (1995); corrente baseada na linguística cognitiva e orientada por princípios da semântica de frames, bem como pelas teorias da gramática cognitiva de Langacker $(1987,1991)$ e 3- Gramática radical de construções como proposta por Croft (2001), bastante próxima à gramática cognitiva de Langacker (1987), mas com diferenças quanto ao estudo nas comparações entre línguas.

O modelo proposto por Langacker não considera as unidades simples como construções, a exemplo dos verbos, e por esse motivo não foi considerado no estudo. A versão de Croft não contempla o modelo de herança sugerido pelas outras correntes, que adotamos na análise e por isso, também não contribuiu para a presente pesquisa. Portanto, para este trabalho vamos seguir a linha teórica adotada por Goldberg, sem excluir possíveis contribuições de outros autores. Tal escolha justifica-se pela interpretação sobre a semântica das construções, baseada em uma rede polissêmica e, também, da descrição do modelo de herança, que procura mostrar como as construções adquirem os significados de outras já existentes. Antes de desenvolver a teoria, apresentamos alguns conceitos da linguística cognitiva (Lakoff, 1987), adotados por Goldberg em seu modelo de gramática de construções, conforme Bellavia (2007, p. 80):

1- $\quad$ O indivíduo e sua interação com o meio ambiente estão no cerne da questão da interpretação do significado e da língua. O comportamento corporal e sua interação com o mundo são referências para as relações simbólicas.

\footnotetext{
${ }^{51}$ No original: "morphemes are clear instances of constructions in that they are pairings of meaning and form that are not predictable from anything else" (SAUSSURE, 1916 apud GOLDBERG, 1995, p. 4)
} 
2- Metonímia e metáfora são processos cognitivos que representam ferramentas que permitem a passagem de conceitos espaciais para outras conceitualizações.

3- Conceitos como "protótipo" e "nível básico" desempenham importante papel no pensar e no falar.

4- A polissemia pode ser mais bem representada através de uma estrutura radial ao apresentar os diversos significados que uma palavra possui.

5- Devido à importância da polissemia, deve-se concentrar a atenção não somente nas expressões espaciais como também em frases de sentido metafórico.

Ainda que algumas dessas características sejam mais relevantes que outras, veremos, conforme o desenvolvimento da pesquisa, como tais princípios influenciaram a concepção de construções segundo Goldberg (1995). As três versões da Gramática das Contruções diferenciam-se nas ênfases teóricas e na formulação de modelos para explicar os casos, mas compartilham de princípios fundamentais, que outras teorias gramaticais não mencionam, a saber:

- A estrutura de uma língua pode ser descrita em pares de significado e forma, denominados construções. Assim, léxico e gramática apresentam-se num contínuo.

- Os pares formam um inventário estruturado.

- Gramática não é modular e não é derivacional.

- Não há conhecimento linguístico inato.

Para demonstrar como léxico e gramática encontram-se num contínuo, Goldberg analisa construções ditransitivas no inglês, cujos verbos, a princípio, não exigem mais que um complemento. Quando essas construções são propostas com mais de um complemento verbal, há divergências entre os autores que adotam regras lexicais daqueles que preferem uma abordagem construcionista. Como exemplo, Goldberg identifica problemas na interpretação lexical sugerida em "She baked him a cake"52. Para a referida sentença, a abordagem lexical propõe um sentido especial para o verbo

\footnotetext{
${ }^{52}$ Ela fez um bolo para ele.
} 
"bake", admitindo a existência de três argumentos, a saber, um agente, um tema e um recipiente intencional (Goldberg, 1995). Entretanto, na visão construcionista, podemos interpretar o fenômeno de outra forma: não há necessidade de determinarmos quantos argumentos um verbo apresenta. Segundo Boas (2008 p. 119): “o significado de uma construção é codificado em termos de relações estabelecidas entre seus papéis semânticos abstratos, também conhecidos como papéis argumentais (tipos representativos de eventos)" ${ }^{, 53}$. Goldberg acrescenta que a própria construção pode "ser associada diretamente com papéis de agente, paciente e recipiente, e então associar a classe de verbos de criação com a construção ditransitiva." ${ }^{54}$ (GOLDBERG 1995, p.10). A representação de categorias através de classes e subclasses tem sua origem na ciência da computação. Os linguistas também aproveitaram dessa estratégia para esquematizar eventos e ações humanas, o que possibilitou investigar a linguagem de forma mais detalhada.

Uma propriedade chamada motivação é a explicação para que determinadas sentenças sejam alocadas em certas classes de oração. Conforme Croft (2004), as construções não estão dispostas de forma aleatória em uma lista no vasto campo de conhecimento do falante; elas encontram-se ligadas em uma rede taxonômica, onde cada uma corresponde a um nódulo. Os teóricos construcionistas consideram que as construções podem ser representadas de maneira esquemática e essa representação é denominada motivação: "uma dada construção é motivada no momento em que sua estrutura é herdada de outra construção da língua." 55 (Lakoff apud Goldberg, 1995 p. 70). Para tanto, os autores mencionam o fenômeno da herança, termo emprestado também da ciência da computação, cuja função é demonstrar, como e por quê um objeto (em nosso caso, um verbo) pode ser associado a determinado grupo e classificado como tal. A esse respeito, Croft comenta: "a construção nos níveis taxonômicos mais baixos herdará essa propriedade em virtude de ser uma instância da construção [Verbo Obj]." ${ }^{\text {,6 }}$ (CROFT, 2004 p. 270). Dessa forma, é possível identificar como alguns elementos ou

\footnotetext{
${ }^{53}$ No original: "The meaning of a construction is encoded in terms of relationships holding between its abstract semantic roles, also known as argument roles (representing event types)." (BOAS, 2008, p. 119) ${ }^{54}$ No original: "We can define the ditransitive construction to be associated directly with agent, patient, and recipient roles, and then associate the class of verbs of creation with the ditransitive construction." (GOLDBERG 1995, p.10)

${ }^{55}$ No original: "A given construction is motivated to the degree that its structure is inherited from other construction in the language." (LAKOFF apud GOLDBERG, 1995 p. 70).

${ }^{56}$ No original: "The construction at the lower taxonomic levels will then inherit this property by virtue of being an instance of (an instance of) the [Verb Obj] construction." (CROFT, 2004 p. 270).
} 
características estão presentes em estruturas, de morfemas a orações: eles são herdados por laços de instância de classes superiores, nas quais as estruturas estão alocadas. Segundo Goldberg, "Determinados itens lexicais que só ocorrem em construções particulares são instanciações daquela construção, uma vez que herdam lexicalmente a sintaxe e a semântica associadas à construção."57 (GOLDBERG, 1995 p. 79). Além dos laços de instância, a autora postula a existência de mais três tipos de relações de herança, a saber: laços subparte, laços polissêmicos e laços por extensão metafórica (GOLDBERG, 1995 p. 75). Neste estudo, vamos nos ater também aos laços polissêmicos.

Em consonância com os princípios da linguística cognitiva, Goldberg estabelece a hipótese de cena codificada: "construções que correspondem a tipos de sentenças básicas codificam como sentidos centrais os tipos de eventos que são básicos para a experiência humana."58 (GOLDBERG, 1995, p.39). Os sentidos centrais, termo mencionado na passagem, têm origem na concepção de polissemia, que admite a existência de interpretações semanticamente próximas a um significado central de um vocábulo. O fenômeno não está restrito às palavras, ele pode ser observado também no âmbito das construções.

Como consequência tem-se que, sob a ótica construcionista, não é necessário atribuir diversos significados a um verbo ou apontar suas especificidades em uma determinada construção. Em sentenças como "Maria fez um bolo para o João" (adaptado de Golberg, 1995), não significa necessariamente que João tenha recebido o bolo. Por essa razão, em expressões com verbos de criação como "fazer", "cozinhar", “construir”, etc. não significa que o beneficiário da ação receba algo/paciente. Dessa forma, admite-se um sentido básico para expressões desse tipo (ditransitivas), nesse caso, "transferência bem sucedida". Como podemos notar, as diferenças de interpretação fazem surgir nuances de significado, também possíveis nas formas ditransitivas e que, para Goldberg, são associadas a um conjunto de sentidos relacionados sistematicamente. Por essa razão, elas podem ser consideradas construções polissêmicas:

\footnotetext{
${ }^{57}$ No original: "Particular lexical items which only occur in a particular construction are instances of that construction, since they lexically inherit the syntax and the semantics associated with the construction.” (GOLDBERG, 1995 p. 79)

${ }^{58}$ No original: "Constructions which correspond to basic sentence types encode as their central senses event types that are basic to human experience." (GOLDBERG, 1995, p.39).
} 
A mesma forma é construída com sentidos diferentes, porém relacionados. Levando-se em consideração essas diferenças em termos de polissemia construcional, ao invés de postular uma coleção de regras lexicais, por exemplo, podemos captar as relações entre os diferentes sentidos de forma natural. Em particular, uma análise polissêmica permite-nos reconhecer o estado especial do sentido central da construção. ${ }^{59}$ (GOLDBERG, 1995 p. $33)$.

Uma vez que não se pode prever que todos os verbos com sentido de criação sejam permitidos nas construções ditransitivas, a autora sugere uma rede de sentidos relacionados à construção em questão. Ainda quanto ao tema "polissemia", Croft chama a atenção para uma característica do arranjo de sentidos: "a mais importante propriedade da análise polissêmica é que o sentido de uma construção é central e outro é uma extensão disso." ${ }^{, 60}$ (CROFT, 2004 p. 275). Assim, a relação de uma construção de sentido periférico e seu sentido central é determinada por laços polissêmicos de herança, ou seja, as extensões de significado devem-se aos laços de herança estabelecidos com a construção de sentido central.

A polissemia também pode ser observada nas construções com o prefixo ver-, devido a uma característica intrínseca ao prefixo em questão, a saber, suas diferentes acepções nos derivados em que está presente, conforme DUDEN online ${ }^{61}$. Para ilustrar as acepções, o dicionário exibe alguns exemplos de verbos, nos quais se pode observar as características mencionadas nas acepções. Não obstante, alguns verbos citados nos itens não apresentam uma tradução direta para o português e nem o próprio DUDEN explica-os, a exemplo de verforschen, verfrühstücken e vercomputerisieren. Dessa forma, para descrevê-los, bem como para estabelecer relações com as respectivas descrições, recorremos à paráfrase.

A busca por "ver" no campo "buscar", no endereço eletrônico mencionado, exibe os significados conforme a classe morfológica da raiz à qual se liga. Assim, o prefixo expressa, em formações com substantivos ou adjetivos e uma desinência,

\footnotetext{
59 No original: "The same form is paired with different but related senses. By accounting for these differences in terms of constructional polysemy, as opposed to positing a collection of lexical rules, for example, we can capture the relations between the different senses in a natural way. In particular, a polysemous analysis allows us to recognize the special status of the central sense of the construction." (GOLDBERG, 1995, p. 33).

${ }^{60}$ No original: "the most important property of the polysemy analysis is that one construction sense is central and another is an extension from it." (CROFT, 2004, p. 275).

${ }^{61}$ www.duden.de. Os acessos deram-se frequentemente ao longo da execução do trabalho, sendo difícil determinar as datas.
} 
A) que uma pessoa ou coisa (no decorrer de um tempo) modifica-se em algo (denominado pelo substantivo ou pelo adjetivo) ${ }^{62}$. Ex: verarmen (empobrecer), verdorfen (a cidade encolhe por evasão dos habitantes), verprovinzialisieren (tornar-se provinciana).

B) que uma pessoa ou coisa é convertida em algo, deslocado para um determinado estado. ${ }^{63}$ Ex: vereindeutigen (pormenorizar, especificar), verfeaturen, (caracterizar, tornar algo mais atraente), vermodernisieren (dar cara nova, repaginar).

O prefixo expressa, ainda, em formações com substantivos e uma desinência,

C) que uma pessoa ou coisa é provida com outra. ${ }^{64}$ Ex: vercomputerisieren (digitalizar), verschorfen (cobrir com crosta / casca).

E também expressa, em formações com verbos,

D) que uma coisa é eliminada por algo (uma ação), está gasta, não presta mais. ${ }^{65}$ Ex: verforschen (pesquisa que não dá resultado algum ou que se constitui um descaminho, desperdício). verfrühstücken, (ações que prejudicam a pessoa no futuro, desperdiçar oportunidades), verwarten (esperar sem ter resultado).

E) que uma pessoa passa o tempo com algo. ${ }^{66}$ Ex: verschlafen (passar o tempo dormindo/perder a hora), verschnarchen (passar o tempo roncando), verspielen (passar o tempo jogando / perder algo no jogo).

F) que uma pessoa faz algo errado, às avessas. ${ }^{67}$ Ex: verbremsen (se enganar e frear na hora errada), verinszenieren. (encenar/dirigir uma peça de forma que não agrada).

\footnotetext{
${ }^{62}$ No original: drückt in Bildungen mit Substantiven oder Adjektiven und einer Endung aus, dass sich eine Person oder Sache [im Laufe der Zeit] zu etwas (was im Substantiv oder Adjektiv genannt wird) hin verändert.

${ }^{63}$ No original: drückt in Bildungen mit Substantiven oder Adjektiven und einer Endung aus, dass eine Person oder Sache zu etwas gemacht, in einen bestimmten Zustand versetzt, in etwas umgesetzt wird.

${ }^{64}$ No original: drückt in Bildungen mit Substantiven und einer Endung aus, dass eine Person oder Sache mit etwas versehen wird.

${ }^{65}$ No original: drückt in Bildungen mit Verben aus, dass eine Sache durch etwas (ein Tun) beseitigt, verbraucht wird, nicht mehr besteht.

${ }^{66}$ No original: drückt in Bildungen mit Verben aus, dass eine Person mit etwas ihre Zeit verbringt.

${ }^{67}$ No original: drückt in Bildungen mit Verben aus, dass eine Person etwas falsch, verkehrt macht.
} 
G) que uma coisa é prejudicada por algo. ${ }^{68}$ Ex: verwaschen (desbotar / perder a cor pela constante lavagem), verwohnen (desgastar pelo uso, sem cuidado, desleixo e abandono).

H) que ele não influencia no significado do verbo base que o acompanha. ${ }^{69}$ Ex: verbleiben (permanecer no compromisso, não alterá-lo), verbringen. (passar um tempo).

Como mencionado anteriormente, a paráfrase foi o recurso usado para descrever alguns exemplos que o dicionário oferece, mas que não explica. Assim, em uma ferramenta de busca na internet ${ }^{70}$, procuramos contextos que citassem os termos em questão. O verbo verfrühstücken, por exemplo, foi encontrado em um fórum de discussão virtual, cujo título anunciava: “Merkel-Regierung: Zukunft verfrühstückt." Na frase, o verbo sinaliza ações que a chanceler alemã Angela Merkel havia tomado e que certamente prejudicariam sua reeleição no futuro. Um dos sujeitos lembra conhecer outro sentido para o verbo em questão: "Só conheço o uso ‘jocoso' de 'verfrühstücken', tipo: 'Er hat sein Vermögen verfrühstückt.' = ele gastou tudo que tem de forma leviana, 'numa boa', como se fosse num café da manhã...'. Assim, para a descrição proposta, ambos os significados foram considerados. Para o verbo vercomputerisieren foi proposta a tradução "digitalizar" devido ao contexto em que o verbo foi encontrado: "Video ist auf der analogen Kasette, bin leider zu doof das zu vercomputerisieren"71. Diferente de todas as demais, a última acepção exibe exemplos de verbos, cujas raízes em nada lembram o significado do conjunto; assim bringen (trazer) não tem ligação semântica alguma com verbringen (passar o tempo).

Outros trabalhos (LEOPOLD, 1907; NAUMANN, 2000; EINSENBERG, 2006) também descrevem a variedade de sentidos que as construções com o prefixo verpodem apresentar. Além das publicações citadas, o IDS (Institut für deutsche Sprache) oferece em plataforma virtual o dicionário gramatical ${ }^{72}$, onde foi possível encontrar três sentidos prototípicos que o prefixo pode assumir. Contudo, sua descrição é generalista demais para nossos propósitos. Dessa forma, adotamos a explicação disponível no dicionário DUDEN. A escolha justifica-se por esse ser um dos mais importantes

\footnotetext{
${ }^{68}$ No original: drückt in Bildungen mit Verben aus, dass eine Sache durch etwas beeinträchtigt wird.

${ }^{69}$ No original: hat in Bildungen mit Verben keinen Einfluss auf deren Bedeutung.

${ }^{70}$ www.google.com. Acesso em 15/10/2012.

71 Disponível em http://www.agrar.de/pferde/forum/index.php?topic=27513.215;imode

${ }^{72}$ http://hypermedia.ids-mannheim.de/call/public/gramwb.ansicht
} 
dicionários monolíngues da língua alemã, além da frequente atualização de seus registros $^{73}$. Estamos cientes das limitações a que um estudo baseado em classificações está sujeito, uma vez que há a possibilidade de nos depararmos com casos sem uma categoria que os descreva corretamente ou, então, com diferenças pouco claras para uma devida caracterização. Dessa forma, nem mesmo a proposta do DUDEN está isenta de falhas: o verbo verwarten, por exemplo, está alocado na quarta acepção, cuja qualidade é expressa como "uma coisa é eliminada por algo (uma ação), está gasta, não presta mais". Mas, seria mesmo essa, a melhor categorização para verwarten? Conforme a tradução proposta, o verbo indica uma longa espera sem resultados - uma possível paráfrase para tal descrição seria wartend verbringen ${ }^{74}$. O verbo verbringen também é usado para explicar determinados termos, como estratégia parafrástica, nos verbos do grupo E: verschlafen - schlafend verbringen, verschnarchen - schnarchend verbringen, verspielen - spielend verbringen. Consideramos que verwarten possui as mesmas características que os verbos desse grupo, e por isso, sugerimos sua classificação nessa acepção, reforçada pelo sentido de 'esperar em vão'

Neste trabalho, assumimos que a descrição do verbete constitui um mapeamento dos significados das construções com o prefixo ver- e, além disso, que o primeiro dos significados elencado configura-se como o mais básico de todos. Para as construções, há de se perguntar se há alguma relação entre elas. Tal questionamento é de especial importância para o estudo, na medida em que procuramos entender a qual recurso o falante recorre quando do uso do prefixo na formação de novos verbos. Nossa hipótese é a de que o falante, de alguma forma, recupera tais significados e associa-os aos diferentes usos de ver-, como qualidades próprias das construções que o prefixo forma. Ademais, todas essas formas parecem estar conectadas umas às outras, formando uma rede de significados. Segundo a teoria da gramática de construções, não apenas as partes constituintes de uma construção encontram-se relacionadas, como também as construções entre si:

\footnotetext{
73 Conforme especificado no sítio www.duden.de em "regras gerais de uso" (Allgemeine Nutzungsbedingungen): "Die Webseiten werden in der Regel in bestimmten Abständen aktualisiert, ein Anspruch auf eine Aktualisierung besteht für den Nutzer indes nicht."

${ }^{74}$ A existência desse sintagma pode ser aferida com uma busca na internet, que oferece, entre outros, o seguinte exemplo: "Am Handy unterwegs ist der Konsum hingegen egal, weil man beispielsweise die Zeit in der Straßenbahn sowieso wartend verbringen muss." (http://www.efge.at/zeitfresser-facebook. Acesso em 20/10/2012)
} 


\begin{abstract}
"Enquanto os falantes não podem prever se, ou em que medida, dois conceitos serão relacionados formalmente, afirma-se, contudo, que eles procuram por tais relações para os inputs 'fazerem sentidos', adequando as novas formas na rede de construções inter-relacionadas, que constituem seu conhecimento de língua."75 (GOLDBERG, 1995, p. 71)
\end{abstract}

Dessa maneira, algumas construções estão ligadas a outras por similaridades semânticas atribuídas ao prefixo. Assim, idealizamos o quadro abaixo tendo por base as acepções que o prefixo ver- assume, conforme descrição do dicionário DUDEN online. Entendemos que a primeira descrição do verbete no dicionário seja a de sentido mais comum, a saber, de "modificação":

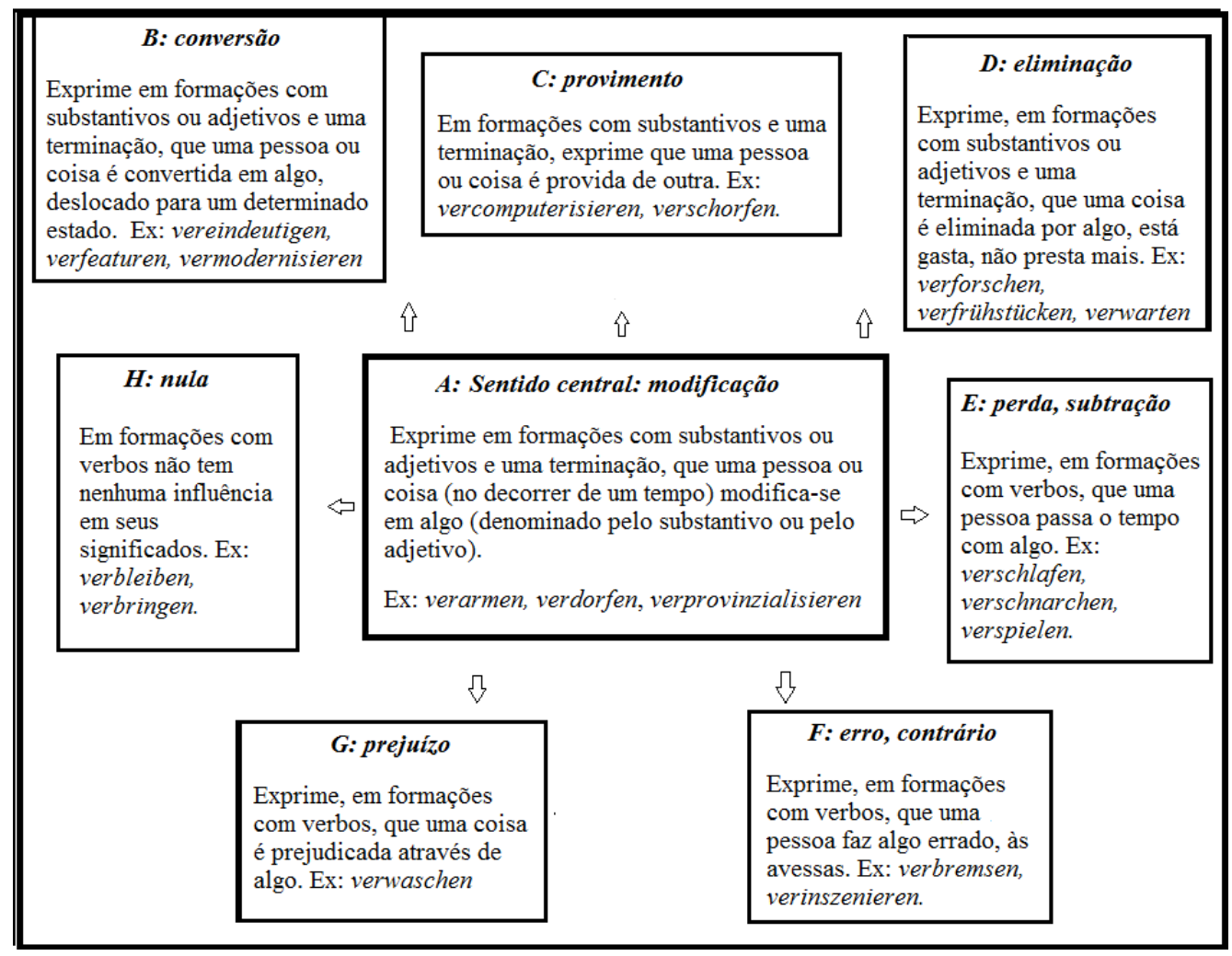

Figura 1: Rede polissêmica de ver-

Segundo o dicionário Langenscheidt, o prefixo ver- é, ainda hoje, bastante produtivo. Tomando a afirmativa como verdade e considerando o caráter polissêmico

\footnotetext{
75 No original: "While speakers cannot predict whether or to what extent two related concepts will be related formally, it is claimed that they nonetheless search for such relations in order to 'make sense of' the input forms, fitting the new forms into the network of interrelated constructions that constitutes their knowledge of language." (GOLDBERG, 1995, p. 71).
} 
das construções com esse prefixo, procuramos neologismos da língua que pudessem recuperar o processo percorrido pelo falante nativo quando do uso do ver-. Como o objetivo do trabalho é descrever verbos com o prefixo ver- não dicionarizados, buscamos interpretações a partir dos contextos para sugerir um sentido para cada um e verificar se, e em qual das acepções estabelecidas por DUDEN, o verbo se encaixaria.

Mas será que podemos relacionar, de fato, os neologismos encontrados à rede de construções formada pelo prefixo ver-? Para responder a essa pergunta, retomamos um dos princípios que rege a organização linguística para os teóricos funcionalistas, a saber, o princípio da Motivação Maximizada (GOLDBERG, 1995, p. 67): "Se a construção A é relacionada sintaticamente à construção $\mathrm{B}$, então o sistema da construção $\mathrm{A}$ é motivado a tal nível que ele é relacionado à construção B semanticamente." ${ }^{\text {76 }}$ Isso significa que se encontrarmos um verbo com a mesma origem derivacional, ou seja, a mesma estrutura sintática de outro indicado no quadro, então eles serão motivados semantica ou pragmaticamente. Assim, os padrões construcionais existentes na língua mostram-se como uma ferramenta facilitadora para o falante, como observa Booij:

\begin{abstract}
A ideia de um léxico hierarquizado também está de acordo com a consideração acima de que as pessoas adquirem um sistema morfológico da língua, ou seja, os esquemas morfológicos abstratos, na base de seus conhecimentos de certa quantidade de palavras que são instâncias desses modelos. Uma vez que eles tenham passado por um número suficiente de palavras de determinado tipo, eles podem inferir um esquema abstrato, e estarão aptos a expandir a classe de palavras. Isso significa que a competência de criar novos compostos e palavras derivadas do nativo é baseada em abstrações de palavras complexas já existentes e em palavras que estão paradigmaticamente relacionadas a elas. ${ }^{77}$ (BOOIJ, 2009, p. 7)
\end{abstract}

Dessa maneira, o indivíduo recorre aos diferentes significados disponíveis para ver- e escolhe aquele que melhor se enquadra ao significado pretendido, quando da produção de novas palavras. Assim, o prefixo ver- não tem valor totalmente arbitrário;

\footnotetext{
${ }^{76}$ No original: The Principle of Maximized Motivation: "If construction A is related to construction B syntatically, then the system of construction A is motivated to the degree that it is related to construction B semantically." (cf. Haiman 1985a; Lakoff 1987). (GOLDBERG, 1995, p. 67)

${ }^{77}$ No original: "The idea of a hierarchical lexicon is also in line with the consideration mentioned above that people acquire the morphological system of a language, that is, the abstract morphological schemas, on the basis of their knowledge of a set of words that instantiate these patterns. Once they have come across a sufficient number of words of a certain type, they can infer an abstract schema, and will be able to expand the relevant class of words. This means that the native speaker's competence to create new compounds and derived words is based on abstractions over sets of existing complex words and the words that are paradigmatically related to them." (BOOIJ, 2009, p. 7)
} 
se, dentre uma extensa variedade de prefixos da língua alemã, o falante decide usar especificamente o ver-, então trata-se de uma forma motivada.

\section{3 - Teoria da mesclagem - Fauconnier \& Turner (2003)}

$\mathrm{O}$ arcabouço teórico descrito até o momento, juntamente com as acepções oferecidas pelo DUDEN para o prefixo ver-, foram suficientes para explicar a maioria dos neologismos encontrados no presente estudo. A Gramática das Contruções é o principal condutor para as análises, contudo, para justificar o sentido atribuído em casos específicos, foi necessário recorrer à outra vertente da Linguística Cognitiva, a saber, a teoria da mesclagem conceptual de Fauconnier \& Turner (2003). Como lembra Ferrari (2010), “tais modelos compartilham uma visão não-modular da gramática, e suas especificidades não caracterizam necessariamente uma oposição entre eles, mas antes definem áreas complementares de investigação do fenômeno linguístico.”

Para explicar como algumas formações são construídas pelos falantes, Fauconnier \& Turner (2003) postulam a existência de espaços mentais onde determinadas características de vocábulos são fundidas, permitindo atingir o valor semântico pretendido. Em seguida, apresentamos os conceitos e como podem ser aplicados: A palavra "iate terrestre", por exemplo, faz referência a um automóvel de alto luxo e ilustra as relações envolvidas na construção do sentido. Para explicar sua origem, os autores atribuem dois espaços input para cada vocábulo da formação: input 1 - com as características relativas ao campo semântico de iate: água, capitão, curso, iate, magnata e input 2, com as marcas que fazem referências a campo terrestre: terra, motorista, carro, estrada, proprietário. A figura 1 exibe os parâmetros envolvidos no processo: 


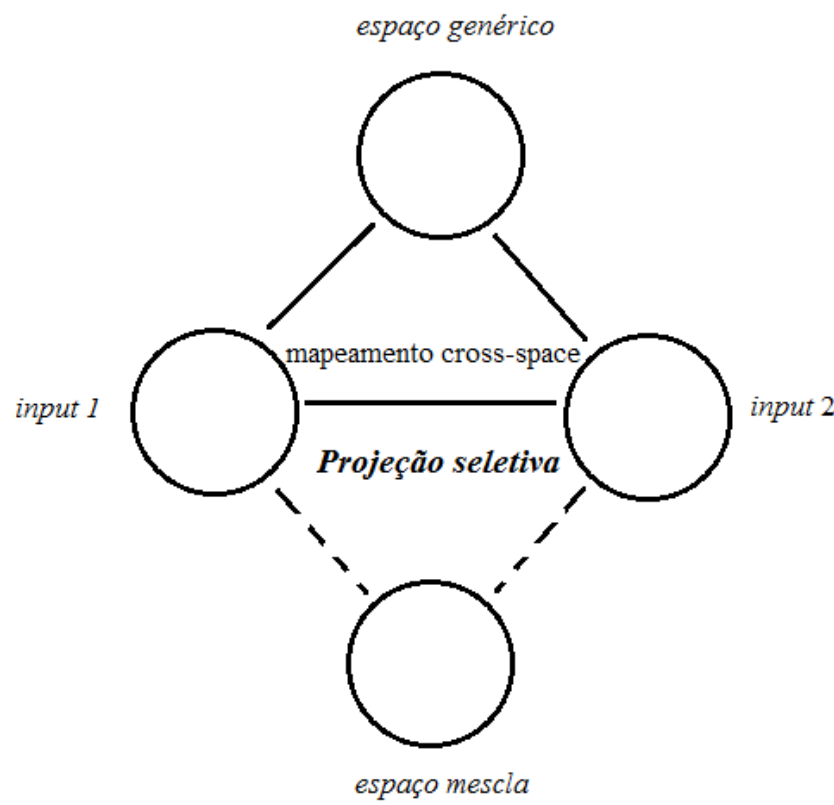

Figura 2: Mesclagem conceptual, adaptado de FAUCONNIER \& TURNER (2003, p. 3).

Na figura, o espaço genérico é o campo virtual onde os dois inputs compartilham características gerais. No caso de "iate terrestre", esse espaço seria preenchido por elementos superordenados de uma escala de categorização, tais como veículo, superfície, condutor e trajeto. Já a mescla é a situação imaginada, de onde surge a figura do iate terrestre, com suas características híbridas. Portanto, a mesclagem é o fenômeno responsável pela associação das ideias, como explica Schröder:

\begin{abstract}
“É este o fenômeno que os autores denominam 'compressões', que surge logo que topologias de espaços distintos se chocam, contribuindo para o surgimento de algo novo, pois a partir de processos de compressão e descompressão, na mesclagem, são criadas situações contrafactuais nas relações temporais, espaciais ou de identidade." (SCHRÖDER, 2010 p.133)
\end{abstract}

A compressão é um importante recurso que o ser humano utiliza em procedimentos mentais, constituindo uma prova de nossa capacidade cognitiva e criatividade. Em nosso estudo, aplicamos esse conceito para entender como são construídos os significados de novos verbos com o prefixo ver-.

Como visto no capítulo "papel da linguagem", a língua recebe influências do meio ao qual o falante está exposto. Dessa forma, a cultura, como fator inerente a 
qualquer comunidade, desempenha importante papel no pensar, refletido na fala, como lembram os autores: “as formas que encontramos em uma língua são a manifestação superficial de esquemas mesclados que emergem com a cultura e que, por sua vez, apresentam extensa aplicabilidade."78 (FAUCONNIER \& TURNER, 2003 p.21).

${ }^{78}$ No original: "The patterns we find in a language are the surface manifestation of blending schemes that have emerged within a culture and that have wide applicability." (FAUCONNIER \& TURNER, 2003 p.21) 


\section{2- METODOLOGIA}

Conforme o dicionário Langenscheidt (2010), o prefixo ver- é classificado como "inseparável, não tônico e bastante produtivo",79 na língua alemã. Entende-se por produtivo a capacidade de o prefixo formar verbetes a partir da combinação com adjetivos, advérbios ou qualquer morfema. Tomando a afirmativa como verdade e considerando o caráter polissêmico das construções com esse prefixo, procuramos neologismos da língua que pudessem revelar a formação do sentido, quando do uso do ver- pelos falantes nativos. Para tanto, buscamos verbos com o prefixo ver- em um sítio, tomado como $\operatorname{corpus}^{80}$, composto por letras de músicas de grupos alemães pertencentes ao gênero denominado hip hop. A tarefa de encontrar as entradas com o prefixo consiste na pesquisa por "ver" no campo "buscar" em cada letra de música disponível no corpus citado. Nem todos os grupos listados no sítio são de origem alemã. Assim, alguns textos estão em inglês e também na língua francesa. Para efeito de contagem, apenas os textos escritos em alemão foram considerados, totalizando 828 textos. Os resultados possíveis seriam substantivos, adjetivos e verbos. Neste estudo, detivemo-nos na análise e descrição do prefixo ver- na formação de verbos. Assim, substantivos e adjetivos foram excluídos das análises, como detalho no capítulo quatro.

A escolha do corpus deve-se a uma característica intrínseca às letras do gênero hip hop, a saber, a presença de gírias e marcas de linguagem coloquial. Devemos lembrar que o corpus deve ser adequado aos interesses do pesquisador e, nesse sentido, acreditamos que, por se tratar de textos marcados por jargões, eles poderiam contribuir para maior incidência de neologismos. Segundo Sardinha, devemos atentar para a questão da adequação, quando da escolha do corpus de pesquisa: "eu desejo investigar esta questão, então eu necessito de um corpus com estas características." (SARDINHA 2000, p. 349). Quanto à sua extensão, consideramos que os 828 textos são suficientes para o objetivo proposto. Conforme Sardinha, "os usuários de um corpus atribuem a ele a função de serem representativos de uma certa variedade." (SARDINHA, 2000 p. 345). Isso é especialmente válido para nosso estudo, uma vez que não pretendemos analisar a produtividade do prefixo ver- em si, mas descrever o processo de formação de verbos

\footnotetext{
${ }^{79}$ No original: Unbetont und nicht trennbar, sehr produktiv. (LANGENSCHEIDT, 2010)

${ }^{80}$ Disponível em http://www.deflok.de/HipHopLyrics/Texte/
} 
com as características anteriormente mencionadas, tendo como parâmetro os neologismos.

O dicionário DUDEN desempenhou dupla função neste trabalho. No primeiro momento, usamos a versão online do dicionário ${ }^{81}$ para certificarmos a não lexicalização dos verbos encontrados. Para a tarefa, utilizamos também o dicionário PONS. Caso a busca não desse resultado, o verbo seria contabilizado para fins quantitativos $\mathrm{e}$ qualitativos. Em termos quantitativos interessava-nos saber quantos verbos podem ser classificados como "novos" no corpus delimitado e em termos qualitativos, quais processos morfológicos foram usados para cada formação. Posteriormente, já nas análises, recorremos novamente ao DUDEN para conhecer as acepções que o prefixo ver- empresta às construções em que está presente. A busca por ver- no referido dicionário resulta em uma detalhada descrição dos significados do prefixo, conforme grupos de diferentes formações morfológicas.

Uma vez que os verbos analisados não estão dicionarizados, houve a preocupação em encontrar um significado para cada um e verificar em qual das acepções estabelecidas por DUDEN se encaixariam, tendo como critério também especificidades morfológicas. No exercício de interpretação dos verbos, um questionário foi elaborado e submetido a um grupo de vinte alemães de diferentes idades para verificação dos sentidos propostos. Desses, obtivemos resposta de dezessete. As sugestões de interpretação dos neologismos funcionaram como material suporte, uma vez que a análise morfológica e contextual foram os principais recursos para explicar seus significados.

\footnotetext{
${ }^{81}$ http://www.duden.de
} 


\title{
3- O PAPEL DA LINGUAGEM
}

A pesquisa sobre neologismos de verbos com o prefixo ver- no alemão envolve naturalmente o conhecimento sobre a relação do homem com a própria língua. Como visto nos capítulos anteriores, pesquisadores da linguística cognitiva ocupam-se de modelos teóricos que buscam explicar a organização de estruturas da língua na mente do ser humano. Mas outro campo de estudos, especialmente importante para entender as causas e motivações de usos de uma língua para seus usuários, é a linguagem.

\begin{abstract}
A linguagem, as línguas enquanto seus produtos, formam-se na dialética da satisfação das necessidades, ou seja, dentro do processo de instituição das relações de trabalho e de produção, também a linguagem é trabalho humano, e as línguas são a sua objetivação necessária. (ROSSI, 1985 p. 68)
\end{abstract}

Em Rossi (1985), a palavra "trabalho" é realocada para a esfera linguística e seu conceito é explicado em termos de trabalho humano, assim como a produção de artefatos materiais. Segundo o autor, a língua não é algo simplesmente natural, como a digestão e a respiração. Trata-se do produto de um trabalho maior - a linguagem. $\mathrm{O}$ homem usa a linguagem para atingir determinado fim, qual seja, comunicar entre si e alcançar seus objetivos no momento em que produz as palavras:

"As palavras e as expressões e as mensagens, enquanto coisas úteis, servem
para satisfazer necessidades expressivas, comunicativas, como exprimir,
denotar, conotar, informar, referir, qualificar, comandar, rogar, raciocinar,
conectar entre si diferentes pedaços do mesmo material linguístico." (ROSSI,
1985, p. 88)

O olhar sobre a linguagem como trabalho humano pode ser verificado em diversos campos profissionais. Além do já consagrado meio acadêmico das letras, a linguagem como "ferramenta" de trabalho é adotada também na música, cujos compositores recorrem a rimas, aliterações, entre outros recursos textuais para enriquecer suas produções. Outra característica importante a ser considerada em relação à música diz respeito à sua finalidade. A música, bem como outras manifestações culturais, não tem apenas valor artístico e cultural. É na esteira dos acontecimentos históricos que essa arte passou a ser veículo de propagação ideológica e de identidade. Assim, muitos artistas recorrem à língua, travestida de música, para engajamentos 
políticos e sociais. Em países com passado de guerras territoriais ainda é possível perceber fortes manifestações pela valorização da língua materna através da música. Tal valorização inclui muitas vezes o julgamento sobre a escolha da língua a ser cantada. A revista alemã "MKZWO" de tiragem mensal e especializada no gênero hip hop disponibiliza, também online, seu conteúdo com entrevistas com artistas do ramo, nas quais foi possível constatar a influência da língua no cenário musical. O cantor "MAXAT", de origem russo-alemã, quando questionado sobre o que pensavam seus conterrâneos russos residentes na Alemanha sobre o fato de cantar em alemão, confirma a divergência de opiniões e explica:

Uma vez que domino melhor a língua alemã, também faço rap em alemão. Muitos não queriam aceitar e odiavam. Para eles, o rap é algo que fortalece a união, tem quase uma função política. Meus motivos são outros. ${ }^{82}$ (em <<http://www.mkzwo.de/magazin/interviews/maxat>>. Acesso em $16 \mathrm{de}$ novembro de 2011)

No trecho, é importante notar que o informante faz menção ao termo rap ao invés de hip hop. Tal fato não traz problemas de aplicação teórica, uma vez que, para este trabalho, assumimos tratar-se de termos associados, em consonância com Schröder (SCHRÖDER, 2007). Conforme Verlan \& Loh (2000): “HipHop é a trindade sagrada de Rap, Breakdance e Graffiti, vociferam os puristas das primeiras vertentes do HipHop." 83 (VERLAN \& LOH, 2000 p. 13).

O hip hop apresenta características próprias, como a improvisação, a criatividade e oralidade dos textos. Segundo Verlan \& Loh (2000): “quem deseja hoje ganhar respeito na cena hip hop precisa conhecer o estilo livre. E isso significa que a pessoa precisa dominar a improvisação espontânea de rimas" 84 . Dessa forma, a escolha desse estilo musical justifica-se pelas letras marcadas pelo uso de gírias e expressões locais,

\footnotetext{
${ }^{82}$ No original: "Da ich die deutsche Sprache nun mal am besten beherrsche, rapp ich auch auf Deutsch. Das wollen viele nicht akzeptieren, und haten. Für sie ist Rap etwas, was den Zusammenhalt stärkt, schon fast eine politische Funktion einnimmt. Meine Beweggründe sind ganz andere." (em <<http://www.mkzwo.de/magazin/interviews/maxat>>. Acesso em 16 de novembro de 2011)

${ }^{83}$ No original: "HipHop ist die heilige Dreifaltigkeit von Rap, Breakdance und Graffiti, brüllen die Puristen aus allerersten Hip-Hop Reihe." (VERLAN \& LOH, 2000 p. 13).

${ }^{84}$ No original: "Wer heute in der HipHop-Szene als Rapper Respekt ernten will, der muss sich in der Disziplin Freestyle auskennen. Das heisst, er muss das spontante Improvisieren von Reimen beherrschen" (VERLAN \& LOH, 2000 p. 117).
} 
riqueza de rimas e uso de neologismos, o que provavelmente permitir-nos-á encontrar material para nossa análise, a saber, verbos ainda não dicionarizados com o prefixo ver-.

O hip hop surgiu em fins da década de setenta em Nova Iorque, nos Estados Unidos, marcado fortemente pela linguagem da população negra residente nos guetos da cidade. $\mathrm{O}$ estilo tornou-se mundialmente conhecido e apresentou variações conforme o país, principalmente quanto ao ritmo e ao tema das canções (cf. Schröder, 2009). Segundo Schröder, trata-se de um estilo musical que tem suas raízes na oralidade, baseado no ritmo e na rima: “... o novo estilo, inicialmente, desdobra-se como uma cultura da rua, na qual
batalhas (battles) de dança entre diferentes grupos de b-boys (crews),
acompanhados por música de boom box, compõem o quadro. [....] Esse canto
rítmico e rimado enraíza na tradição de duelos verbais ritualizados, como
ocorre em culturas marcadas por oralidade...” (SCHRÖDER, 2009 p. 67).

As batalhas ou duelos de rappers caracterizam as apresentações e diferem-se no conteúdo, quando as nacionalidades são comparadas. Na Alemanha, o hip hop apresenta temática de cunho autoreferencial de classe média, ou seja, discursam sobre si mesmos em relação à cena hip hop vigente (cf. SCHRÖDER, 2011, p.15). Diferentemente do estilo musical correspondente na América, o hip hop alemão não se interessava por questões de cunho econômico-social. Ademais, os textos são dotados de uma estilística que caracteriza o gênero musical:

Os campos linguísticos e estilísticos são cunhados pela informalidade, expressividade, emotividade, subpadrão, vulgarismo, gírias locais, mas também por jargões específicos. ${ }^{85}$ (SCHRÖDER, 2007, p.4)

O conceito de gênero proposto por Bazerman (2005) ajuda-nos a entender o papel das letras de músicas do referido estilo musical na pesquisa linguística proposta. Segundo Bazerman (2005), os gêneros devem ser entendidos como "fenômenos de reconhecimento psicossocial”. O termo refere-se a eventos que são reconhecidos pelas pessoas. $\mathrm{O}$ autor atenta, ainda, para o modo e finalidade quando da identificação de gêneros:

\footnotetext{
${ }^{85}$ No original: "Informalität, Expressivität, Emotivität, Substandart, Vulgärsprache, Argotelemente, aber auch fachspezifischer Jargon prägen die sprachlich-stilistische Ebene." (SCHRÖDER, 2007, p.4)
} 
(...) são fatos sociais sobre os tipos de atos de fala que as pessoas podem realizar e sobre os modos como elas os realizam. Gêneros emergem nos processos sociais em que pessoas tentam compreender umas às outras suficientemente bem para coordenar atividades e compartilhar significados com vistas a seus propósitos práticos. (BAZERMAN, 2005, p. 31).

Nesse sentido, as letras de música devem ser entendidas como formas já socialmente aceitas e detentoras de marcas pessoais propositais. Assim, quando da produção de uma faixa musical, a intenção do autor estará de alguma forma impressa na letra da música, seja para compartilhar um significado ou atender a um propósito prático senão ideológico ou cultural, conforme Bazerman (2005) salienta. Posteriormente, o ouvinte e também leitor, ao escutar a música, pode identificar-se com seu conteúdo. No Brasil, por exemplo, as letras de hip hop tem como temática a violência no país, diferenças sociais e problemas de comunidades locais. Por viverem em situações semelhantes, a identificação com o meio é reforçada.

Outro aspecto importante a ser considerado nos estudos sobre gênero é a tipificação. Todo evento apresenta características próprias que permitem às pessoas identificá-lo e categorizá-lo. Trata-se de uma padronização, de indícios, marcas e papéis individuais que nos levam a entender determinada situação como deve ser socialmente interpretada. Segundo Bazerman (2005, p. 31), os gêneros "são parte do modo como os seres humanos dão forma às atividades sociais." Tal descrição pode ser constatada não apenas no nível textual. Qualquer evento pode também ser tipificado como, por exemplo, um jogo de futebol: as pessoas reúnem-se em um espaço, o estádio, identificam o time e fazem parte de uma torcida com gritos de guerra entre outras características. Assim, há o predomínio de elementos que nos indicam como aquele evento social acontece. Para Bazerman (2005, p. 29) "tipificação" pode ser assim conceituada:

Este processo de mover-se em direção a formas de enunciados padronizados, que reconhecidamente realizam certas ações em determinadas circunstâncias, e de uma compreensão padronizada de determinadas situações, é chamado de tipificação. (BAZERMAN, 2005, p. 29)

Já Carvalho (2005, p.133), ao analisar o conceito de gênero a partir das ideias de Miller (1984), identifica o termo "recorrência", de significado correspondente ao de 
tipificação: "Esse processo de tipificação baseado em recorrência explica a natureza convencional do discurso, assim como as regularidades encontradas tanto em sua forma quanto em sua substância." Isso indica que os ouvintes esperam certo padrão em letras de músicas conforme o estilo musical. Dessa forma, é importante observar que as novas formações verbais encontradas poderiam não surgir em outros estilos musicais ou mesmo em outros gêneros, como entrevistas ou notícias de jornal.

A consciência da criação e trabalho com a língua nas letras de música é, por vezes, explícita, de forma que muitos artistas são indagados sobre o porquê dos títulos ou sobre a temática escolhida para os textos. A rapper norte-americana Kreayshawn, por exemplo, é conhecida na cena hip hop pelo uso recorrente e invenção de gírias. A cantora não explica o motivo, mas quando questionada sobre a habilidade de criar gírias, ela revela sua predileção pelo jogo com as palavras, conforme trecho de entrevista:

Então, o mais novo é $>\mathrm{BoDa}<$. $>$ Bo< é um xarope para tosse com Prometazina e codeína. Não confunfir com $>$ B.O.<, ou seja, >Body Odor $<$ [cheiro corporal, nota do editor]. BoDa é uma mistura de Bo e Soda, que em Houston chamam de $<$ Lean $>$. Mas quando digo $>\mathrm{BoDa}<$, ninguém, fora meus amigos mais íntimos, entende o que quero dizer. ${ }^{86}$ (disponível em < <http://www.juice.de /features/kreayshawn-interview <<. Acesso em 16 de novembro de 2011).

O fator consciência é um importante parâmetro a ser considerado nos estudos sobre linguagem. Rossi (1985, p. 76) identifica quatro casos particulares nos quais há esse conhecimento por parte do usuário da língua: 1- quando do ensino de língua estrangeira ou trabalho de tradução; 2- quando se ensina a criança a falar; 3- quando o objetivo é a fala e a escrita em si e finalmente; 4- em estudos científicos sobre a linguagem. Dentre todos, destaco o mais significativo para nosso trabalho: "quando falar e escrever se tornam um fim, cuja realização apresente dificuldades especiais na expressão e na comunicação." Ainda que o autor refira-se a construções poéticas, podemos aplicar esse mesmo critério para nosso estudo. É importante lembrar que

\footnotetext{
${ }^{86}$ No original: “Also, das neueste ist »BoDa«. »Bo« ist Hustensaft mit Promethazin und Codein. Nicht zu verwechseln mit »B.O.«, also »Body Odor« [Körpergeruch, Anm. d. Verf.]. (lacht) BoDa ist ein Gemisch aus Bo und Soda, das sie in Houston »Lean«nennen. Wenn ich aber »BoDa« sage, weiß in der Regel keine Sau, was ich meine - außer meine engsten Freunde." (em <<http://www.juice.de /features/kreayshawn-interview $<$. Acesso em 16 de novembro de 2011).
} 
certas letras de música são, a princípio, incompreensíveis pelo jogo de palavras e pelo uso de certos vocábulos aparentemente descontextualizados. As letras de músicas constituem um gênero no qual é esperado um formato de texto com certas marcas textuais próprias, como rimas e como visto anteriormente, especificamente no caso do hip hop, o vocabulário diferenciado, a presença de neologismos, de um tema específico, entre outros.

As possibilidades de uso de uma língua não devem ser confundidas com linguagem específica de um grupo, correndo o risco de se ter uma visão equivocada do objeto analisado. Congruente à caracterização descrita por Schröder (2007) em relação à estilística textual, defendemos a hipótese de que mesmo os grupos musicais, quando se autodenominam diferenciados pela linguagem, ao procurar uma identidade própria através dela, realizam exercício de auto-afirmação, marcando a fala com algumas gírias e expressões idiomáticas. Trata-se, essencialmente, de uma consciência metalinguística - os falantes em questão não falam uma língua diferente.

\begin{abstract}
Assim, determinadas formas textuais (carta, artigo de jornal, romances etc.) e manifestações culturais estão ligadas a tradições, não se limitam a uma única língua. Tradições discursivas são, em suas dinâmicas, parecidas com outros fenômenos de tradição cultural (música, moda, arquitetura etc.) e podem estar diretamente relacionadas a eles. ${ }^{87}$ (KABATEK, 2009, p. 173).
\end{abstract}

Uma vez fora da cena musical, do grupo com o qual se identificam e procuram reforço cultural e identitário, os indivíduos precisam adequar a linguagem ao contexto em que estão inseridos, sob o risco de não serem compreendidos.

Nas enunciações sobre a língua podemos observar, conforme identifica Schlieben-Lange (1993), dois movimentos: o saber sobre a língua e o discurso público. O primeiro deles pode ser caracterizado como a capacidade do falante em observar a própria língua e apontar novas estruturas, neologismos, expressões idiomáticas, etc. Segundo Schlieben-Lange (1993:95) "tudo isso são generalizações de experiências,

\footnotetext{
87 No original: "So sind bestimmte Textformen (Brief, Zeitungsartikel, Roman etc) und kulturelle Entwicklungen zwar durch Tradition verbunden, nicht aber auf eine Einzelsprache beschränkt. Diskurstraditionen sind in ihrer Dynamik ähnlich wie andere kulturelle traditionsphänomene (Musik, Mode, Architektur etc.) und können zu diesen in enger Beziehung stehen. ” (KABATEK, 2009, p. 173).
} 
abstrações da prática linguística que se baseiam novamente nela de maneira constitutiva.".

Já o discurso público refere-se a julgamentos a respeito da língua que são incorporados e transmitidos: "assim, o discurso público sobre língua(s) contém principalmente avaliações, isto é, julgamentos sobre 'bonito' e 'feio', 'bom' e 'ruim', etc." (SCHLIEBEN-LANGE, 1993:95). Dessa forma, o membro de uma comunidade, ao falar de sua língua passa pelos dois processos acima descritos: se por um lado ele analisa a língua e opina conforme suas experiências, por outro ele reproduz o discurso de outros através de expressões que considera ter valoração social, conforme o julgamento da sociedade quanto à forma e ao vocabulário. Tanto o saber sobre a língua quanto o discurso público podem ser observados em nosso estudo. Devido à influência da língua inglesa no mercado fonográfico, muitos músicos vêem-se confrontados com a questão linguística quando da escrita dos textos para as canções. Em entrevistas analisadas foi possível encontrar relatos sobre esse dilema, como o do grupo CharliesChoice:

\begin{abstract}
Alemão ou inglês? Devido ao meu fraco inglês deixo um pequeno repertório de vocabulário nas sessões para ajudar. Do contrário, espontaneamente não é possível nenhuma peça brilhante. ${ }^{88}$ (disponível em <http://www.mkzwo.de /category/artist/charlies-choice> Acesso em: 16 de novembro de 2011).
\end{abstract}

Ainda sobre a decisão de qual língua usar, a cantora entrevistada compara, de forma superficial, a língua alemã com a língua inglesa. Nesse processo, fica evidente o entrelaçamento do "saber sobre a língua" e do "discurso público", ao qual SchliebenLange se refere. No trecho, a artista observa a própria língua e emite julgamentos e análises acerca do valor semântico e fonológico sobre as línguas em questão:

... Minha língua materna me oferece frequentemente liberdades que me deixam confusa e tudo soa bastante polêmico. O que na língua inglesa parece corriqueiro, em alemão já parece um hit. ${ }^{89}$ (disponível em

\footnotetext{
${ }^{88}$ No original: "Deutsch oder Englisch? Aufgrund meines kleinen Englisch ist es auch hilfreich, auf Sessions ein kleines Repertoire an Vokabular zur Verfügung zu haben, da ansonsten spontan kaum geistreiche Plots möglich sind." (em <http://www.mkzwo.de/category/ artist/charlies-choice> Acesso em: 16 de novembro de 2011).

${ }^{89}$ No original: “... Meine Muttersprache bietet mir oft Freiheiten, die mich ganz durcheinanderbringen, und alles klingt schnell mal polemisch. Im englischsprachigen Bereich scheint das zwar Gang und Gäbe zu sein, im Deutschen heißt es dann aber gleich Schlager." (em <http://www.mkzwo.de/category /artist/charlies-choice> Acesso em: 16 de novembro de 2011)
} 
<http://www.mkzwo.de/category/artist/charlies-choice> Acesso em: 16 de novembro de 2011)

As entrevistas oferecem diversas contribuições para o estudo da linguagem. Nesse sentido, o grupo alemão "I-fire" configura como mais um desses casos possíveis de análise, uma vez que seus textos são escritos em língua alemã, mas ocasionalmente apresentam refrões em inglês e até mesmo em dialeto crioulo jamaicano, também denominado "Patois". Nas entrevistas coletadas, a mistura linguística não passa despercebida e o grupo é alvo de questionamentos por parte do jornalista, que o entrevista. Esse, por sua vez, também deixa escapar estereótipos a respeito do tema ao formular a pergunta: "vocês misturam alemão e inglês nos textos, isso tem a ver com o Reggae ou trata-se de um registro do nosso tempo? Fica melhor em inglês?" 90 (em $<<$ http://www.mkzwo.de/magazin/interv iews/i-fire $>>$. Acesso em 16 de novembro de 2011). A resposta dos integrantes pode ter sido influenciada pela pergunta do entrevistador, uma vez que eles não comentam a inclusão do dialeto crioulo nos textos e atêm-se à "facilidade" do inglês, apesar de escreverem em sua grande maioria em língua alemã. De qualquer forma, não deixa de ser um registro para nosso estudo, ao tratar de um exemplo de consciência metalinguística:

Escrever textos é mais fácil em inglês, provavelmente porque estamos acostumados com a mídia. Mas uma vez que não queremos servir conforto, e sim transmitir uma mensagem, [...] escrevemos de preferência na língua que melhor dominamos, ou seja - em alemão. ${ }^{91}$ (disponível em <<http://www.mkzwo.de/magazin/interviews/i-fire〉>. Acesso em $16 \mathrm{de}$ novembro de 2011).

Não menos importante para a discussão sobre a língua, é a validade dos novos vocábulos em um ambiente macro, ou seja, em lugares além da cena musical. Os exemplos encontrados podem um dia tornar-se usuais na comunidade de falantes uma vez que se encontram amparados pelo já citado poderoso veículo de comunicação, a

\footnotetext{
${ }^{90}$ No original: "Ihr mischt deutsche und englische Texte, hat das mit Reggae zu tun oder ist das allgemein Ausdruck unserer Zeit? Geht manches besser auf Englisch?” (em <<http://www.mkzwo.de/magazin/interv iews/i-fire〉>. Acesso em 16 de novembro de 2011).

${ }^{91}$ No original: "Texten ist, wahrscheinlich einfach weil man es gewohnt ist über die Medien, einfacher auf Englisch. Da wir aber nicht Gewohnheiten bedienen wollen, sondern eine Message rüberbringen, die, wie wir an der Kritik der Riddim gesehen haben, ohnehin schwer genug zu vermitteln ist, schreiben wir meistens lieber auf der Sprache, die wir am besten beherrschen -also Deutsch." (em <<http://www.mkzwo.de/magazin/interviews/i-fire〉>. Acesso em 16 de novembro de 2011).
} 
saber, a música - manifestação artística e cultural de qualquer sociedade. Ao discorrer sobre língua e comunidade, Rossi ajuda-nos a entender que a provável integração de um verbo ao vocabulário de determinada língua depende da necessidade dos falantes:

É apenas devido ao fato de responder às necessidades da comunidade inteira que a linguagem responde às necessidades do indivíduo. $\mathrm{O}$ fato de que as línguas não são criações do indivíduo, mas sim produtos da comunidade... (ROSSI, 1985 p. 69)

Independente do motivo que levou o autor a desenvolver um neologismo, o termo pode vir a ser incorporado ao vocabulário de uma comunidade. Assim aconteceu com verficken e verpissen, verbos que já estão incorporados ao cotidiano ${ }^{92}$, ainda que não se encontrem dicionarizados.

Os grupos de hip hop usam as letras de música para expressão de uma identidade própria, disseminada para um determinado público ouvinte, como explica Rossi (1985:102) acerca do uso da língua como manifestação cultural: “A linguagem é uma forma e uma expressão da sociedade, é na linguagem, ou, mais amplamente, no signo, que a sociedade se manifesta".

${ }^{92}$ Conforme www.mundmische.de (Acesso em 17 de novembro de 2011). 


\section{4- ANÁLISE DOS VERBOS}

A busca no corpus composto por letras de músicas do hip hop permitiu encontrar doze entradas com o prefixo ver-, que ainda não constam nos registros do DUDEN, a saber: verbassen, verspeien, verpeilen, verchecken, verächten, verkreuzen, verstumpfen, vergaukeln, verschlendern, vernabeln, verreimen, verstottern. O dicionário em questão não foi usado apenas como corpus de exclusão lexicográfico - como descrito anteriormente, o DUDEN oferece uma descrição detalhada do prefixo ver- com oito acepções que suas construções podem assumir. Esses grupos de significados foram as referências para a categorização das novas palavras.

$\mathrm{Na}$ condição de falantes não nativos, achamos prudente elaborar um questionário, que foi submetido a um grupo de vinte alemães de diferentes idades, para confirmar nossas interpretações acerca das palavras. Do grupo, obtivemos resposta de dezessete pessoas. A princípio, a análise contemplava dezessete palavras, mas cinco vocábulos constituíam desvios do objeto de estudo, a saber: verranzt, por ser um adjetivo, Verwöhnaromen, Verräter e Verräcken, formas substantivas, e o suposto verbo verschecht, por não ter sido reconhecido. Para esse último, alguns informantes arriscaram a forma verchecken (esquecer), mas as sugestões vinham acompanhadas de comentários imprecisos e questionamentos quanto a suas validades. No caso de Verräcken, foi atribuída a ortografia verrecken (morrer). O substantivo verwöhnaromen apresenta características de verbo na letra da música em que aparece, mas ao analisar seu contexto, notamos pertencer, de fato, à classe de substantivo. Os informantes também confirmam a classificação. Segundo os entrevistados, trata-se de uma palavra retirada de uma propaganda de café da década de 80. O significado da palavra é construído pela composição do verbo verwöhnen (mimar) e o substantivo Aroma (aroma), e foi criada no contexto publicitário para remeter ao cheiro do produto capaz de mimar o usuário, como explica o entrevistado: "Verwöhnaroma é uma invenção da propaganda alemã (acho que é usado bastante para cafés). É um substantivo combinado - verwöhnen + Aroma. Um aroma especial, que afaga os sentidos"93.

\footnotetext{
93 No original: "Verwöhnaroma ist eine Erfindung der dt Werbung (ich glaub für Kaffee wird es oft verwendet) Es ist ein zusammengesetztes Nomen $\rightarrow$ verwöhnen + Aroma. Ein besonders gutes Aroma, dass die Sinne verwöhnt. “
} 
Neste trabalho, seguimos a linha teórica adotada por Goldberg para a teoria da Gramática das Contruções e o dicionário DUDEN como parâmetro para a conferência dos grupos semânticos. A gramática DUDEN também oferece uma seção sobre morfologia, com descrições bastante correspondentes às de Donalies, a quem recorremos para esclarecer os exemplos. Admitindo-se que as construções com o prefixo ver- formem grupos de significados distintos, propomos classificações para os neologismos, de forma a relacionar cada verbo ao grupo semântico que consideramos equivalente de sentido. Ademais, sugerimos também um esquema representacional, para cada grupo identificado, com a segmentação morfológica que permite descrever o processo que dá origem a seus significados. Os verbos são analisados na sequência, conforme grupo de acepção ao qual pertencem:

\section{Grupo A}

No corpus estudado foi possível encontrar apenas um exemplo, cujas características, tanto semânticas quanto morfológicas, indicavam classificação para o primeiro grupo de acepções, conforme o dicionário DUDEN. Nesse grupo, o prefixo ver- "expressa, em formações com substantivos ou adjetivos e uma desinência, que uma pessoa ou coisa (no decorrer de um tempo) transforma-se (algo denominado pelo substantivo ou pelo adjetivo)". O verbo verstumpfen é considerado uma instanciação da construção na qual o prefixo ver- tem valor de modificação, devido ao pareamento da forma e do significado construcional, que podem ser representados pelo esquema [PREFIXO ver - + ADJETIVO + SUFIXO - en]. Ainda que stumpf seja um termo com sentido definido, são os elementos da construção que lhe conferem propriedades adicionais, apenas por ser uma instanciação do modelo representado, assumindo seus valores semânticos.

Abaixo, explicamos detalhadamente o percurso para interpretação desse único caso encontrado.

\section{a) verstumpfen}

"Ich hab die Augen weit geöffnet, immer auf der Hut wie 'n Dschungeltier, wenn du den Mut verlierst ist das herzlich dumm von dir, denn in der City musst du durch, Leute verstumpfen hier jeder geht an dir vorbei, 
undurchschaubar wie Dunkelbier." (http://www.deflok.de/HipHopLyrics

/Texte/Deichkind/Bitte_ziehen_Sie_durch_LP_2000/Smogcity.txt)

Como visto na seção "fundamentos teóricos", os verbos com o prefixo ver- são resultados de um processo de formação de palavras da língua alemã denominado derivação explícita. Conforme Donalies (2007), a base do verbo indica sua natureza, se substantiva, verbal, adverbial ou adjetiva. Assim, o sentido de verstumpfen foi esclarecido ao analisarmos sua estrutura morfológica, que permite identificar sua natureza adjetiva: [PREFIXO ver- + ADJETIVO + SUFIXO - en]. O adjetivo em questão é stumpf, cuja definição no DUDEN nos ajuda a recuperar o sentido proposto para verstumpfen: 1. Não mais cortante, não afiado. 2. Sem atividade espiritual, sem vitalidade; sem sensibilidade, indiferente e apático, quase sem vida. ${ }^{94}$ No contexto em que está inserido, o verbo verstumpfen descreve o sentimento do autor em relação à vida em uma metrópole. Sua postura alerta (immer auf der Hut) adverte o interlocutor sobre o comportamento das pessoas (denn in der City musst du durch, ... jeder geht an dir vorbei), resultado de um processo de apatia e indiferença, indicado na passagem "Leute verstumpfen hier".

Nas entrevistas, muitas respostas indicaram sinonímia com o verbo abstumpfen (tornar-se indiferente, apático, insensível) e alguns informantes propõem que, no texto, o neologismo verstumpfen tenha sido usado com o mesmo sentido. Ademais, três respostas confirmam a derivação do adjetivo stumpf, como descrito: "tornar-se indiferente, tornar apático" 95 (informante 10). Nesses casos, os entrevistados usaram o verbo werden como recurso para descrever o processo. De forma mais detalhada, o informante 2 explica a transferência de sentido de um termo usado geralmente em objetos cortantes, como facas, para o âmbito dos seres humanos, lançando mão do próprio neologismo:

"Normalmente, as pessoas vívidas tem arestas e cantos, ou seja, predileções, particularidades, traços especiais de caráter. Quando elas 'verstumpfen', os

\footnotetext{
94 No original: "1. nicht [mehr] gut schneidend; nicht scharf. 2. ohne geistige Aktivität, ohne Lebendigkeit; ohne Empfindungsfähigkeit, abgestumpft und teilnahmslos, fast leblos".

95 No original: "Abstumpfen, stumpf werden" (informante 10)
} 
cantos não existem mais, eles estão gastos, ou seja, fica tudo igual, sem motivação, sem cuidado." 96 (informante 2).

Mas afinal, como o autor chegou a esse resultado? Para explicar o fenômeno da formação de verstumpfen recorremos à teoria da mesclagem conceitual desenvolvida por Fauconnier \& Turner (2003). Conforme desenvolvido na parte teórica, podemos considerar a existência de dois inputs para a formação do sentido do termo. Um deles seria composto por características de um utensílio doméstico, como uma faca, por exemplo; ser inanimado, cortante/sem corte, deteriorável, funcional, etc. Paralelamente, teríamos os elementos que descrevem o ser humano: ser animado, provido de sentimentos, passional / racional, ser social, com defeitos, etc. No espaço genérico encontram-se as categorias superordenadas: tipo de ser, funcionalidade, características, etc. Devido ao processo chamado de "compressão", as características em comum são mescladas, resultando no novo termo. O resultado é a associação dessas características em um quarto espaço, com a consequente criação de um novo significado: um verbo usado para denominar seres humanos através de propriedades de objetos inanimados.

\begin{tabular}{|c|c|c|c|}
\hline Input 1 & Input 2 & Mescla & Espaço genérico \\
\hline Inanimado & Animado & Animado & Tipo \\
\hline Cortante & Qualidades e defeitos & $\begin{array}{c}\text { Sem corte, } \\
\text { passividade }\end{array}$ & Características \\
\hline Deteriorável & Mutável socialmente & Deteriorável & Aparência \\
& & & Funcionalidade \\
\hline Funcional & Passional /racional & Emotiva & \\
\hline
\end{tabular}

Tabela 1: mesclagem conceptual referente ao verbo verstumpfen.

\footnotetext{
96 No original: "normal sind lebendige Menschen mit Ecken und Kanten, also Vorlieben, Eigenheiten, besondere Charakterzüge. Wenn sie ,verstumpfen “, gibt es die Kanten nicht mehr, sie sind stumpf, also alle gleich, motivationslos, ohne Elan.” (informante 2)
} 
Com base nessa explanação, chegamos a uma definição mais precisa do termo, e ao mesmo tempo, conseguimos inseri-lo no primeiro grupo de acepção do DUDEN. Pelo contexto apresentado, o verbo expressa noção de desgaste temporal por fatores ambientais. A sugestão de inseri-lo no grupo A justifica-se pela carga semântica trazida pelo adjetivo stumpf, presente na raiz do neologismo.

\section{Grupo B}

O grupo B apresenta características semânticas e morfológicas sem correspondência nos verbos encontrados no corpus.

\section{Grupo C}

O terceiro grupo de acepção do prefixo ver- apresenta a seguinte estrutura morfológica: [PREFIXO ver- SUBSTANTIVO - DESINÊNCIA -en], conforme descrito pelo dicionário DUDEN. Esse grupo estabelece que o prefixo "em formações com substantivos e uma desinência, exprime que uma pessoa ou coisa é provida de outra”. Conforme a descrição foi possível identificar dois casos com esse padrão, a saber, os verbos verbassen e vernabeln. Por laços de instância, os neologismos herdaram o significado descrito acima, no qual uma pessoa ou coisa é provida de algo. A identificação dos substantivos Bass e Nabel nas formações verbais encontradas, juntamente com a interpretação sugerida pelo contexto, permitiram a alocação dos verbos no grupo C. As análises abaixo explicam o processo percorrido para decifrar o sentido dos neologismos:

\section{b) verbassen}

\footnotetext{
“Wir sind am Start und die Welt ist groß / Wir ham' kein Ziel, aber wir fahr'n los / unser Zug ist abgefahr'n doch wir sitzen drin / Niemand kann ihn stoppen, wir werden weiterrocken ... Ich verbasse die Masse, indem ich ihr neue Beats verpasse / Krieg' dafür Geld, daß ich auf'm Kiez verprasse." (http://www.deflok.de/HipHopLyrics/Texte/Absolute_Beginner/Bambule/Ro ck_On.txt acesso em 21/10/2011)
} 
Em verbassen, a tarefa de identificar a base não é tão simples, uma vez que apenas a ocultação de ver- revela o termo bassen, que não configura uma entrada lexical na língua alemã. Contudo, o contexto apresenta marcas metonímicas, como as expressões "wir werden weiterrocken" e "indem ich ihr neue Beats verpasse", de onde pudemos associar a raiz "bassen" a outro elemento do mesmo campo semântico, a saber, o instrumento musical baixo, do inglês bass. Nota-se que o empréstimo da língua inglesa ocorre também na frase anterior, junto ao verbo weiterrocken, de rock. Os informantes confirmam a natureza de "bassen". O verbo recebeu interpretações praticamente uniformes nas respostas; quase todos referiram-se ao instrumento baixo, em inglês Bass, para explicá-lo: "eu acredito que ele fez um verbo do baixo (inglês Bass). Jemanden verbassen... e depois... 'neue Beats verpasse'. Deve rimar."97 (informante 13). O informante 2 reforça a ideia de alusão ao instrumento musical: "do baixo (na música) um verbo, o que também combina com 'verpassen', no sentido de 'dar': o cantor 'dá à massa uma carga de baixo', ou seja, ele fornece a ela muita música alta." ${ }^{98}$ (informante 2). Dessa forma, assumimos que a base do verbo é o instrumento musical baixo (Bass), substantivo emprestado da língua inglesa. Assim, o neologismo verbassen é de natureza substantiva, formado pela adição do confixo verbalizador verao substantivo Bass e o sufixo -en, como desinência verbal.

Paralelamente, passamos à análise semântica do prefixo. De forma geral, Donalies atribui acepções aos prefixos, admitindo que eles possam transmitir qualidades às bases nos derivados. Para tanto, a autora cita determinadas funções que os prefixos podem apresentar. Assim, na função Instrumentiva, os prefixos, junto a certas bases, designam o instrumento utilizado na ação; por exemplo, o verbo befingern indica que o instrumento utilizado para cutucar é o dedo; o verbo beäugen atenta para os olhos como ferramenta do ato de observar e também erdolchen, que indica o punhal, como utensílio usado para atacar a vítima. No caso de verbassen, o prefixo ver- seria responsável por indicar o efeito do som produzido pelo baixo. Mas, acreditamos que tal função pode ser melhor interpretada se a entendermos como a propriedade de transformar o substantivo

\footnotetext{
${ }^{97}$ No original: "Ich schätze er macht aus dem Bass, Musik Bass [engl. bass] ein Verb. Jemanden verbassen... denn danach .... 'neue Beats verpasse'. Soll sich wohl reimen” (informante 13).

${ }^{98}$ No original: “Von Bass (in der Musik) ein Verb, was aber auch zu 'verpassen' im Sinne von 'geben' passt: der Sänger 'verpasst der Masse eine Ladung Bass', also versorgt sie mit viel lauter Musik”. (informante 2).
} 
em verbo, pois geralmente expressamos a ação pela conversão dos instrumentos [em verbos], a exemplo de esfaquear (faca), apunhalar (punhal), etc. Mas o sentido do verbo não se limitou ao significado de Bass; há um efeito provocado em um recipiente, algo possível com o instrumento musical em questão. Dessa forma, as respostas transcritas dos questionários são próximas à interpretação baseada em Donalies, e nos permitem entender o verbo "verbassen", na oração, como uma ação, cujo objetivo ou consequência seja "contagiar o público, envolver a plateia com o som produzido pelo baixo", uma vez que o instrumento do grupo é capaz de emocionar o público com seu ritmo.

Curioso foi a coincidência na interpretação de verbassen e na origem do termo "bossa nova" acerca do mesmo instrumento: "a marcação do baixo nos sambas muito impressionara os músicos locais. Claro, 'bossa' era uma corruptela de 'bass', contrabaixo em inglês.” (Luis Fernando Veríssimo, Estado de São Paulo, 13/09/2012).

Conforme visto na seção anterior, os verbos com o prefixo ver- podem ser considerados construções da língua alemã e, portanto, analisados como tais. No capítulo, sugerimos uma rede polissêmica para as construções formadas pelo prefixo, a fim de capturarmos os significados atribuídos a ele. A estrutura morfológica de verbassen é do tipo [PREFIXO ver- SUBSTANTIVO - DESINÊNCIA -en] e apresenta, portanto a mesma moldura que a dos exemplos citados na terceira acepção, do dicionário DUDEN: verschorfen e vercomputerisieren. Congruente com a descrição do grupo, o público, ao qual o autor da música se refere e, coloquialmente, denominado de "massa", é envolvido pelo instrumento musical, um substantivo, presente de forma explícita no verbo. Assim, tanto pelas características morfológicas, quanto semânticas, sugerimos a acepção de provimento ao prefixo ver- no neologismo verbassen.

A pergunta quanto à escolha do prefixo ver- e, consequentemente, como a intenção do falante corresponde ao adequado significado pretendido, ainda se mantém. Afinal, porque o compositor recorre ao prefixo ver- para criar verbassen? Uma vez que as construções com o prefixo ver-apresentam sentidos tão diversos, o prefixo é visto como elemento "curinga", que oferece variadas possibilidades. Não obstante, as possibilidades são limitadas, de forma que podemos estabelecer ligações entre as acepções demarcadas pelo DUDEN. A relação semântica entre as construções da terceira acepção, na qual incluímos o neologismo verbassen, e as do sentido central de 
"modificação" pode ser explicada por laços polissêmicos de herança, conforme Goldberg. Assim, a propriedade "provimento" é apenas uma extensão da principal característica do prefixo, a de modificar aquilo a que ele está relacionado. Tomando as acepções do dicionário DUDEN como referência, nossa hipótese é que o falante recorre ao prefixo ver- dada sua amplitude de significados. Respeitando as regras morfológicas, é possível trabalhar com as oito possibilidades de significados das construções para formar novas palavras e assim, construir o sentido pretendido.

\section{c) vernabeln}

"Schnell noch mal rüber in's Bad um uns frisch zu machen, bevor wir Kabel vernabeln mit Raps und Monitore krachen, Mikro an und nen Kopfhörer am Ohr." (http://www.deflok.de/HipHopLyrics/Texte/Plattenpapzt/Wenn\%20Zonies\%20reisen...\%20feat.\%20Tefla\%20\&\%20Jaleel.txt)

$\mathrm{Na}$ tarefa de recuperar o sentido de vernabeln, bem como de averiguar sua origem, recorremos à estrutura morfológica do neologismo, assim identificada: [PREFIXO ver- + SUBSTANTIVO + SUFIXO DESINENCIAL $-n]$. A forma indica sua natureza substantiva (der Nabel), uma vez que, isoladamente, o termo nabeln não existe. A reflexão acerca da relação entre o verbo e o substantivo que o originou parece ir além do significado primário de Nabel (umbigo), uma vez que o contexto não oferece elementos para estabelecermos relações diretas com o substantivo. Portanto, para este caso, é necessário considerar palavras que fazem parte do mesmo campo semântico de Nabel, como por exemplo, Nabelschnur (cordão umbilical) e a forma verbal abnabeln (separar o recém-nascido do cordão umbilical) ${ }^{99}$. Acreditamos que a semelhança anatômica e funcional entre o fio (cabo) e o cordão umbilical seja o motivador para o compositor da letra, na medida em que permite a associação metafórica, como ligação e fonte de alimentação. Ademais, as referências metalinguísticas, no caso, cantar e fazer música, associada à predileção por rimas, contribuem para nossa hipótese quanto ao receio do autor em produzir uma repetição do termo Kabel em verkabeln - visto que o autor poderia ter optado por esse último para produzir o mesmo sentido de vernabeln,

\footnotetext{
99 No original: (ein neugeborenes Kind) von der Nabelschnur trennen 2- sich von etwas lösen. (cf. Duden)
} 
qual seja, conectar, ligar. Nesse sentido, novamente recorremos à teoria da mesclagem (FAUCONNIER \& TURNER, 2003) para explicar o fenômeno que possibilitou a formação de vernabeln. Segundo os autores, admitimos a existência de dois campos inputs. O primeiro deles é composto por elementos associados ao substantivo Nabel (cordão umbilical): orgânico, canal de alimentação (nutrição), ligação de afeto, corpo cilíndrico. Já no segundo input podemos nomear as marcas correspondentes a Kabel (cabo): inorgânico, alimentação elétrica, ligação eletrônica, corpo cilíndrico (fio). No espaço genérico encontram-se as categorias superordenadas: natureza, funcionalidade, conexão, anatomia, etc. Como efeito da fusão de conceitos, temos no campo mescla o compartilhamento de funções dos inputs supracitados, usadas para construir o sentido de vernabeln. Segundo os autores, na mesclagem emergem traços que não podiam ser visualizados separadamente: "a mesclagem pode acomodar elementos dos espaços inputs a fornecer relações que não existem nos inputs separadamente". ${ }^{100}$ (FAUCONNIER \& TURNER, 2003 p.4). A tabela abaixo exibe o resultado:

\begin{tabular}{|l|l|l|l|}
\hline Input 1 & Input 2 & Mescla & Espaço genérico \\
\hline Orgânico & Inorgânico & Inorgânico & Natureza \\
\hline $\begin{array}{l}\text { Canal de alimentação } \\
\text { nutrição }\end{array}$ & Alimentação elétrica & $\begin{array}{l}\text { Alimentação } \\
\text { elétrica }\end{array}$ & Funcionalidade \\
\hline Ligação de afeto & Eletrônica & $\begin{array}{l}\text { Sentimental/ } \\
\text { Eletrônica }\end{array}$ & Conexão \\
\hline Corpo cilíndrico & Corpo cilíndrico (fio) & Cabo & Anatomia \\
\hline
\end{tabular}

Tabela 2: mesclagem conceptual referente ao verbo vernabeln.

Ademais, a similaridade fonética entre Kabel (cabo) e Nabel (umbigo) pode também ter influenciado na construção. O número significativo de entrevistados, que mencionam o termo Bauchnabel para entender o verbo citado, contribui para nossa

\footnotetext{
${ }^{100}$ No original: "blending can compose elements from the input spaces to provide relations that do not exist in the separate inputs" (FAUCONNIER \& TURNER, 2003, p.4).
} 
interpretação. O informante 2, incerto quanto à explicação, menciona Bauchnabel, ao mesmo tempo que brinca com os sentidos: "conectar? O umbigo uma vez esteve conectado...."

Considerando as características semânticas e morfológicas de vernabeln, sugerimos alocá-lo no grupo de acepção $\mathrm{C}$ do quadro polissêmico, no qual o prefixo ver- "em formações com substantivos e uma desinência, exprime que uma pessoa ou coisa é provida com outra”. A coisa provida em questão encontra-se oculta no texto, entretanto o resultado do verbo é evidente; o cabo conecta-se a algum instrumento ou aparelho e a música é produzida, conforme o trecho: "bater com Raps e monitores, microfone ligado e um fone de ouvido na orelha."102 Tal reflexão é congruente com um dos princípios da Linguística Cognitiva: "O indivíduo e sua interação com o meio ambiente estão no cerne da questão da interpretação do significado e da língua. O comportamento corporal e sua interação com o mundo são referências para as relações simbólicas”. (Bellavia 2007, p. 80)

\section{Grupo D}

O grupo D apresenta características semânticas e morfológicas sem correspondência nos verbos encontrados no corpus.

\section{Grupo E}

O grupo E é caracterizado por representar verbos, cuja estrutura morfológica é assim descrita: [PREFIXO ver- + VERBO]. Nesse grupo, o prefixo ver- "exprime, em formações com verbos, que uma pessoa passa o tempo com algo". De todo o material analisado, apenas dois verbos atendem a tais especificações, a saber: verspeien e veschlendern.

\footnotetext{
${ }^{101}$ No original: "verkabeln? Der Bauchnabel war ja auch mal ver "kabel" $t$...."

102 No original: "mit Raps und Monitoren krachen, Mikro an und nen Kopfhörer am Ohr."
} 
Na língua alemã, um dos recursos para descrever a dedicação a uma tarefa em determinado espaço de tempo é usar, coincidentemente, outro verbo com o prefixo ver-: verbringen. Como estratégia parafrástica, o próprio dicionário DUDEN recorre ao verbo verbringen para explicar os verbos pertencentes ao que denominamos grupo $\mathrm{E}$ no quadro polissêmico, a exemplo de verschlafen (schlafend verbringen). Como veremos, da mesma forma, usamos esse parâmetro para descrever os neologismos verspeien e veschlendern e, consequentemente, associá-los ao referido grupo. Esses verbos são considerados instanciações de uma construção da língua, cuja forma é [PREFIXO ver- + VERBO] por herdarem sua estrutura e seu valor semântico, uma vez que descrevem atividades em um processo temporal.

\section{d) verspeien}

"Das Klingen von traurigen Geigen wiederspiegelt unser Leiden, aus deepen Zeiten, über die wir Lieder schreiben, die tiefer schreiten, unsere Heat verspeien, den Krieg fighten, verwirt treiben, bis die Krisen schweigen." (http://www.deflok.de/HiphopLyrics/Texte/Azad/Mentale_Krisenfeat.Chabs. txt)

A segmentação morfológica do neologismo verspeien permite a identificação de sua natureza verbal, uma vez que sua estrutura apresenta o verbo speien (cuspir, vomitar, expelir) como a base do derivado. Como visto anteriormente, a identificação da base é de fundamental importância também para a interpretação de um neologismo. Dessa maneira, o verbo speien (cuspir) foi o motivador para o sentido sugerido. Contudo, speien, por si só, não revela todo o sentido evocado pelo neologismo e, para explicá-lo, recorremos também ao contexto em que estava presente.

A partir de elementos contextuais, entre os quais os traços metonímicos presentes na letra da música, supomos que, para os autores, escrever música seja uma atividade capaz de liberar o calor das emoções e, então, amenizar os momentos de crise, como descrito no trecho: "Das Klingen von traurigen Geigen wiederspiegelt unser Leiden, aus deepen Zeiten, über die wir Lieder schreiben, die tiefer schreiten, unsere 
Heat verspeien, den Krieg fighten, verwirt treiben, bis die Krisen schweigen." Podemos notar que o sentido do verbo não se limita ao significado de sua base; trata-se da descrição de um processo de reanimação, no qual a música é a cura para uma suposta crise mental, título da faixa. Assim, durante o processo de escrita da canção, o autor passa o tempo exteriorizando sua energia, sua emoção.

Para confirmar nossa análise, verificamos as repostas dos questionários e a maioria dos entrevistados referiram-se à base speien para atribuir um sentido ao verbo, tratando-o como um sinônimo de cuspir: "Verspeien é uma forma inventada derivada de Speien no sentido de cuspir, como em 'dragão cospe fogo'." 103 Outro informante referese à ação de expelir algo interior: "disseminar, irradiar algo através de um impulso massivo por vasta área, publicar, divulgar para as pessoas." 104

Em termos semânticos, os verbos usados pelo dicionário para ilustrar o grupo $\mathrm{E}$ possuem conotação negativa, uma vez que a pessoa perde tempo fazendo algo que não produz resultados, como por exemplo, dormir ao invés de trabalhar ou passar o tempo em uma disputa esportiva e ainda perder - daí nossa denominação de "perda, subtração" para o grupo. Mas, devemos lembrar que tal acepção descreve, também de forma neutra, a realização de qualquer atividade em determinado período de tempo, a exemplo de verschnarchen (passar o tempo roncando). Assim, acreditamos que verspeien também possa ser inscrito na acepção E, no sentido de passar o tempo dissipando sentimentos, expelindo as emoções quando da produção de uma canção.

\section{e) verschlendern}

\footnotetext{
"Problem: Fehlt nun beim schnell Sprechen die Puste und Beats mit viel Bässen hören sich mit Hörgerät an wie Sven Väth, dann ist es Zeit etwas zu ändern. Entweder den Tag zu verschlendern im Stadtpark, mit Leuten von gestern über Blader lästern oder eben dem bisschen Leben das bleibt." (http://www.deflok.de/HipHopLyrics/Texte/Opa/ Unterwegs_Zuhause_und_ daheim/Opa.txt)
}

\footnotetext{
${ }^{103}$ No original: "Verspeien ist eine erfunden Form abgeleitet von Speien im Sinne von Spucken wie z.B in „feuerspeiender Drache”. (informante 9)

${ }^{104}$ No original: "Etwas durch einen massiven Impuls großflächig und weitläufig verbreiten, ausstrahlen, verkünden, unter die Leute bringen." (informante 3)
} 
O verbo verschlendern apresenta estrutura morfológica transparente, que facilitou a identificação de sua origem verbal: [PREFIXO VER- + VERBO]. O neologismo em questão é derivado do verbo schlendern, de significado pleno na língua. Conforme o DUDEN, schlendern significa andar com movimentos naturais, vagarosamente, sem pressa. ${ }^{105}$ A princípio, essa definição, por si só, poderia satisfazer a ideia contida no trecho em que o neologismo está presente. Contudo, há um elemento na oração que provoca sutil mudança de sentido - trata-se do sintagma nominal "den Tag", capaz de delimitar o período em que ocorre a ação. Tal delimitação permitiu-nos perceber uma diferença semântica em verschlendern, atribuída ao prefixo ver-: passar determinado tempo andando lentamente, vagando. Dessa forma, o acréscimo do prefixo à base schlendern serve para salientar que uma pessoa dedica-se à tarefa de andar lentamente, sem objetivo, o que dá ênfase à atividade em questão.

Como mencionado anteriormente, o verbo verbringen também pode ser aplicado ao exemplo de verschlendern na tarefa de explicá-lo (schlendernd verbringen) e, por isso, sugerimos inseri-lo nesse mesmo grupo.

Nas entrevistas, os informantes referem-se ao sentido já construído pela base do derivado (schlendern) e, não por acaso, alguns mencionam a relação com o verbo verbringen para explicar o neologismo: “'Schlendern' significa passear, então 'den Tag verschlendern im Stadtpark' quer dizer 'passar o dia passeando no parque'. De alguma forma, o prefixo vor- (sic) exprime a ideia de que alguém gastou o dia fazendo aquilo (schlendern)."106 (informante 2). A descrição na resposta dada reforça o conceito proposto para as construções do grupo E, e corrobora nossa proposta de classificação.

\section{Grupo F}

O sexto grupo designa construções, nas quais o prefixo ver- "exprime, em formações com verbos, que uma pessoa faz algo errado, às avessas”. Dentre os verbos encontrados, foi possível identificar três com essas características: verpeilen, verächten

\footnotetext{
105 No original: a) gemächlich, mit lässigen Bewegungen gehen. b) sich schlendernd irgendwohin begeben.

${ }^{106}$ No original: “, schlendern“ heißt ,, spazieren“, also heißt „, den Tag verschlendern im stadtpark“ „,den Tag damit verbringen, im Stadtpark zu schlendern “. Die Vorsilbe vor-drückt dabei irgendwie aus, dass der Tag durch das Verb (schlendern) verbraucht wurde...” (informante 2)
} 
e verreimen. Além das propriedades semânticas, as construções do grupo seis apresentam a seguinte estrutura morfológica: [PREFIXO ver- + VERBO]. A identificação dos verbos peilen, ächten e reimen respectivamente como bases verbais, foi de fundamental importância para a classificação sugerida, juntamente com o sentido adquirido nos derivados. Assim, os novos verbos podem ser considerados instanciações de construções do grupo seis por herdarem seu significado.

\section{f) verpeilen}

"Fühl meine Nerven um Hilfe schreien, wenn Scherereien versuchen mein friedliches Dasein aufzureiben. Ich kann mich nur in begrenzte Seiten aufteilen, also seid mir nicht böse, wenn ich bisweilen mal was verpeil'." (http://www.deflok.de/ HipHopLyrics /Texte/Curse/Feuerwasser_LP_2000/Entwicklungshilfe.txt)

Apesar do atual uso coloquial ${ }^{107}$, o verbo verpeilen foi incluído para análise por ser um verbo não dicionarizado, conforme critério mencionado na seção "Metodologia". É importante notar que o verbo não foi encontrado no dicionário padrão utilizado como corpus de exclusão lexicográfico. Insistimos nessa informação, pois além da versão oficial, o DUDEN oferece ainda um dicionário de novas palavras ${ }^{108}$, onde usuários da internet inserem termos ainda não catalogados pela versão tradicional. Essa ferramenta virtual possibilitou-nos encontrar uma explicação acerca do significado de verpeilen: receber algo não organizado, não conseguir, estar improdutivo, caótico ${ }^{109}$. Outros endereços eletrônicos também oferecem definições para verpeilen, como a do sítio Mundmische:

Confuso, de lado, desligado mentalmente, desorientado, não totalmente acordado, não 'captar' algo. Estado daquele que está sobrecarregado, tem outras preocupações, ou que acorda cedo. [O termo] surgiu das viagens marítimas: Wenn man sich verpeilt, kann das böse Folgen haben nach dem

\footnotetext{
${ }^{107}$ Conforme http://www.redensarten-index.de/suche.php, entre outros. (acesso em 20/11/2012).

$108 \mathrm{http}$ ://szenesprachenwiki.de/ (acesso em 20/11/2012)

109 No original: etwas nicht organisiert bekommen, nicht hinbekommen verpeilt sein: unproduktiv sein, chaotisch sein.
} 
Motto: "Das ist Island, nicht Irland!"110 (disponível em http://mundmische.de/bedeutung/10506-verpeilt_sein, acesso em 10/12/2012)

As denotações supracitadas ajudam na tarefa de decifrar o significado do neologismo. Ainda assim, consideramos importante analisar como se deu o processo de formação e de significação de verpeilen no texto encontrado, pois neste estudo pesquisamos o papel semântico do prefixo ver-. A estrutura morfológica do verbo revela tratar-se de um derivado verbal, uma vez que conseguimos identificar a seguinte forma: [PREFIXO ver- + VERBO]. O verbo em questão é peilen, de sentido completo na língua alemã. Conforme o dicionário DUDEN, esse verbo apresenta três significados, sendo os dois primeiros e, consequentemente os prototípicos, relacionados à navegação: 1. determinar uma área ou direção para algo com uma bússola ou por meio de um dispositivo de rádio e 2. Medir a profundidade da água com uma sonda. ${ }^{111} \mathrm{O}$ terceiro sentido é ainda dividido em dois tipos, associados ao uso coloquial: direcionar o olhar para algum lugar (gíria) e entender (baixo calão) ${ }^{112}$. Ao comparar tanto as descrições oferecidas para verpeilen na internet, como as de peilen pelo DUDEN, é possível identificar certas relações semânticas, que ajudaram a investigar a origem de verpeilen.

Se considerarmos apenas os sentidos ligados à navegação, devemos lembrar o papel da metáfora para a comunicação cotidiana. Como descrito anteriormente, o verbo peilen é usado para determinar direção ou profundidade na água, ou seja, medir distâncias de um ponto a outro - na forma de uma reta. Lakoff (1990) cita a metáfora “pensamento é movimento" para lembrar casos, nos quais os locutores 'conduzem' os ouvintes por uma linha de raciocínio ao relatar uma história ou mesmo para expor seu ponto de vista. Assim, o falante refere-se ao pensamento de forma concreta, como algo em movimento em um caminho; com início, meio e fim. Portanto, consideramos que verpeilen deriva de peilen por transmitir a ideia de desvio de um traçado retilíneo, de

\footnotetext{
${ }^{110}$ No original: Wirr, neben sich, nicht ganz da, leicht desorientiert, noch nicht ganz wach, etwas nicht ganz mitbekommen. Der Zustand, wenn man überarbeitet ist, ganz andere Sorgen hat oder morgens aufsteht. Kommt aus der Seefahrt: Wenn man sich verpeilt, kann das böse Folgen haben nach dem Motto: "Das ist Island, nicht Irland!"

${ }^{111}$ No original: 1. (besonders Seewesen) mit Kompass oder mittels funktechnischer Einrichtungen Lage oder Richtung zu etwas bestimmen. 2 . (Seewesen) die Wassertiefe mit dem Peilstock feststellen.

${ }^{112}$ No original: a) (umgangssprachlich) seinen Blick irgendwohin richten b) (salopp) verstehen.
} 
uma linha reta que guia o pensamento. A causa dessa fuga é o descuido, a distração - daí atribuir ao verbo o sentido de desorientação e desorganização mental.

As respostas dos informantes seguem o mesmo raciocínio; segundo os entrevistados, o verbo é assim interpretado, pois caracteriza a pessoa que não está concentrada, foge da linha de raciocínio, está desorientada, fora do prumo (como o navio que sai da rota traçada), como detalha o informante 13: "bagunçado / esquecido / no pensamento / distraído. Quando alguém esqueceu algo ou está tão desorganizado, que simplesmente perde o fio da meada" ${ }^{\prime 13}$. Outro entrevistado também compara o significado dos verbos, e para tanto, remete à navegação: “"peilen’ significa calcular o caminho para um destino, como por exemplo, em uma viagem de navio (Peilung). 'Verpeilt' significa que alguém perdeu a orientação."114 (informante 5).

Da mesma forma, se tomarmos o uso coloquial como referência, a análise também é direcionada para a questão do pensamento. A explicação está na relação de antonímia com "entender"115, o último significado de peilen proposto pelo DUDEN. Novamente, há uma debilidade em acompanhar o raciocínio de alguém e a pessoa não compreende o conteúdo da mensagem. Para um dos informantes, o sentido de verpeilen é claro: "Não entender algo, esquecer algo"116. Aparentemente desconexa, a relação com vergessen (esquecer) é explicada por outro entrevistado: "esquecer algo... estar um pouco confuso e por isso esquecer algo..."117.

As explicações permitiram-nos alocar o verbo no grupo dos erros por ações humanas. Como descrito, o erro consiste na distração, um pequeno desvio no pensamento que leva ao não entendimento de uma explicação, por exemplo. Ainda que muitos entrevistados não explicitem a relação entre orientação, pensamento e erro na construção com o ver-, alguns arriscam a sugestão proposta neste trabalho sobre o verbo verpeilen, como conclui um dos entrevistados: "cometer um engano, enganar-se, não realizar algo como deveria ou como foi planejado. Deve vir de 'peilen', ou seja, marcar

\footnotetext{
${ }^{113}$ No original: "durcheinander / vergesslich / in Gedanken / unaufmerksam sein. Wenn jemand etwas vergessen hat oder so unorganisiert ist, dass er einfach 'nix auf die Reihe kriegt."' (informante 13)

${ }^{114}$ No original: "peilen" heißt, den Weg zum Ziel berechnen, zum Beispiel in der Schiffahrt ("Peilung"). "Verpeilt" bedeutet, dass jemand die Orientierung verloren hat."

${ }^{115}$ No Brasil, "sacar", no sentido de compreender, parece ser a tradução mais adequada para verstehen, quando usado coloquialmente por meio de gírias.

${ }_{116}$ No original: "etwas nicht verstehen, etwas vergessen." (informante 7)

117 No original: "etwas vergessen.....ein bisschen verwirrt sein und deshalb was vergessen...." (informante 11)
} 
exatamente a direção, a posição. Desviar da posição deve ser então verpeilen."118 (informante 10).

\section{g) verächten}

"Sünde verächten und gerecht unsere Brote brechen, Gebote sprechen, Leichen im Geiste aus ihrer not erwecken." (http://www.deflok.de/HipHopLyrics/Texte/ Spiritual_Warriors/Gr\%fcner\%20Tee\%20feat.\%20Curse.txt)

A princípio, pode-se pensar que o verbo verächten seja apenas um erro de digitação, pela proximidade ortográfica com o verbo verachten (desprezar). A verificação dá-se pela fonética. Ao escutar a música, fica evidente a diferença produzida pelo trema, o que nos permitiu concluir tratar-se, de fato, de um neologismo.

O próximo passo compreende a busca pelo significado do verbo e, para tanto, recorremos à análise morfológica. A estrutura morfológica identificada pode ser representada da seguinte forma: [PREFIXO VER- + VERBO]. Novamente, um caso de derivação verbal, cuja raiz é o verbo ächten (banir), de significado pleno na língua. Conforme o dicionário DUDEN, ächten pode ser interpretado como abolir (ações), expulsar, banir (pessoas). Mas qual a relação entre o prefixo ver- e um verbo com o sentido "abolir"? Como feito em outras análises, o contexto foi uma ferramenta importante para recuperar o sentido do verbo formado. Ainda que a formação de novos verbos como verächten envolva inovação de sentido, usamos o termo "formado", uma vez que outro termo como "criado", aparentemente mais adequado por explicitar a novidade, poderia levar a inadequações de ordem conceitual. Conforme Naumann (2000), Wortbildung (formação de palavras) difere-se de Wortschöpfung (criação de palavras), na medida em que o primeiro obedece a regularidades, fator determinante para nossa análise construcional.

O trecho em que se encontra o verbo apresenta temática religiosa, como indicam os vocábulos "pecados", "mandamentos" e "espíritos". Mas foi a combinação dos

\footnotetext{
${ }^{118}$ No original: "Einen Irrtum begehen, sich irren, etwas nicht so ausführen, abliefern, wie es sein sollte oder beabsichtigt war. Kommt wohl von Peilen, also etwas genau anvisieren. Daneben visieren soll dann 'verpeilen' sein." (informante 10).
} 
elementos "Sünde" (pecados) e "Brot brechen" (compartilhar o pão) que nos permitiu chegar a uma interpretação. Voltando ao texto da música, é possível notar que o tema do trecho é a redenção, o arrependimento. Consequentemente, o autor cita a justa partilha do pão como forma de ressarcimento: "Sünde verächten und gerecht unsere Brote brechen". Nesses termos, o neologismo verächten recebe conotação contrária à de sua base formadora, ou seja, salvar, redimir.

As respostas dos informantes são congruentes com nossas interpretações. Grande parte dos entrevistados atribuiu valor negativo ao verbo verächten. Para descrever sua formação, esses informantes recorreram a verbos já existentes na língua alemã e sugeriram respostas a partir de seus significados, como por exemplo, do verbo ächten (banir). Outro recurso explicitado foi associar a nova formação a uma possível fusão entre verachten e ächten, resultando um verbo de significado que remete ao erro. Curiosamente, o informante 5 lembra-nos que o verbo verächten já existiu na língua alemã, mas descarta uma relação entre a música e seu antigo uso:

\footnotetext{
“eu não sei o que exatamente quer dizer 'Sünde verächten', isso certamente vem de 'Verachtung' (desprezo) ou também de 'Ächtung' (condenação de alguém). Existe a palavra bem antiga 'verächten', mas esse Hiphopper com certeza não a conhece. Ela está no antigo dicionário dos irmãos Grimm (...)."119 (informante 5)
}

Dentre as respostas, foi possível encontrar uma que fugisse à maioria e que, contudo, avaliamos ser a mais adequada, visto que o entrevistado levou em consideração o contexto da frase: “algo como 'sühnen', ou seja, reverter os pecados (por boas ações etc.), uma vez que isso combina com 'partir nosso pão' "120 (informante 2). Essa resposta sugere que o verbo tenha valor reverso, provavelmente um processo às avessas.

\footnotetext{
${ }^{119}$ No original: “was genau mit 'Sünde verächten' gemeint ist weiß ich nicht, das kommt offenbar von 'Verachtung' (jemanden hassen) oder auch '̈̈chtung' (jemanden verurteilen, ausgrenzen). Es gibt das sehr alte Wort 'verächten', aber das kannte dieser Hiphopper bestimmt nicht. Es steht im alten GrimmWörterbuch (http://woerterbuchnetz.de/DWB/call_wbgui_py_from_form? sigle $=D W B \& m o d e=$ Volltext suche \&hitlist=\&patternlist=\&lemid=GV00306)." (informante 5).

${ }^{120}$ No original: "Etwas wie 'sühnen', also die Sünden (durch gute Taten etc.) umkehren, da dies zum 'gerecht unsere Brote brechen' passt.” (informante 2).
} 
Assim, as características de verächten são congruentes com a definição do grupo F do dicionário DUDEN, que assim o descreve: "exprime, em formações com verbos, que uma pessoa faz algo errado, às avessas".

\section{h) verreimen}

"ich reime was ich will und ich sag es aus meiner Sicht. Sicherlich? Sicherlich! Aus meiner Sicht ich gehe zurück zum Thema sonst verreime ich mich. Also Königs T ist seit langem schon dabei." (http://www.deflok.de/HipHopLyrics/Texte/State_Of_ Departmentz/Wer_sind_wir.txt)

Como visto em análises anteriores, por vezes, a identificação da base de um derivado não é tão evidente quanto parece. No caso de verreimen, duas possibilidades foram vislumbradas: o neologismo pode ter origem substantiva, visto que sua base poderia ser o substantivo "der Reim" (a rima) ou verbal, tendo por base o verbo "reimen" (rimar). A questão foi solucionada por elementos textuais: Com marcas metalinguísticas, o autor menciona o verbo reimen logo no início do parágrafo em que o verbo ocorre. A escolha pelo verbete foi proposital, na medida em que há um jogo com as palavras e seus sentidos; reimen e verreimen ocorrem no mesmo trecho para mostrar a relação antagônica existente entre eles. Enquanto reimen, uma entrada lexical de fato, indica o rimar adequadamente, seu derivado verreimen remete ao fracasso que o cantor experimentaria na tentativa de produzir rimas. Tal interpretação é reforçada pelo uso da conjunção adversativa "sonst", que marca a relação de oposição entre as orações. Assim, para este neologismo sugerimos o sentido "atrapalhar-se na rima, não produzir musicalidade ao tentar coincidir os sons das palavras".

A menção ao verbo reimen pelo autor sugere a origem verbal para o neologismo, como exibe o esquema: [PREFIXO VER- + VERBO]. Assim, os neologismos classificados para o grupo F são instâncias da construção representada e possuem suas características semânticas por herdarem o sentido "erro, às avessas" do modelo.

Com o objetivo de comparar os sentidos, buscamos nas entrevistas as sugestões de sentido para verreimen. $\mathrm{O}$ verbo recebeu interpretação quase unânime entre os 
entrevistados: rimar errado, como descreve o informante 3: "cometer um erro na rima, atrapalhar-se, embaraçar-se, enganar-se, sair do esquema de rima, perder o ritmo, bagunçar a ordem, sair do compasso (...) ${ }^{121}$. Diferentemente das descrições de outros verbos, as respostas para verreimen não foram explicadas com exaustão pela maioria dos entrevistados e indicavam obviedade de sentido para o termo. Contudo, foi possível encontrar casos isolados que, pela primeira vez, relacionam o significado de um neologismo ao de outras construções com o prefixo ver-: "rimar de forma errada, palavra inovadora, análoga a verlaufen, versalzen"122 (informante 8). Geralmente, os informantes recorrem à morfologia para explicar a origem dos neologismos e também ao contexto para sugerir sentidos, como demonstraram diversas vezes em citações anteriores. A resposta do informante 8 evidencia outro caminho de análise e é, por isso, exemplar, na medida em que explicita a analogia com outras formações com o prefixo ver-. Tal constatação é uma evidência de que o falante recorre aos grupos semânticos de construções do prefixo na formulação de novos verbos, como atesta Goldberg:

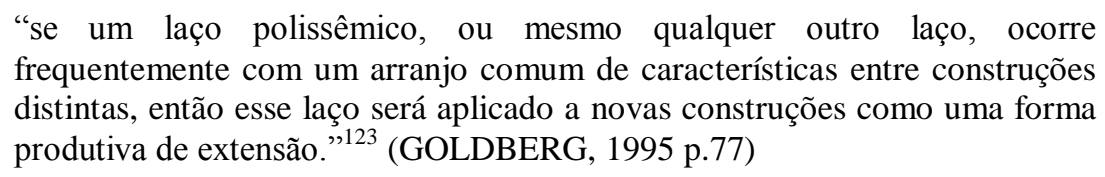

\section{Grupo G}

Seguindo os critérios adotados até então para a divisão dos grupos de acepções, o sétimo grupo apresenta verbos com a seguinte estrutura: [PREFIXO ver- + VERBO]. Além da morfologia, há de se observar o significado construcional para a classificação dos verbos. Assim, nesse grupo, estão alocados derivados, nos quais o prefixo ver“exprime, em formações com verbos, que uma coisa é prejudicada através de algo".

\footnotetext{
${ }^{121}$ No original: "Beim reimen Fehler machen, durcheinander kommen, verhaspeln, versprechen, aus dem Reimschema fallen, den Rhythmus verlieren, die Ordnung durcheinander bringen, aus dem Takt kommen, nicht zueinander passendes zusammenführen wollen." (informante 3)

${ }^{122}$ No original: "falsch reimen, innovatives Wort, analog zu verlaufen, versalzen, etc." (informante 8)

123 No original: "If a polyssemy link or any other type of link occurs frequently between distinct constructions with a shared set of characteristics, then that link will be applied to newly learned constructions as a productive form of extension." (GOLDBERG, 1995, p.77)
} 
A busca nas letras de música de hip hop possibilitou encontrar dois verbos que se enquadram nas características descritas: vergaukeln e verstottern. Por vezes, tais características não são identificáveis à primeira vista: para vergaukeln, por exemplo, não foi possível descrever sua estrutura morfológica de imediato. Assim, inicialmente buscamos o sentido do verbo oferecido pelo contexto, para então procurar o grupo de acepção, cujo sentido construcional fosse próximo. Diante da impossibilidade de saber sua origem, se substantiva ou verbal, não podíamos excluir grupos apenas pelo critério morfológico. Mas, tendo em vista que os verbos com o prefixo ver- são tomados como construções da língua alemã, assumimos que sua base é de origem verbal, pois, semanticamente, o verbo é congruente à descrição do grupo $G$ e, uma vez semanticamente motivada, ela também o é sintaticamente, para obedecer ao princípio da Motivação Maximizada (GOLDBERG, 1995 p. 67). Esse e outros procedimentos de análise são descritos a seguir:

\section{i) vergaukeln}

"Während ich der König bin, schlechthin, gib mir nur ein Microphon und ich werde das Kind schon schaukeln, ich werde dich vergaukeln, mit Schlägen so laut wie Pauken, Mann, werde ich euch Rabauken." (http://www.deflok.de/HipHopLyrics/Texte/Main Concept/Coole_Schei\%dfe_LP/Rhetorik_und_Intellekt.txt)

A estrutura do verbo vergaukeln não revela de imediato sua natureza, se verbal (gaukeln) ou substantiva (der Gaukler). Assim, esse não foi o principal recurso que utilizamos para sua classificação no grupo G. Somente a partir da análise semântica conseguimos deduzir tratar-se de uma base verbal, uma vez que seu sentido foi adequado para a descrição do grupo, composto por derivados verbais.

Dessa forma, concluímos que a base que derivou o neologismo é o verbo gaukeln, conforme o esquema sugere: [PREFIXO VER- + VERBO]. Segundo o dicionário DUDEN, o verbo gaukeln descreve um movimento desordenado, um "balançar de forma aleatória e irregular", como o voo de uma borboleta, que balança, flutuando sem destino certo. Contudo, o segundo sentido atribuído ao verbo remete a outro âmbito semântico: à habilidade de enganar ou ludibriar alguém, como em 
encenações de ilusionistas, mágicos ou acrobatas. ${ }^{124}$ Faz-se importante notar que ambos os sentidos não são inteiramente indissociáveis, bastando observar a linguagem corporal daqueles que apresentam uma peça de mágica ou de alguém que procura ludibriar outra pessoa. O sujeito em questão não fica imóvel esperando a hora de agir. Ele gesticula bastante e se movimenta repetidamente de forma irregular com o corpo, no intuito de distrair o espectador ou, no caso de um falsário, a vítima.

De qualquer forma, para entendermos se tais sentidos realmente influenciam no significado do novo verbo e, principalmente, qual deles o faz, é necessário analisar o contexto em que ele está inserido. A letra da música refere-se à rivalidade dos rappers, como comprova o trecho: "gib mir nur ein Microphon und ich werde das Kind schon schaukeln" (me dê o microfone e vou dar um jeito). Como descrito na seção "papel da linguagem", nas apresentações, há uma forma de duelo entre os músicos, que se alternam ao microfone para exibir seus talentos no jogo com as palavras, tanto em termos de conteúdo, quanto na realização de rimas improvisadas. O confronto dos cantores é uma característica do gênero musical em questão, como observa Schröder:

\begin{abstract}
"O boasting, a ostentação direta ou irônica, no rap alemão, representa um dos meios mais importantes para "eliminar" o adversário. Sendo assim, o que está no centro é uma autorrepresentação positiva de modo exagerado e, com isso, automaticamente, uma desvalorização do outro com base nos atos de fala ofensa, insulto, ostentação e autoelogio.” (SCHRÖDER, 2009 p. 70)
\end{abstract}

Na letra da música, o autor refere-se a tais confrontos de maneira metafórica, de forma a construir a sequência de rimas: schaukeln, vergaukeln, Pauken e por fim, Rabauken. Assim, supomos que em vergaukeln o prefixo ver-acrescente à base gaukeln o valor de prejuízo, uma vez que o sujeito brinca com o adversário, ludibriando-o até ver sua estratégia derrotada. Com tal interpretação, consideramos que o verbo pertença ao grupo $\mathrm{G}$ de acepções do dicionário DUDEN.

O sentido negativo atribuído ao verbo pode ser observado também nas entrevistas; a maioria dos informantes cita os verbos betrügen (enganar), verarschen (sacanear) e belügen (mentir) para explicá-lo. As respostas foram bastante congruentes e

\footnotetext{
${ }^{124}$ No original: 1- (dichterisch) leicht und spielerisch schaukelnd schweben 2 a) (gehoben) etwas vorspiegeln, vortäuschen. b) (veraltet) Zauber-, Taschenspielerkunst treiben.
} 
alguns dos entrevistados sugeriram uma origem para o verbo: "de gaukeln: encenar algo, enganar. Então, vergaukeln = ludibriar alguém, enganá-lo."125 (informante 10).

\section{j) verstottern}

"Spüre wie meine Hände zittern, während ich mir meinen Text verstotter', geb' ich Tefla noch 'nen kräftigen Schmatzer und hoff' der SPLASH!' (http://www.deflok.de/ HipHopLyrics/Texte/Tefla_und_Jaleel/Ein\%20Tag\%20am\%20See.txt)

O segundo verbo associado ao grupo $\mathrm{G}$ apresenta como base o verbo intransitivo stottern (gaguejar). Nota-se que essa é a primeira vez que mencionamos a transitividade verbal em uma análise. Nesse caso, a derivação com o prefixo ver-provocou um efeito sintático e que, por sua vez, desempenhou papel importante na tarefa de entendermos o sentido do neologismo.

Como mencionado, stottern é um verbo intransitivo e como consequência, não exige complemento. Mas, no trecho em que o seu derivado está presente, há dois complementos: um direto (meinen Text) e outro indireto (mir). O sentido de stottern é então recuperado em seu derivado e, como fator diferenciador da base, o novo verbo apresenta um objeto, que recebe os efeitos da ação do sujeito. Assim, o autor aponta o objeto, no caso o próprio texto, como prejudicado pela ação descrita na base (stottern gaguejar). Dessa forma, a necessidade de existência de um objeto é explicitar a coisa prejudicada, ou seja, o texto da música. Tal constatação permitiu-nos supor que o prefixo ver- seja o responsável por imprimir a conotação de prejuízo em algo.

Nas entrevistas, os informantes desconsideram, ou não atentam para a importância da delimitação do objeto, uma vez que apontam uma simples sinonímia com stottern, como exemplifica o entrevistado 4: "falar errado, gaguejar". ${ }^{126}$ Mas foi possível encontrar algumas respostas que mencionam o enfoque no objeto "texto", a

\footnotetext{
${ }^{125}$ No original: "Von gaukeln: Etwas vorspielen, täuschen. Also jemandem vergaukeln= jemandem etwas vorspielen, ihn täuschen" (informante 10).

${ }^{126}$ No original: "falsch sprechen, stottern.” (informante 4)
} 
exemplo da interpretação do informante 9: “'Text verstottern' no sentido de 'errar na repetição do texto' ou 'recitar o texto de forma errada ou mesmo 'esquecer' ",127.

Seguindo os princípios da gramática de construções, a noção de prejuízo atribuída aos novos derivados é herdada de outras formações verbais já cristalizadas, que são tomadas como modelos construcionais, a exemplo de verwaschen, única opção apresentada pelo DUDEN para a construção em questão. Nesse caso, a coisa prejudicada também só é revelada na sentença, na função de objeto: uma peça de roupa que sofre desgaste com o processo de lavagem e desbota: "Ich habe meine Wäsche verwaschen" (eu desbotei minha roupa).

\section{Grupo H}

O último grupo de significados proposto pelo dicionário DUDEN para o prefixo ver- apresenta uma definição pouco esclarecedora de seu papel semântico. Conforme o dicionário, o grupo compreende derivados, nos quais o prefixo ver- "em formações com verbos não tem nenhuma influência em seus significados." Tal explicação não é aprofundada e deixa margem para dúvidas, afinal, em que medida essa "não influência" pode ser observada? Acaso os derivados apresentam um significado completamente distinto do da base, ou eles simplesmente não alteram o sentido de sua raiz? Os exemplos oferecidos pelo dicionário não esclarecem a questão: de fato, o par bringen e verbringen não apresenta nenhuma relação semântica lógica, mas entre bleiben e verbleiben, a ideia de permanência é um denominador comum. Já discutimos anteriormente sobre o risco ao qual incorremos quando trabalhamos com classificações nem sempre precisas que refletem a dificuldade de sistematização da língua, dando margem a interpretações diversas, por vezes, equivocadas.

Não obstante, mesmo com esses problemas conceituais, encontramos dois verbos que apresentam as características semânticas aproximadas daquelas descritas, e morfológicas do grupo, representadas pela estrutura [PREFIXO ver- + VERBO]: verchecken e verkreuzen. Como veremos, há detalhes que fogem do rigor conceitual e, portanto, são pontos discutíveis, pois acreditamos que o grupo oito seja um espaço

\footnotetext{
${ }^{127}$ No original: “'Text verstottern' im Sinne von , sich bei der Wiedergabe des Textes vertun “ oder ,, den Text falsch wiedergeben evtl. Vergessen." (informante 9)
} 
neutro de acepção, um grupo de acesso livre de sentido, disponível aos falantes. A seguir, os casos analisados mostram essa fuga dos limites semânticos.

\section{k) verchecken}

"Sogar ihr Vater liebt meinen Style und wär gern mein Papa vercheckt seine Plattensammlung inklusive Abba trägt aufeinmal Trainingsanzüge von Kappa und sieht jetzt lieber Yo statt Tappert." (http://www.deflok.de/HipHopLyrics/Texte/DFlame/Wer\%20\%20Who.txt)

O verbo verchecken é outro caso conhecido na linguagem coloquial, mas ainda não registrado pelos dicionários formais. O dicionário de novas palavras do DUDEN oferece a seguinte definição para o verbo em questão: “quando alguém se esqueceu de algo." ${ }^{228}$. Contudo, a entrada apresenta comentários dos usuários do portal eletrônico, que também consideram "vender" um sinônimo possível, por vezes, o único. Como mencionado anteriormente, o dicionário é alimentado pelos usuários e permite contribuições quanto às definições dos verbetes. Outro endereço virtual sugere, além de “esquecer”, duas propostas de explicação: a) “... entender algo errado, fazer algo errado, mas também: comercializar drogas." b) "outra palavra para vender, usado preferencialmente em contextos com drogas". ${ }^{129}$.

Diante dessas possibilidades de significação, há de se analisar o contexto da música para conhecer o sentido pretendido pelos autores. Uma vez que a passagem em que o verbo está presente refere-se a uma coleção de discos na função de complemento verbal, presume-se que verchecken, neste caso, esteja relacionado à prática comercial. As entrevistas confirmam a interpretação: “verchecken no sentido de vender ou também

\footnotetext{
${ }^{128}$ No original: "wen [sic] man irgendwas vergessen hat." (Disponível em http://szenesprachenwiki.de /definition/vercheckt/ acesso em 15-12-2012).

129 No original: a) "etwas vergessen, etwas falsch verstehen, etwas falsch machen, auch: mit Drogen handeln" b) "Anderes Wort für verkaufen, gerne im Zusammenhang mit Drogen verwendet." (Disponível em http://mundmische.de/bedeutung/2928-verchecken, acesso em 15-12-2012)
} 
como verticken (coloquial). Verchecken e verticken são frequentemente comuns em relação ao comércio de drogas ou de produtos roubados. ${ }^{130}$ (informante 9 ).

Mas afinal, qual o motivo para tal formação? Como foi construído o sentido de verchecken? Analisando a estrutura morfológica do verbo, temos a seguinte forma: [PREFIXO ver- + VERBO]. Nesse caso de derivação, a raiz é "checken", um verbo de significado completo na língua alemã que, segundo o DUDEN, é polissêmico - no jargão técnico, o verbo pode significar "checar", "verificar", "controlar", já coloquialmente, o sentido é "entender".

Em verchecken, se considerarmos apenas o sentido "não entender", proposto por um dos dois dicionários virtuais anteriormente citados, poderíamos estabelecer relação de antonímia com checken, mesmo por que o coloquialismo é uma característica comum em ambos os casos. Contudo, o contexto não apresenta outra possibilidade de interpretação; o verbo refere-se claramente a uma transação comercial.

Uma vez que não é possível estabelecer nenhuma relação semântica entre verchecken e checken, com essa acepção, sugerimos que o neologismo seja alocado no grupo oito.

\section{l) verkreuzen}

"Für die Zukunft fragst Du Deine Karten und ich muss warten. Wenn's im Plan von Allah ist verkreuzen sich uns're Pfade." (http://www.deflok.de/HipHopLyrics/Texte/ Curse/Von_Innen_Nach_Aussen_LP_2001/Viel\%20leichter.txt)

Ao estudar a influência da estrutura morfológica no processamento cognitivo de verbos com prefixo ver-, Heide et. al. (2010) separa-os em grupos, segundo parâmetros morfológicos de suas bases. Um desses grupos é composto por verbos, cujas bases não são facilmente identificáveis, a exemplo de verlieben (apaixonar-se); afinal, verlieben deriva do substantivo feminino Liebe (amor) ou do verbo lieben (amar)? Da mesma forma, a dúvida recai para o caso de verkreuzen, pois não podemos confirmar sua

130 No original: "Verchecken im Sinne von Verkaufen oder auch im Sinne von Verticken (Umgangssprache). Verchecken und Verticken sind umgangssprachlich oftmals gebräuchlich in Bezug auf Drogenhandel oder Hehlerware." (informante 9) 
origem, se substantiva (Kreuz) ou verbal (kreuzen) Diante da impossibilidade da certeza, realizamos o caminho inverso de análise: primeiramente, deciframos o significado do verbo e somente após conferência no quadro com os sentidos construcionais, identificamos sua origem morfológica.

Para o verbo verkreuzen, parece-nos bastante evidente o sentido pretendido pelo autor e, novamente, o contexto foi o recurso usado para extraí-lo. A sequência de ações descritas indica a relação dos termos com o tema "destino": "Wenn's im Plan von Allah ist verkreuzen sich uns're Pfade." (se estiver nos planos de Alá, nossos caminhos se cruzarão.). Além da associação temática com sorte e previsão do futuro, o verbo encontra-se em uma oração com o substantivo Pfad (caminho), termo que ocorre com o verbo kreuzen. Curiosamente, o acréscimo do prefixo ver- parece não alterar o sentido da frase, o que nos permite interpretá-lo como um sinônimo de kreuzen (cruzar), no sentido metafórico de "encontrar". A pesquisa em um sítio de busca ${ }^{131}$ ofereceu resultados que mostram discreta alteração de sentido para o verbo: verkreuzen foi encontrado em textos relacionados à técnica do tricô ${ }^{132}$, em que sugerem a necessidade de cruzar o fio muitas vezes, no sentido de torcer. Isso traz ao verbo a noção de multiplicidade, mas a letra da música não sinaliza recursos para aprofundar tal interpretação.

Nas entrevistas, as respostas foram praticamente unívocas quanto ao significado de verkreuzen. A maioria dos informantes apontou relações sinonímicas com a base kreuzen. Tal percepção deve-se ao sentido já construído pelo verbo kreuzen, como lembra o informante 2: “normalmente é 'kreuzen sich Pfade', então acho que foi isso que ele queria dizer e, na música, ele precisava de uma sílaba a mais. ${ }^{133}$ Assim, alguns entrevistados procuraram explicar a existência do prefixo ver-, uma vez que sua presença é indiferente, em termos semânticos:

Booij (2009) explica que os prefixos são capazes de mudar as categorias gramaticais dos termos, como ocorre em verschlüsseln, exemplo em que o prefixo vertransforma o substantivo Schlüssel (chave) em verbo. Mas no caso de verkreuzen, nem mesmo essa propriedade foi o motivo para a escolha por ver-, pois kreuzen já é um

\footnotetext{
131 www.google.com

132 Conforme http://www.handarbeitszirkel.de/Zopfmuster.html (acesso em 20/12/2012)

${ }^{133}$ No original: "normalerweise kreuzen sich Pfade, also denke ich, dass das gemeint ist und der Rapper nur eine Silbe mehr für sein Lied gebraucht hat." (informante 2)
} 
verbo pleno capaz de converter em ação o substantivo Kreuz. Tendo em vista a ausência de efeito semântico e sintático do prefixo ver- neste caso, propomos alocar a construção verkreuzen no oitavo grupo do quadro polissêmico. Assim, aproveitamos a definição do grupo para identificar a origem do neologismo, ou seja, verbal (kreuzen).

A partir de elementos contextuais, conseguimos chegar às interpretações dos casos supracitados. Conforme discutido anteriormente, trata-se de um trabalho, cujos limites são difusos. Ainda que tenhamos seguido, desde o princípio, os parâmetros para a classificação dos novos verbos, verchecken e verkreuzen são casos que não atendem rigorosamente às descrições propostas pelo grupo de significados, o que revela a necessidade de um estudo mais aprofundado, com possível proposta de ampliação de acepções no quadro do dicionário DUDEN.

A partir da teoria da gramática de construções, o estudo realizado com os novos verbos com o prefixo ver-permitiu conhecer uma nova forma de analisar as formações que apresentam o prefixo em suas estruturas. Como visto, os verbos já cristalizados na língua funcionam como modelos fixos, com características morfológicas específicas e aspectos semânticos próprios. A busca por ver- no corpus composto por letras de músicas possibilitou identificar 12 neologismos, ou seja, palavras com o prefixo verainda não dicionarizadas, quais sejam: verbassen, verspeien, verpeilen, verchecken, verächten, verkreuzen, verstumpfen, vergaukeln, verschlendern, vernabeln, verreimen, verstottern. Esses verbos foram separados em grupos distintos, tendo como referência a definição proposta pelo dicionário DUDEN para ver-, que compreende oito acepções. Dessas, foi possível encontrar correspondência para os neologismos em cinco.

O grupo A foi contemplado com apenas um dos casos: verstumpfen. O verbo em questão foi o único a apresentar as características morfológicas e semânticas que descrevem o primeiro grupo de acepções, no qual o prefixo ver- "expressa, em formações com substantivos ou adjetivos e uma desinência, que uma pessoa ou coisa (no decorrer de um tempo) transforma-se (algo denominado pelo substantivo ou pelo adjetivo)". Após análise contextual, foi possível atribuir um significado para o neologismo verstumpfen: tornar-se apático, sem emoção.

O grupo $\mathrm{C}$ contém as propriedades que permitiram a classificação de dois neologismos: verbassen e vernabeln. No grupo, o prefixo ver- "em formações com 
substantivos e uma desinência, exprime que uma pessoa ou coisa é provida de outra". O primeiro verbo, verbassen, tem seu significado diretamente relacionado a um instrumento musical, evidenciado na base do verbo: o baixo, usado na forma inglesa "bass". Conforme o texto em que foi extraído, verbassen remete à carga de música recebida pela plateia através do instrumento em questão. Já o segundo verbo alocado no grupo, vernabeln, está associado à palavra Nabel (umbigo) e apresenta o sentido "conectar".

Em alguns verbos, recorremos à teoria da mesclagem (FAUCONNIER \& TURNER, 2003) para explicar a construção do sentido pretendido pelos autores. Este foi o caso de verstumpfen e vernabeln, cujas características indicavam a necessidade de aplicação de outros mecanismos de formação de sentidos. Como demonstrado, os conceitos de espaços mentais, compressão e mescla ajudaram-nos a desvendar a questão semântica dos verbos supracitados.

Para o grupo E foi possível encontrar também dois verbos, cujas características são equivalentes à descrição do grupo: verspeien e verschlendern. No grupo, o prefixo ver- "exprime, em formações com verbos, que uma pessoa passa o tempo com algo". Tais especificações são encontradas nos verbos, na medida em que recorremos à paráfrase para explicá-los, da mesma forma que o dicionário DUDEN o fez para descrever seus exemplos do grupo, ou seja, pelo uso do verbo verbringen. Assim, verspeien pode ser traduzido como "passar o tempo dissipando sentimentos, expelindo as emoções quando da produção de uma canção". Para tanto, foram levados em consideração o contexto e seus sentidos metafóricos, uma vez que speien remete ao ato de expelir. Igualmente, verschlendern foi assim interpretado: passar determinado tempo andando lentamente, vagando. Nota-se que esse verbo também pode ser explicado pela adição de verbringen à base do derivado: schlendern verbringen.

Dentre os neologismos, o maior número ficou reunido no grupo $\mathrm{F}$, no qual o prefixo ver- "exprime, em formações com verbos, que uma pessoa faz algo errado, às avessas". Para esse grupo, foram encontrados três casos que atendem aos requisitos semânticos e morfológicos: verpeilen, verächten e verreimen. Em todos eles é possível observar a noção contrária ou de erro relativa à base do verbo: desvio de pensamento, em sentido metafórico; redimir/ reverter os pecados e erro na tentativa de produzir rimas, respectivamente. 
O grupo $G$ descreve construções, nas quais o prefixo ver- "exprime, em formações com verbos, que uma coisa é prejudicada através de algo." No corpus, foi possível encontrar dois casos com essas características, a saber: vergaukeln e verstottern. Na tarefa de interpretá-los, recorremos ao contexto: os verbos exprimem prejuízo ao objeto nas sentenças em que estão presentes. No caso de vergaukeln, o adversário é a vítima no duelo proposto. Em verstottern, o autor recorre à metalinguagem ao apontar o próprio texto como prejudicado pela gagueira.

$\mathrm{O}$ grupo $\mathrm{H}$ revela um aspecto negativo abordado ao longo do trabalho: a limitação das classificações. Trata-se de uma tentativa de descrever a língua de forma detalhada, mas que, invariavelmente, corre o risco de não abordar certas peculiaridades. Os verbos verchecken e verkreuzen foram reservados ao último grupo, no qual o prefixo ver- "em formações com verbos não tem nenhuma influência em seus significados". A questão negativa da classificação encontra-se na aplicabilidade dessa descrição. No primeiro caso, a raiz "checken" tem significado completamente diferente do derivado prefixado, pelo menos no contexto em que foi encontrado. Já em verkreuzen, a base não sofre alteração semântica com a presença do prefixo. Assim, a ausência de efeito semântico na construção pode ser observada em ambos os casos, mas de forma distinta, e esse critério foi determinante para alocá-los no grupo, além da observância de suas estruturas morfológicas, caracterizadas pela existência de raiz verbal.

A análise dos verbos com o prefixo ver- sob a ótica da Gramática das Construções possibilitou compreender o fenômeno da derivação de forma não arbitrária. Trata-se de produtos de um mecanismo composto de conceitos e regras, que buscam descrever associações cognitivas do falante, a exemplo do modelo de herança proposto por Goldberg (1995), na tentativa de mostrar como as construções adquirem os significados de outras já existentes. O arcabouço teórico utilizado mostrou-se de fundamental importância para aprofundar os estudos dos derivados com o prefixo ver-, na medida em que serviu de ferramenta para esclarecer questões de ordem tanto semântica, quanto morfológica. Nesse sentido, acreditamos que essa maneira de analisar os derivados com o prefixo ver- possa contribuir para o ensino de alemão como língua estrangeira, uma vez que as relações descritas ao longo do trabalho permitem criar estratégias de aprendizagem vinculadas à sistematização dos casos envolvidos. 
Ademais, esperamos que a presente pesquisa possa contribuir para outros estudos relacionados à gramática de construção, em especial, àqueles voltados ao ensino de língua estrangeira, de forma a expandir os métodos de aprendizado, não apenas de vocabulário, como também no âmbito da morfologia, com ênfase na formação de palavras da língua alemã. 


\section{5- CONSIDERAÇÕES FINAIS}

O presente trabalho teve como proposta investigar o uso do prefixo ver- na língua alemã atualmente. Para tanto, usamos um sítio eletrônico, tomado como corpus, composto por letras de músicas do gênero hip hop. A análise desenvolvida na pesquisa consistia em capturar o significado que o prefixo ver- imprimia em formações verbais ainda não dicionarizadas para verificar as variações semânticas do referido prefixo. O caráter polissêmico do prefixo ver- foi observado no dicionário DUDEN online, versão que ofereceu 8 diferentes acepções para o ver-, conforme a estrutura morfológica descrita em cada uma. $\mathrm{O}$ dicionário funcionou também como ferramenta de exclusão lexicográfica, além do dicionário PONS: as possíveis entradas foram verificadas nos dois materiais para certificarmos que se tratava de novas formações não lexicalizadas.

No estudo, foi necessário desconstruir uma ideia errônea do senso comum: isolado, o prefixo ver- não tem significado algum, uma vez que é definido como afixo, unidade morfológica sem conteúdo semântico. Portanto, o estudo tratou do significado que as palavras, ou mesmo morfemas, assumiam quando da junção ao prefixo ver-. Como visto ao longo do trabalho, tal junção é, na realidade, um processo morfológico de formação de palavras na língua alemã, denominado derivação. Assim, os verbos encontrados são morfemas ou palavras que sofreram derivação, e consequentemente, obedeceram a regras e normas definidas.

Posteriormente, a regularidade das características semânticas e morfológicas dos derivados permitiu a aplicação da teoria da Gramática das Construções aos neologismos encontrados. A teoria lança luz na questão do significado dos verbos com prefixo verao identificar a existência de modelos construcionais que funcionam como referência para o falante na produção de novas palavras. Trata-se de formações linguísticas com estruturas morfológicas definidas e sentidos específicos, que servem de modelos virtuais para formações semelhantes da língua. Conforme defendido pela teoria, os novos derivados seriam instanciações desses modelos abstratos na medida em que repetem suas estruturas morfológicas e suas características semânticas. Como visto, tal relação pode ser representada em uma estrutura lexical hierarquizada. Ademais, a teoria procura mostrar que o caminho para identificar o sentido dos verbos não está nas partes 
constituintes isoladamente, mas nas construções, ou seja, nas próprias formações verbais.

A orientação para os significados dos verbos baseou-se nas acepções oferecidas pelo dicionário DUDEN online. Contudo, o trabalho com categorizações parece ser incompleto, visto que há a possibilidade de algum caso não ser contemplado pela regra. A proposta de FISCHER, K. \& STEFANOWITSCH, A. (2006) cita a propriedade distributiva para o prefixo ver-, contudo, tal acepção não é verificada nos casos previstos pelo DUDEN, apesar de ser uma característica plausível.

Este estudo, até onde conseguimos avançar, comprova a dificuldade de sugerir e sistematizar os mecanismos que levam o falante a usar o prefixo ver-. Não obstante, a gramática de construção possibilita analisar os verbos formados com o prefixo de forma satisfatória, na medida em que postula a existência de modelos construcionais, cujas estruturas e significados são fixos, podendo servir de orientação ao usuário da língua na produção de neologismos com o prefixo ver-. 
BAZERMAN, C. Gêneros textuais, tipificação e interação. São Paulo: Cortez, 2005

BELLAVIA, Elena. Erfahrung, Imagination und Sprache. Die Bedeutung der Metaphern der Alltagssprache für das Fremdsprachenlernen am Beispiel der deutschen Präpositionen. Tübingen: Günter Narr Verlag, p. 80- 97, 2007

BOAS, Hans C. Annual Review of Cognitive Linguistics 6. John Benjamins Publishing Company, p.113-144, 2008.

BOOIJ, G. Compounding and construction morphology. In: Lieber, R. \& Stekauer, P. (Eds.), The Oxford Handbook of Compounding. Oxford: Oxford University Press, p. 201-216, 2009.

BOOIJ, G; LEHMANN, C; MUGDAN, J. Morphologie: ein internationales Hanbuch zur Flexion und Wortbildung / herausgegeben von Geert Booij, Christian Lehmann, Joachim Mugdan. Berlin: New York, de Gruyter, 2000.

CARVALHO, G. Gênero como ação social em Miller e Bazerman: o conceito, uma sugestão metodológica e um exemplo de aplicação. In: MEURER, J.L.; BONINI, Adair; MOTTA-ROTH, Désirée (orgs) Gêneros: teorias, métodos, debates. São Paulo: Parábola. 2005.

CASTILHO, A. Nova Gramática do Português Brasileiro. São Paulo: Editora Contexto, 2010.

CORPUS. Disponível em http://www.deflok.de/HipHopLyrics/Texte/. Acesso em inúmeras vezes ao longo do trabalho, sendo difícil estipular uma data.

CROFT, W. \& CRUSE, D. Cognitive Linguistics. An Overview of Construction Grammars. Cambridge: University Press, 2004.

DICIONÁRIO DUDEN. Disponível em http://www.duden.de. Acesso em inúmeras vezes ao longo do trabalho, sendo difícil estipular uma data.

DONALIES, E. Basiswissen Deutsche Wortbildung. Tübingen: Francke, 2007.

EISENBERG, P. Das Wort. Grundriss der deutschen Grammatik. J.B. Metzler, 2006.

REVISTA. http://www.juice.de/features. Acesso em 16 de novembro de 2012.

REVISTA HIP HOP. DISPONÍVEL http://www.mkzwo.de/magazin. Acesso em 16 de novembro de 2011.

FAUCONNIER, G. \& TURNER, M. Conceptual blending, form and meaning. Recherches en communication, $\mathrm{n}^{\circ}$ 19, 2003.

FERRARI, L. Modelos de gramática em linguística cognitiva: princípios convergentes e perspectivas complementares. In: Cadernos de Letras da UFF Dossiê: Letras e cognição n. 41, p. 149-165, 2010. 
FISCHER, K.; STEFANOWITSCH, A. Konstruktionsgrammatik: Ein Überblick. In Kerstin Fischer and Anatol Stefanowitsch (eds), Konstruktionsgrammatik. Von der Anwendung zur Theorie (Stauffenburg Linguistik 40). Tübingen: Stauffenburg, p.3-17, 2006.

FLEISCHER, Wolfgang. Grundzüge der Wortbildung des Verbs in der deutschen Sprache der Gegenwart. Leipzig, 1967.

GOLDBERG, A. Constructions: A Construction Approach to Argument Structure. The University of Chicago Press, 1995

HALL, Karin; SCHEINER, Barbara. Übungsgrammatik für Fortgeschrittene. Deutsch als Fremdsprache. München: Hueber Verlag, 2011

HEIDE, J; LORENZ, A; MEINUNGER, A; BURCHERT, F. The influence of morphological structure on the processing of German prefixed verbs. In: Cognitive Perspectives in Word Formation. Edited by Alexander Onysko, Sascha Michel. Göttingen: De Gruyter, 2006.

KABATEK, Johannes; PUSCH, Claus D. Spanische Sprachwissenschaft. Textlinguistik, Diskurstraditionen, gesprochene und geschriebene Sprache. Tübingen: Narr Francke Attempto Verlag, p. 165-182, 2009.

KLUGE, F. Etymologisches Wörterbuch der deutschen Sprache. Bearb. von Elmar Seebold 24., durchges. und erw. Aufl. - Berlin; New York: de Gruyter, 2002.

LAKOFF, Georg. Women, Fire, and Dangerous Things. What categories reveal about the Mind. Chicago: University of Chicago Press, p. 77-114, 416-461, 1987.

The Syntax of Metaphoric Semantic Roles. In Semantics and the Lexicon, James Pustejovsky (Ed.), Studies in Linguistics and Philosophy, Kluwer Academic Publishers. Dordrecht, 1990.

LANGENSCHEIDT Großwörterbuch Deutsch als Fremdsprache. München: Langenscheidt Verlag, 2010.

LEOPOLD, Max. Die Vorsilbe ver- und ihre Geschichte. Germanistische Abhandlungen 27. New York: Georg Olms Verlag Hildesheim, p. 3-50, 1907

LEWANDOWISKI, T. Linguistiches Wörterbuch. 5. Überarbeitete Auflage. Heidelberg, Wiesbaden: Quelle u. Meyer, 1990.

LINGUAGEM COLOQUIAL. Disponível em http://mundmische.de/bedeutung. Acesso em 10 de dezembro de 2012.

LINGUAGEM COLOQUIAL DUDEN. http://szenesprachenwiki.de/. Acesso em 20/11/2012)

LINKE, A; NUSSBAUMER, M \& PORTMANN, P. Studienbuch Linguistik. Ergänzt um ein Kapitel von Urs Willi 'Phonetik und Phonologie'. 3., unveränderte Auflage. Tübingen: Niemeyer, 1996 
MORPHOLOGIE. http://hypermedia.ids-mannheim.de/call/public/bib.ansicht. Acesso em 03/01/12.

NAUMANN, Bernd. Einführung in die Wortbildungslehre des Deutschen. 3., neubearbeitete Auflage. Tübingen: Max Niemeyer Verlag, 2000.

NÜBLING, D. Historische Sprachwissenschaft des Deutschen. Eine Einführung in die Prinzipien des Sprachwandels. Tübingen: Narr Francke Attempto Verlag, 2006.

PESQUISA. Disponível em www.google.com - Acesso em 15/10/2012.

PINTO JUNIOR, João Moraes. O morfema prefixal ver- da língua alemã. Dissertação de mestrado apresentada ao Departamento de Letras modernas da Faculdade de Filosofia, Letras e Ciências Humanas da Universidade de São Paulo. São Paulo, 1987.

PONS Großwörterbuch Deutsch als Fremdsprache. Stuttgart: Ernst Klett Sprachen $\mathrm{GmbH}, 2006$.

PÖRINGS, Ralf \& Schmitz, Ulrich. Sprache und Sprachwissenschaft. Eine Kognitiv orientierte Einführung. Tübingen: Gunter Narr Verlag, p. 27-52, 1999.

ROSSI-LANDI, F. A linguagem como trabalho e como mercadoria: uma teoria da produção e alienação linguísticas. São Paulo: Difel, 1985.

SARDINHA, T. Linguística de Corpus. Histórico e Problemática. D.E.L.T.A. Vol $16, \mathrm{n}^{\mathrm{o}} 2$, p.323-367, 2000.

SCHERFER, P. Handbuch Fremdsprachenunterricht. Hrsg. Karl-Richard Bausch, Herbert Christ, Hans-Jürgen Krumm. 4. Auflage. Francke, 1995.

SCHIRMEIER, M. German ver-Verbs. Internal Word Structure and Lexical Processing. Berkeley Insights in Linguistics and Semiotics, General Editor, vol. 63. Peterlang, 2006.

SCHLIEBEN-LANGE, B. História do falar e história da linguística. Editora Unicamp, 1993.

SCHRÖDER, Ulrike. Tendenzen gegenläufiger Reterritorialisierungen in brasilianischen und deutschen Rap-Texten. Lusorama, no. 71-72, Novembro (2007): 217-243, 2007.

Revista Observatório Itaú Cultural / OIC - n. 8 (abr./jul. 2009). - São Paulo, SP: Itaú Cultural, 2009.

A mesclagem metafórica de fauconnier \& turner e as teorias de karl bühler e wilhelm stählin: antecipações e complementos. In: Revista da ABRALIN, v.9, n.1, p. 129-154, jan./jun. 2010

A Culture-specific construction of meaning utilising the LIFE IS WAR metaphor in Brazilian and German rap lyrics. In: Finger, Anke; Kathöfer, Gabi; Larkosh, Chris. (Org.). KulturConfusão. Berlin, New York: Walter de Gruyter, 2011. 
VERCOMPUTERISIEREN. http://www.agrar.de/pferde/forum/index.php?topic=27513. 215;imode. Acesso em 15 de novembro de 2011.

VERISSIMO, L. O grande silêncio. O estado de São Paulo, São Paulo, 13 de setembro de 2012. Disponível em http://www.estadao.com.br/noticias/impresso,o-grandesilencio-,929924,0.htm\}. Acesso em 13/09/2012

VERLAN, Sascha; LOH, Hannes. 20 Jahre Hiphop in Deutschland. Höfen: Hannibal Verlag GmbH, 2000.

WARTEND VERBRINGEN. Disponível em http://www.efge.at/zeitfresser-facebook Acesso em 20 de outubro de 2012 


\section{Anexos}

\section{Anexo I - Umfrage}

Unten steht eine Liste mit 17 Verben, die noch nicht in Wörterbüchern zu finden sind. Es geht um Wörter, die aus HipHop Texten stammen. Schreiben Sie bitte kurz, was Sie unter den Verben verstehen. Sie finden unter jedem Verb den Kontext, in dem es vorgekommen ist und der Ihnen bei der Deutung helfen kann. Sie können auch mehr Informationen über die Texte auf den angegebenen Webseiten erfahren, falls der genannte Kontext nicht aufschlussreich genug ist. Achten Sie darauf, dass einige Wörter schlicht Rechtschreibfehler sein können!

\section{1- verbassen}

„Wir sind am Start und die Welt ist groß / Wir ham' kein Ziel, aber wir fahr'n los / unser Zug ist abgefahr'n doch wir sitzen drin / Niemand kann ihn stoppen, wir werden weiterrocken ... Ich verbasse die Masse, indem ich ihr neue Beats verpasse / Krieg' dafür Geld, daß ich auf'm Kiez verprasse."

http://www.deflok.de/HipHopLyrics/Texte/Absolute_Beginner/Bambule/Rock_On.txt

\section{2- verspeien}

„Das Klingen von traurigen Geigen wiederspiegelt unser Leiden, aus deepen Zeiten, über die wir Lieder schreiben, die tiefer schreiten, unsere Heat verspeien, den Krieg fighten, verwirrt treiben, bis die Krisen schweigen."

http://www.deflok.de/HipHopLyrics/Texte/Azad/Mentale Krisen feat._Chabs.txt

\section{3- verpeilen}

„Fühl meine Nerven um Hilfe schreien, wenn Scherereien versuchen mein friedliches Dasein aufzureiben. Ich kann mich nur in begrenzte Seiten aufteilen, also seid mir nicht böse, wenn ich bisweilen mal was verpeil'.“ 


\section{4- verchecken}

a) „Sogar ihr Vater liebt meinen Style und wär gern mein Papa vercheckt seine Plattensammlung inklusive Abba trägt aufeinmal Trainingsanzüge von Kappa und sieht jetzt lieber Yo statt Tappert.“ http://www.deflok.de/HipHopLyrics/Texte/D-Flame/Wer\%20\%20Who.txt

b) „Thema gegessen, ich muß gehen und jemand treffen, dessen Neffen verchecken, danach geh ich mit Deiner Freundin essen.“ http://www.deflok.de/HipHopLyrics/Texte/Curse/Feuerwasser_LP 2000/Ladykiller\%2 0feat.\%20Aylah.txt

\section{5- verächten}

„Sünde verächten und gerecht unsere Brote brechen,Gebote sprechen, Leichen im Geiste aus ihrer not erwecken.“

http://www.deflok.de/HipHopLyrics/Texte/Spiritual_Warriors/Gr\%fcner\%20Tee\%20feat.\%20C $\underline{\text { urse.txt }}$

\section{6- verkreuzen}

„Für die Zukunft fragst Du Deine Karten und ich muss warten. Wenn's im Plan von Allah ist verkreuzen sich uns're Pfade.“

http://www.deflok.de/HipHopLyrics/Texte/Curse/Von_Innen_Nach_Aussen_LP_2001/Viel\%20 leichter.txt

\section{7- Verstumpfen}

„Ich hab die Augen weit geöffnet, immer auf der Hut wie 'n Dschungeltier,wenn du den Mut verlierst ist das herzlich dumm von dir, denn in der City musst du durch, Leute verstumpfen hier jeder geht an dir vorbei, undurchschaubar wie Dunkelbier.“ 
http://www.deflok.de/HipHopLyrics/Texte/Deichkind/Bitte_ziehen_Sie_durch_LP_2000/Smog city.txt

\section{8- Veräter}

„Meine oberste plicht represent meine Familie denn ohne gehts nicht und seit dem ich Mikrofone ergriff über Scenes wo ich wohne bericht brauch nur Homiez um mich all die Hater und veräter macht ein bogen um mich ihr seit verlogen wie nichts sorg für wirbel in deinem Viertel alter ich scheiss auf so ein Geschiss.“

http://www.deflok.de/HipHopLyrics/Texte/D-

Flame/Wo\%20sind\%20wir\%20daheim\%20\%20feat.\%20Tone,\%20Chabs, \%20Real\%20J.txt

\section{9- Vergaukeln}

„Während ich der König bin, schlechthin, gib mir nur ein Microphon und ich werde das Kind schon schaukeln, ich werde dich vergaukeln, mit Schlägen so laut wie Pauken, Mann, werde ich euch Rabauken.“

http://www.deflok.de/HipHopLyrics/Texte/Main_Concept/Coole Schei\%dfe LP/Rhetorik und Intellekt.txt

\section{0- Verschecht}

„oder namensgedächtnis/ seid sicher, daß ich mich nicht erinner, suave verschecht es/ seit einiger zeit mach ich hier den selben test/ wer hält mich fest, weil mir wohl nicht mehr zu helfen ist.“

http://www.deflok.de/HipHopLyrics/Texte/Nico_Suave/Vergesslich.txt

\section{1- verschlendern}

„Problem: Fehlt nun beim schnell Sprechen die Puste und Beats mit viel Bässen hören sich mit Hörgerät an wie Sven Väth, dann ist es Zeit etwas zu ändern. Entweder den Tag zu verschlendern im Stadtpark, mit Leuten von gestern über Blader lästern oder eben dem bisschen Leben das bleibt.“ http://www.deflok.de/HipHopLyrics/Texte/Opa/Unterwegs_Zuhause_und_daheim/Opa.txt 


\section{2- vernabeln}

„Schnell noch mal rüber in’s Bad um uns frisch zu machen, bevor wir Kabel vernabeln mit Raps und Monitore krachen, Mikro an und nen Kopfhörer am Ohr.“ http://www.deflok.de/HipHopLyrics/Texte/Plattenpapzt/Wenn\%20Zonies\%20reisen...\%20feat. \%20Tefla\%20\&\%20Jaleel.txt

\section{3- verreimen}

„ich reime was ich will und ich sag es aus meiner Sicht. Sicherlich? Sicherlich! Aus meiner Sicht ich gehe zurück zum Thema sonst verreime ich mich. Also Königs T ist seit langem schon dabei.“

http://www.deflok.de/HipHopLyrics/Texte/State Of Departmentz/Wer_sind wir.txt

\section{4- verstotter}

„Spüre wie meine Hände zittern, während ich mir meinen Text verstotter', geb` ich Tefla noch 'nen kräftigen Schmatzer und hoff' der SPLASH!" http://www.deflok.de/HipHopLyrics/Texte/Tefla und Jaleel/Ein\%20Tag\%20am\%20See.txt

\section{5- Verräcken (Subst)}

„Wir komm`aus Minden , die stätte des Verräckens deiner Streckenposten Jungs die strotzen lass` ich parieren auf Lattenrosten“" http://www.deflok.de/HipHopLyrics/Texte/Der_Klan/Ultimate Chiefrockers.txt

\section{6- verwöhnaromen}

„ich schmachte nach futtern wie bei muttern und nach schöner wohnen nachm kaffeeklatsch und nach ihren verwöhnaromen. sie soll ruhig wissen, dass egal wieviel props ich hättete.“ 
http://www.deflok.de/HipHopLyrics/Texte/Eins_Zwo/Gefaehrliches_Halbwissen_LP_1999/Die _Omi_aus_dem_ersten_Stock.txt

17- verranzt

„Und bist am nächsten Morgen neben dem Teufel erwacht? Ich stand am Rand deines Bettes und war ziemlich verranzt, doch ich hatte längst meinen Samen in dein Hirn gepflanzt.“

http://www.deflok.de/HipHopLyrics/Texte/Thomas_D/Uns\%20trennt\%20das\%20Leben.txt 
1- Unten steht eine Liste mit 17 Verben, die noch nicht in Wörterbüchern zu finden sind. Es geht um Wörter, die aus HipHop Texten stammen. Schreiben Sie bitte kurz, was Sie unter den Verben verstehen. Sie finden unter jedem Verb den Kontext, in dem es vorgekommen ist und der Ihnen bei der Deutung helfen kann. Sie können auch mehr Informationen über die Texte auf den angegebenen Webseiten erfahren, falls der genannte Kontext nicht aufschlussreich genug ist. Achten Sie darauf, dass einige Wörter schlicht Rechtschreibfehler sein können!

das Publikum mit tiefen Bässen erfreuen

zerstören

etwas nicht begreifen

verkaufen

verurteilen

treffen

unsensibler werden

unloyale Personen

betrügen

vergessen

faulenzen

einstecken

sich versprechen

falsch rezitieren

Sterben

entspannende Düfte

dreckig

2- Unten steht eine Liste mit 17 Verben, die noch nicht in Wörterbüchern zu finden sind. Es geht um Wörter, die aus HipHop Texten stammen. Schreiben Sie bitte kurz, was Sie unter den Verben verstehen. Sie finden unter jedem Verb den Kontext, in dem es vorgekommen ist und der Ihnen bei der Deutung helfen kann. Sie können auch mehr Informationen über die Texte auf den angegebenen Webseiten erfahren, falls der genannte Kontext nicht aufschlussreich genug ist. Achten Sie darauf, dass einige Wörter schlicht Rechtschreibfehler sein können!

1- Antwort: Von Bass (in der Musik) ein Verb, was aber auch zu „verpassen“ im Sinne von ,geben“ passt: der Sänger „verpasst der Masse eine Ladung Bass“, also versorgt sie mit viel lauter Musik.

2- ?????

3- Antwort: etwas (Termin/Sache etc) vergessen

4- Antwort: bei a) würde ich sagen, dass es vielleicht „verticken“ heißt, also umgangssprachlich für „verkaufen“. Ansonsten heißt es so etwas wie „loswerden“ würde ich sagen; bei b) allerdings hätte ich eher „abchecken“ wie „mustern, abschätzen" gedacht, ansonsten kann es alles Mögliche bedeuten!

5- Antwort: Etwas wie „sühnen“, also die Sünden (durch gute Taten etc.) umkehren, da dies zum „gerecht unsere Brote brechen“" passt.

6- Antwort: normalerweise kreuzen sich Pfade, also denke ich, dass das gemeint ist und der Rapper nur eine Silbe mehr für sein Lied gebraucht hat. 
7- Antwort: normal sind lebendige Menschen mit Ecken und Kanten, also Vorlieben, Eigenheiten, besondere Charakterzüge. Wenn sie „,verstumpfen“, gibt es die Kanten nicht mehr, sie sind stumpf, also alle gleich, motivationslos, ohne Elan.

8- Antwort: Verräter!!!!! Ganz normales deutsches Wort, geht sicher bis ins Mittelalter zurück!!! Und sogar Word hat das Wort als deutsches Wort erkannt und nicht rot unterschlängelt!

9- Antwort: das geht wahrscheinlich auf den Gaukler im Mittelalter zurück, der die Edelleute bei Hofe unterhalten hat. Vergaukeln heißt dann wohl jemanden betrügen (vom netten Wort „VERarschen“ abgeleitet)

10- Antwort: die Internetquelle zeigt mir, dass die Lyrics selbst von jemanden aufgeschrieben worden, der die deutsche Rechtschreibung nicht beherrscht. Daher denke ich, dass das eigentlich ,vercheckt" heißen soll (weil ja auch das Lied ,Vergesslich“ heißt), was „vergessen“ bedeutet.

11- Antwort: „schlendern“ heißt „spazieren“, also heißt „,den Tag verschlendern im stadtpark“ „den Tag damit verbringen, im Stadtpark zu schlendern“. Die Vorsilbe vordrückt dabei irgendwie aus, dass der Tag durch das Verb (schlendern) verbraucht wurde...

12- Antwort: verkabeln? Der Bauchnabel war ja auch mal ver"kabel"t....

13- Antwort: analog zu ,versprechen“" = falsch reimen.

14- Antwort: nicht „vorstottern“??? das würde mehr Sinn machen, nämlich das jemand nicht vorträgt, sondern vorstottert, also beim Vortragen stottert. Mit ver- weiß ich leider nicht.

15- Antwort: Meiner Meinung nach heißt „,verrecken“ sterben, also „das Verrecken“ der Tod.

16- Antwort: auch dies ist ein ganz normales Wort (Substantiv): Verwöhn + Aromen, es lebe die deutsche Morphologie. Also Aromen, die verwöhnen.

17- Antwort: Schmutzig, unausgeschlafen.

3- Unten steht eine Liste mit 17 Verben, die noch nicht in Wörterbüchern zu finden sind. Es geht um Wörter, die aus HipHop Texten stammen. Schreiben Sie bitte kurz, was Sie unter den Verben verstehen. Sie finden unter jedem Verb den Kontext, in dem es vorgekommen ist und der Ihnen bei der Deutung helfen kann. Sie können auch mehr Informationen über die Texte auf den angegebenen Webseiten erfahren, falls der genannte Kontext nicht aufschlussreich genug ist. Achten Sie darauf, dass einige Wörter schlicht Rechtschreibfehler sein können!

verbassen

Jemanden mit lauter Musik, besonders mit tiefen Bässen und schnellem Rhythmus, beschallen oder zum tanzen anregen.

Verspeien

Etwas durch einen massiven Impuls großflächig und weitläufig verbreiten, ausstrahlen, verkünden, unter die Leute bringen.

verpeilt

Etwas nicht verstehen, vergessen, durcheinander bringen. Jemandem oder etwas aus Zeitnot, Überforderung, Unkonzentriertheit oder Unwissen nicht folgen können, nicht zu Stande bringen, nicht schaffen oder nur fehlerhaft ausführen.

verchecken

zu a) Etwas verkaufen, ,an den Mann bringen“, über eBay versteigern. 
zu b) ? Vielleicht jemanden kurz treffen um etwas abzusprechen, etwas auszumachen oder etwas zu übergeben. [Ich bin mir nicht sicher.]

verächten

Vermutlich eine Kombination aus ,verachten“ und „verächtlich“. Etwas ablehnen, als nicht gut ansehen, nicht unterstützen.

verkreuzen

Vermutlich aus „sich kreuzen“ (Wege/Pfade), also sich überschneiden, verbinden, Kontakt haben, aufeinander treffen.

Verstumpfen

Gleichgültig werden, abstumpfen, gefühlskalt und teilnahmslos werden. Verkommen, sich gehen lassen, desinteressiert und unempfindlich werden. Verwahrlosen!

Veräter

Vermutlich „Verräter“, also ein nicht vertrauenswürdiger Mensch. Ein Betrüger, der andere Menschen hintergeht, um für sich einen Vorteil zu gewinnen.

vergaukeln

Jemandem etwas vorspielen, jemanden unterhalten, jemanden mit etwas beeindrucken.

Verchecht

? Keine Ahnung. Vielleicht von „verchecken, verpeilen“, also etwas vergessen, nicht schaffen, nicht zustande bringen, nicht hinkriegen.

verschlendern

Die Zeit mit unwichtigen Dingen verbringen, die Zeit verschwenden. Ziellos umher bummeln, durch die Gegend laufen, spazieren gehen ohne Ziel.

vernabeln

Etwas zusammenführen, verbinden, einstecken oder anschließen (Kabel), ankoppeln.

verreimen

Beim reimen Fehler machen, durcheinander kommen, verhaspeln, versprechen, aus dem Reimschema fallen, den Rhythmus verlieren, die Ordnung durcheinander bringen, aus dem Takt kommen, nicht zueinander passendes zusammenführen wollen.

verstottern

Ins Stottern geraten, den Redefluss unterbrechen, stocken, stammeln, sich nicht richtig artikulieren können, versprechen.

Verräcken (Subst)

Vermutlich von "verrecken", also umkommen, sterben, abkratzen, ins Gras beißen etc. Aber auch verwahrlosen, dahinvegetieren, verkümmern, siechen, darben, verrohen, unter unwürdigen Bedingungen leben, hausen.

verwöhnaromen

Angenehmer Duft oder Geschmack, besonders in Bezug auf Kaffee. Ausdruck eines bestimmten Gefühls/Zustand: sich wohlfühlen, sich an etwas laben können, genießen, erfreuen, ergötzen, in etwas schwelgen, naschen, schlemmen, sich etwas hingeben, etwas empfangen. Vermittelt Wärme, Zärtlichkeit, Geborgenheit, Erfüllung, Befriedigung, Glück, Genuss.

verranzt

Körperlicher Zustand: ungepflegt sein, ungewaschen sein, stinken, dreckige Klamotten tragen, einen Kater haben (Alkohol/Drogen), träge, unbeweglich, schwach und langsam sein.

Geistiger Zustand: verschlafen sein, unaufmerksam, schwerfällig, unfähig klar zu denken, benebelt, betäubt, berauscht, langsam und schwach, tranig, träge. 
4- Unten steht eine Liste mit 17 Verben, die noch nicht in Wörterbüchern zu finden sind. Es geht um Wörter, die aus HipHop Texten stammen. Schreiben Sie bitte kurz, was Sie unter den Verben verstehen. Sie finden unter jedem Verb den Kontext, in dem es vorgekommen ist und der Ihnen bei der Deutung helfen kann. Sie können auch mehr Informationen über die Texte auf den angegebenen Webseiten erfahren, falls der genannte Kontext nicht aufschlussreich genug ist. Achten Sie darauf, dass einige Wörter schlicht Rechtschreibfehler sein können! verbassen jemanden niedermachen, klein machen, elimnieren verspeien verbreiten, bekannt machen

verpeilt

nicht auf der Höhe, nicht konzentriert, abgelenkt

verchecken

verkaufen

verächten

bestrafen

verkreuzen

werden sich treffen, werden sich kreuzen

Verstumpfen

werden desinteressiert, stumpfen $a b$

Veräter

ein Substantiv in dem Fall mit Minuskel

vergaukeln

verarschen, belügen

Verchecht

???

verschlendern

mit Nichtstun verbringen, verplempern

vernabeln

verbinden, reinstecken

verreimen

einen falschen Reim machen

verstotter

falsch sprechen, stottern

Verräcken (Subst)

Stätte des Sterbens, des Ende der Welt,

verwöhnaromen

aus der Werbung (Kaffee? Anspielung)

verranzt

fertig, mir ging's nicht gut, Kater

5- Unten steht eine Liste mit 17 Verben, die noch nicht in Wörterbüchern zu finden sind. Es geht um Wörter, die aus HipHop Texten stammen. Schreiben Sie bitte kurz, was Sie unter den Verben verstehen. Sie finden unter jedem Verb den Kontext, in dem es vorgekommen ist und der Ihnen bei der Deutung helfen kann. Sie können auch mehr Informationen über die Texte auf den angegebenen Webseiten erfahren, falls der genannte Kontext nicht aufschlussreich genug ist. Achten Sie darauf, dass einige Wörter schlicht Rechtschreibfehler sein können! 
verbassen (von "Bass"):

Soll wohl heißen: "mit Bass-Tönen volldröhnen", vermutlich angelehnt an "jemandem etwas verpassen", zum beispiel "ich verpasse jemanden eine ohrfeige". Also eine heftige, unerwünschte Aktion.

verspeien (von "speien"):

Speien heißt zum Beispiel spucken, sich erbrechen. Bei Goethe heißt es in einem Gedicht: "Die geborstene Erde scheint Flammen zu speien". "Unsere Heat verspeien" soll wohl soviel heißen wie "Unsere Energie, unser Feuer rauslassen und anderen dabei schaden"

verpeil (von "peilen"):

"peilen" heißt, den Weg zum Ziel berechnen, zum Beispiel in der Schifffahrt ("Peilung"). "Verpeilt" bedeutet, dass jemand die Orientierung verloren hat. "Wenn ich bisweilen mal was verpeil" heißt: wenn ich mal was nicht mitbekomme, falsch einschätze"

verchecken:

keine Ahnung was das bedeuten soll :-/

verächten:

Was genau mit "Sünde verächten" gemeint ist weiß ich nicht, das kommt offenbar von "Verachtung" (jemanden hassen) oder auch "Ächtung" (jemanden verurteilen, ausgrenzen). Es gibt das sehr alte Wort "verächten", aber das kannte dieser Hiphopper bestimmt nicht. Es steht im alten Grimm-Wörterbuch

(http://woerterbuchnetz.de/DWB/call_wbgui_py_from_form?sigle=DWB\&mode=Volltextsuch e\&hitlist=\&patternlist=\&lemid=GV00306).

verkreuzen:

"Unsere Wege/ Pfade kreuzen sich" bedeutet, wir sehen uns wieder. "Ver"-kreuzen macht hier eigentlich keinen Sinn. Vielleicht meint er: unsere (Lebens)Wege

"verharken", "verkeilen" sich, bleiben irgendwie schicksalhaft miteinander verbunden

verstumpfen:

Das scheint ein Wortspiel aus "versumpfen" (versacken, unkontrolliert versinken, z.B. wegen Alkohol) und "abstumpfen" (wegen der blassen Eintönigkeit des Umfeldes verblöden) zu sein.

veräter: Das ist falsch geschrieben, gemeint ist "Der Verräter"

vergaukeln:

Gaukler nannte man früher Clowns, Akrobaten, Unterhaltungskünstler, es kann aber auch "Betrüger" bedeuten. "Vergaukeln" ist vermutlich ein Wortspiel aus "vorgaukeln" (vortäuschen) und "verschaukeln" (reinlegen, betrügen).

verschecht:

keine Ahnung :-(

verschlendern 
Schlendern bedeutet ziellos herumgehen, "verschlendern" heißt, den Tag "mit Herumschlendern verbringen"

vernabeln:

keine Ahnung :-(

offenbar abgeleitet von (Bauch-)Nabel, macht aber keinen Sinn

verreimen (von "Reim"):

Wortspiel im Sinne von "falsch reimen", wie "ich habe mich verlaufen" im Sinne von "ich bin falsch gelaufen", vom Weg abgekommen

verstottern (von "stottern"):

"den Text verstottern" meint: Durch das Stottern kann er den Text nicht richtig

rüberbringen, blamiert sich

verräcken:

Das ist wohl ein Schreibfehler, gemeint ist "verrecken" (jämmerlich krepieren")

verwöhnaromen:

Das ist ein Substantiv aus der Kaffee-Werbung: Der Kaffee hat ein Aroma, das einen verwöhnt, daher "Verwöhnaroma"

verranzt:

Das kommt von "ranzig" und wird nur adjektivisch verwendet, z.B. "der verranzte Raum" im Sinne von "verdreckt"

6- Unten steht eine Liste mit 17 Verben, die noch nicht in Wörterbüchern zu finden sind. Es geht um Wörter, die aus HipHop Texten stammen. Schreiben Sie bitte kurz, was Sie unter den Verben verstehen. Sie finden unter jedem Verb den Kontext, in dem es vorgekommen ist und der Ihnen bei der Deutung helfen kann. Sie können auch mehr Informationen über die Texte auf den angegebenen Webseiten erfahren, falls der genannte Kontext nicht aufschlussreich genug ist. Achten Sie darauf, dass einige Wörter schlicht Rechtschreibfehler sein können!

Verbassen $=$ einen Ton tiefer - Bass hinzufügen - verdunkeln

Verspeien $=$ auskotzen $=$ im Schwall erbrechen

Verpeilt $=$ verwirrt, irritiert

Verchecken $=$ verkaufen

Verächten $=$ hassen $=$ in jedem Fall vermeiden

Verkreuzen $=($ an einer Kreuzung $)$ begegnen, aus engl. Xing, crossing

Verstumpfen = verblöden, in lähmende Gewöhnung fallen

Veräter = Spalter, arbeitet ,dagegen“"

Vergaukeln $=$ anlügen, verarschen

Verschechen $=$ vergessen, verlegen,

verschlendern $=$ faulenzen, nicht sinnvoll beschäftigen

vernabeln $=($ an einen zentralen Punkt $)$ verlegen

verreimen $=$ off topic kommen in einem Text, der sich reimt (Gedicht, Lied)

Verwöhnaromen = Kaffeeduft

Verranzt $=$ verschwitzt stinken, Körpergeruch haben, eine Dusche brauchen 
7- Unten steht eine Liste mit 17 Verben, die noch nicht in Wörterbüchern zu finden sind. Es geht um Wörter, die aus HipHop Texten stammen. Schreiben Sie bitte kurz, was Sie unter den Verben verstehen. Sie finden unter jedem Verb den Kontext, in dem es vorgekommen ist und der Ihnen bei der Deutung helfen kann. Sie können auch mehr Informationen über die Texte auf den angegebenen Webseiten erfahren, falls der genannte Kontext nicht aufschlussreich genug ist. Achten Sie darauf, dass einige Wörter schlicht Rechtschreibfehler sein können!

verbassen

etwas mit tiefen Frequenzen unterlegen, rocken, wegfegen

verspeien

??

verpeilt

etwas nicht verstehen, etwas vergessen

verchecken

etwas verkaufen

verächten

etwas verabscheuen

verkreuzen

etwas, das sich ineinander verschlingt, hier: religiöse Bedeutung

Verstumpfen

auch: abstumpfen, ein Abschwächen der Sinneswahrnehmung

Veräter

Nomen, von: Verräter

vergaukeln

jemanden zum Narren halten

Verchecht

??

verschlendern

Zeit vergeuden durch zielloses Umherziehen

vernabeln

etwas verbinden

verreimen

das Reimschema nicht beachten, sich versprechen

verstotter

etwas unter starker Beeinträchtigung (evtl. Alkohol) schreiben

Verräcken (Subst)

sterben

verwöhnaromen

Nomen, Wort aus der Werbung: gut duften

verranzt

übermüdet und ungeduscht sein

8- Unten steht eine Liste mit 17 Verben, die noch nicht in Wörterbüchern zu finden sind. Es geht um Wörter, die aus HipHop Texten stammen. Schreiben Sie bitte kurz, was Sie unter den Verben verstehen. Sie finden unter jedem Verb den Kontext, in dem es vorgekommen ist und der Ihnen bei der Deutung helfen kann. Sie können auch mehr Informationen über die Texte auf den angegebenen 
Webseiten erfahren, falls der genannte Kontext nicht aufschlussreich genug ist. Achten Sie darauf, dass einige Wörter schlicht Rechtschreibfehler sein können!

verbassen

mit Bass beschallen, oder Musik für sie mit viel Bass spielen

verspeien

verbreiten???

verpeilt

etwas vergessen oder falsch machen

verchecken

a) verkaufen

b) keine Ahnung, ehrlich gesagt ;-)

5- verächten

Mischung aus verachten und ächten, wie dissaprove

6- verkreuzen

wahrscheinlich: kreuzen, treffen,

7- Verstumpfen

wie abstumpfen, jeder macht sein eigenes Ding ohne Empathie für die anderen haben

8 - Veräter

Verräter

9 - vergaukeln

???

10 - Verchecht

???

11- verschlendern

vertrödeln, die Zeit nicht effektiv verbringen (wahrscheinlich positiv konnotiert)

12- vernabeln

_verlinken. Wortspiel mit Bauchnabel

13- verreimen

falsch reimen, innovatives Wort, analog zu verlaufen, versalzen, etc

14- verstotter

den Text wegen Stottern falsch sprechen

15- Verräcken (Subst Kaputtgehen, Sterben)

16- verwöhnaromen

Anspielung auf eine Kaffeewerbung, das Aroma des Kaffees verwöhnt die Konsumenten

17- verranzt

wahrscheinlich schmutzig, zu wenig Schlaf...

9- Unten steht eine Liste mit 17 Verben, die noch nicht in Wörterbüchern zu finden sind. Es geht um Wörter, die aus HipHop Texten stammen. Schreiben Sie bitte kurz, was Sie unter den Verben verstehen. Sie finden unter jedem Verb den Kontext, in dem es vorgekommen ist und der Ihnen bei der Deutung helfen kann. Sie können auch mehr Informationen über die Texte auf den angegebenen Webseiten erfahren, falls der genannte Kontext nicht aufschlussreich genug ist. Achten Sie darauf, dass einige Wörter schlicht Rechtschreibfehler sein können!

verbassen 
Verbassen ist eine erfundene Verbform, abgeleitet von Bass im Sinne von ,jemanden mit Bass oder Bässen zudröhnen“".

Verspeien

Verspeien ist eine erfunden Form abgeleitet von Speien im Sinne von Spucken wie z.B in ,feuerspeiender Drache“.

verpeilt

Verpeilen ist umgangssprachlich in Sinne von Vergessen (manchmal auch „sich vertun").

verchecken

a) Verchecken im Sinne von Verkaufen oder auch im Sinne von Verticken (Umgangssprache). Verchecken und Verticken sind umgangssprachlich oftmals gebräuchlich in Bezug auf Drogenhandel oder Hehlerware.

b) Im Zitat b) wird das Wort verchecken sinnenfremdet oder auch sinnlos verwendet. Was damit gemeint ist, ist unklar bzw. nur der Autor des Zitats weiß, was er damit gemeint hat.

verächten

Der Autor meint sicherlich „,verachten“ oder „ächten“ benutzt aber „verächten“ aufgrund der Reimform. Im Sinne von „Kostverächter“. Allerdings ist das Verb „verachten“" und nicht „,verächten“. Das Verb, das es gibt, ist „ächten“, was aber nicht „verächten“" ist.

verkreuzen

Aufgrund mangelnder Deutschkenntnisse benutzt der Autor „verkreuzen“ antelle von „kreuzen“ (Wege kreuzen sich). Wie zuvor schon bei „fragst du deine Karten“, womit er sicherlich Karten befragen oder Karten deuten beim Kartenlesen z.B. einer Wahrsagerin meint.

Verstumpfen

Der Autor meint sicherlich, dass man ,abgestumpft“ sein muss oder dass man durch da Stadtleben abgestumpft wird, oder aber im Stadtleben abgestumpft sein sein muss. Verstumpfen also im Sinne von „Leute stumpfen ab" oder „L Leute sind abgestumpft".

Veräter

Der Autor meint „Verräter“. Es handelt sich also lediglich um einen Rechtschreibfehler. vergaukeln

Es gibt das Verb „gaukeln“ oder „,vorgaukeln“ (der Gaukler). Hier wird (warum auch immer) das Wort „vergaukeln“ (welches es nicht gibt) im Sinne von ,verprügeln“ verwendet.

Verchecht

Das ist sicherlich ein Schreibfehler. Der Autor meint sicherlich „,verchecken“ als falsche Form von „,checken“ im Sinne von verstehen oder sich erinnern.

verschlendern

Den Tag zu verschlendern im Sinne von den Tag zu vertrödeln durch schlendern (langsames Spazieren) im Stadtpark.

vernabeln

Vernabeln im Sinne von verbinden oder vernetzen oder anschließen. Abgeleitet von Nabelschnur.

verreimen

Verreimen im Sinne von „sich in Reimen verrennen „, oder sich ,in oder beim Reimen verlieren".

verstotter 
„Text verstottern“ im Sinne von „sich bei der Wiedergabe des Textes vertun“ oder „, den Text falsch wiedergeben evtl. vergessen.

Verräcken (Subst)

Schreibfehler. Der Autor meint Verrecken (qualvoll oder langsam sterben).

verwöhnaromen

Mehrzahl von „Verwöhnaroma“. Begriff aus einer Werbung für Kaffee (Jacobs Kaffe mit dem Verwöhnaroma).

verranzt

Verranzt im Sinne von geschafft, kaputt, verschlafen oder verkatert

10- Unten steht eine Liste mit 17 Verben, die noch nicht in Wörterbüchern zu finden sind. Es geht um Wörter, die aus HipHop Texten stammen. Schreiben Sie bitte kurz, was Sie unter den Verben verstehen. Sie finden unter jedem Verb den Kontext, in dem es vorgekommen ist und der Ihnen bei der Deutung helfen kann. Sie können auch mehr Informationen über die Texte auf den angegebenen Webseiten erfahren, falls der genannte Kontext nicht aufschlussreich genug ist. Achten Sie darauf, dass einige Wörter schlicht Rechtschreibfehler sein können! verbassen

Verbassen: Mit Bass beschallen, das Publikum mit dem Instrument Bass beharken. verspeien

Verspeien: Publizieren, Verbreiten, Ausspucken, Ausspeien verpeilt

Verpeilen: Einen Irrtum begehen, sich irren, etwas nicht so ausführen, abliefern, wie es sein sollte oder beabsichtigt war. Kommt wohl von Peilen, also etwas genau anvisieren. Daneben visieren soll dann ,verpeilen“ sein. verchecken

Checken: Prüfen, Auskundschaften, begreifen, verstehen. Verchecken: Bei b) evt. gleiche Bedeutung.

verächten

Verächten: Verachten?! Evt. ein Wortwitz mit Bezug auf die türkischen Umlaute oder Unterscheidung und korrekter Gebrauch von achten/ächten ist dem Poeten nicht klar. verkreuzen

Verkreuzen: kreuzen, evt. ist gemeint mehrfach keuzen_

Verstumpfen

Verstumpfen: Abstumpfen, stumpf werden.

Veräter

Verräter:

vergaukeln

Vergaukeln: Von gaukeln: Etwas vorspielen, täuschen. Also jemandem vergaukeln= jemandem etwas vorspielen, ihn täuschen.

Verchecht

Verschecht: ???? Schreibfehler? _

verschlendern

Verschlendern: Zeit totschlagen durch spazieren gehen

vernabeln

Kabel vernabeln: Kabel miteinander verbinden unter Nutzung von Steckkontakten. verreimen

Verreimen: Falsch reimen.

verstotter 
Verstotter: Stotternd sprechen.

Verräcken (Subst)

Verräcken: Schreibfehler: Verrecken.

verwöhnaromen

Verwöhnaromen: Anspielung an eine Werbung von Tschibokaffe aus den 80igern.:

Kaffe mit „Verwöhnaroma“.

Verranzt

Verranzt: Von ranzig. Also hier übertragen: Nicht gut gehen, nicht in optimaler Form sein.

11- Unten steht eine Liste mit 17 Verben, die noch nicht in Wörterbüchern zu finden sind. Es geht um Wörter, die aus HipHop Texten stammen. Schreiben Sie bitte kurz, was Sie unter den Verben verstehen. Sie finden unter jedem Verb den Kontext, in dem es vorgekommen ist und der Ihnen bei der Deutung helfen kann. Sie können auch mehr Informationen über die Texte auf den angegebenen Webseiten erfahren, falls der genannte Kontext nicht aufschlussreich genug ist. Achten Sie darauf, dass einige Wörter schlicht Rechtschreibfehler sein können!

verbassen

den Bass über die Masse legen.

verspeien

verdrängen_

verpeilt

etwas vergessen.....ein bisschen verwirrt sein und deshalb was vergessen....

$-\rightarrow$ in diesem Sinn kann man auch verchecken oder verraffen verwenden_ verchecken

etwas verkaufen $\rightarrow$ sonst kann man verchecken auch für verpeilen verwenden....

verächten

bestrafen $\rightarrow$ ächten gilt als eigenständiges Wort, deshalb weiß ich nicht, ob es für deine Arbeit wirklich relevant ist (http://de.wiktionary.org/wiki/\%C3\%A4chten)

verkreuzen

kreuzen $\rightarrow$ unsere Wege kreuzen sich (Dt Redewendung)

Verstumpfen

betäuben, abstumpfen....in diesem Fall verlieren die Leute ihre Sensibilität und gehen blind durchs Leben

Veräter

Verräter $\rightarrow$ Traidor ...auch hier solltest du noch mal gucken, ob es für deine Arbeit wichtig ist $\rightarrow$ Das Wort sollte im Duden zu finden sein + ist ein Nomen

vergaukeln

Verarschen, verkacken, sich über jemanden Lustig machen

Verchecht

ich denke hier handelt es sich wieder um vercheckt

(http://www.magistrix.de/lyrics/Nico\%20Suave/Vergesslich-22070.html)

in diesem Fall meint vercheckt, also wie oben erwähnt: vergessen, verraffen.

verschlendern

den Tag vergeuden. Den ganzen Tag im Park schlendern, ohne etwas produktives zu tun vernabeln

in Anlehnung an die Kabel verkabeln $\rightarrow$ würde sich aber doof anhören, deshalb vernabeln. Die Kabel richtig installieren 
verreimen

falsch reimen

verstotter

stottern....den Text kaputt machen, indem man stottert.

Verräcken (Subst)

erbärmliches, unwürdiges Sterben

verwöhnaromen

hier musst du auch nochmal schauen....Verwöhnaroma ist eine Erfindung der dt Werbung (ich glaub für Kaffee wird es oft verwendet) Es ist ein zusammengesetztes Nomen $\rightarrow$ verwöhnen + Aroma. Ein besonders gutes Aroma, dass die Sinne verwöhnt. verranzt

unordentlich, schäbig, vergammelt. Nicht zurecht gemacht.

12- Unten steht eine Liste mit 17 Verben, die noch nicht in Wörterbüchern zu finden sind. Es geht um Wörter, die aus HipHop Texten stammen. Schreiben Sie bitte kurz, was Sie unter den Verben verstehen. Sie finden unter jedem Verb den Kontext, in dem es vorgekommen ist und der Ihnen bei der Deutung helfen kann. Sie können auch mehr Informationen über die Texte auf den angegebenen Webseiten erfahren, falls der genannte Kontext nicht aufschlussreich genug ist. Achten Sie darauf, dass einige Wörter schlicht Rechtschreibfehler sein können!

1- verbassen

Mit einem Bass versehen.

2- verspeien

etwas herausspucken

3- verpeilt

etwas durcheinander bringen

4- verchecken

a) Verkaufen

b) ?jdm Drogen verkaufen?

5- verächten

verachten, missbilligen

6- verkreuzen

durcheinander kommen, in Konflikt geraten

7- Verstumpfen

abstumpfen, unsensibel und teilnahmslos

8- Veräter

jemand, der jemand anderen verraten hat

9- vergaukeln

mit Musik fertig machen

10- Verchecht

vergessen, durcheinander bringen

11- verschlendern

durch Spazierengehen viel Zeit verbringen (wird als negativ angesehen)

12- vernabeln

Kabel miteinander verbinden

13- verreimen

einen falschen Reim bilden

14- verstotter 
durch Nervosität durcheinander bringen

15- Verräcken (Subst)

sterben (von verrecken)

16- verwöhnaromen

ein schöner Duft

17- verranzt

heruntergekommen, verwahrlost

13- Unten steht eine Liste mit 17 Verben, die noch nicht in Wörterbüchern zu finden sind. Es geht um Wörter, die aus HipHop Texten stammen. Schreiben Sie bitte kurz, was Sie unter den Verben verstehen. Sie finden unter jedem Verb den Kontext, in dem es vorgekommen ist und der Ihnen bei der Deutung helfen kann. Sie können auch mehr Informationen über die Texte auf den angegebenen Webseiten erfahren, falls der genannte Kontext nicht aufschlussreich genug ist. Achten Sie darauf, dass einige Wörter schlicht Rechtschreibfehler sein können!

1- verbassen

Das ist ne Wortkreation. Ich schätze er macht aus dem Bass, Musik Bass [engl. bass] ein Verb. Jemanden verbassen... denn danach .... "neue Beats verpasse". Soll sich wohl reimen. Aber dieses Wort gibt es nicht und ist eine reine Kunstkreation.

2- verspeien

Wortkreation, bedeutet im Wesentlichen ausspucken

speien $=$ starkes Verb - a. spucken; b. spucken; c. sich übergeben

ver-

Rechtschreibung Worttrennung: ver- Nach oben Bedeutungsübersicht drückt in Bildungen mit Substantiven oder Adjektiven und einer Endung aus, dass sich eine Person oder Sache [im Laufe der Zeit] zu etwas (was im Substantiv oder Adjektiv genannt wird) hin verändert drückt in Bildungen mit Substantiven oder Adjektiven und einer Endung aus, dass eine Person oder Sache zu etwas gemacht, in einen bestimmten

3- verpeilt

verpeilt (umgangssprachlich):

- $\quad$ durcheinander / vergesslich / in Gedanken / unaufmerksam sein

- Wenn jemand etwas vergessen hat oder so unorganisiert ist, dass er einfach "nix auf die Reihe kriegt".

- $\quad$ Der Zustand, wenn man überarbeitet ist, ganz andere Sorgen hat oder morgens aufsteht. Kommt aus der Seefahrt: Wenn man sich verpeilt, kann das böse Folgen haben nach dem Motto: "Das ist Island, nicht Irland!"

4- verchecken

hat mehrere Bedeutungen:

a) Sachen verchecken: im Sinne von verkaufen

b) Neffen verchecken... keine Ahnung, könnte in dem Zusammenhang vielleicht heißen, ,sie fertig machen, zusammenhauen“... kann ich nicht mit Sicherheit sagen.

5- verächten

Wortkreation:

ächten: schwaches Verb - a. über jemanden die Acht verhängen; b. aus einer Gemeinschaft ausstoßen; c. (als gemeinschaftsfeindlich) verdammen.

also Sünde schlecht heißen, Sünde ist nix Gutes, Sünde muss verdammt werden

6- verkreuzen

das ist einfach beschissenes Deutsch: 
richtig heißt es: .... "kreuzen sich unsere Pfade" oder es kreuzen sich Wege...

7- Verstumpfen

Wieder ne Wortkreation

Kommt von abstumpfen: schwaches Verb - 1a. stumpf machen; 1b. stumpf werden; 2a. gefühllos, teilnahmslos machen

I. (mit Objekt) etwas stumpft jmdn. ab (haben) unempfindlich oder gleichgültig werden lassen "Sein schweres Schicksal hat ihn/seine Gefühle abgestumpft"

II. (ohne Objekt) jmd. stumpft ab (sein) unempfindlich oder gleichgültig werden

Hier: "In der City werden die Leute gleichgültig/teilnahmslos/ nehmen keinerlei Anteil an Dir, Du bist ihnen egal".... so in der richtung

\section{8- Veräter}

könnte einfach nur falsch geschrieben sein genauso wie plicht $=$ Pflicht

Veräter = Verräter: jemand, der etwas verraten, ausgeplaudert hat jemand, der einen Verrat begangen hat, Eine Person, die einen Verrat begangen hat, wird als Verräter bezeichnet

Synonyme

Denunziant, Denunziantin, Judas, Spitzel, Zuträger, Zuträgerin, Zwischenträger, Zwischenträgerin; (Jargon) Zinker, Zinkerin; (Schülersprache abwertend) Petze, Petzer, Petzerin

9- vergaukeln

Wortkreation

Gaukeln: schwaches Verb - 1. leicht und spielerisch schaukelnd schweben; 2a. etwas vorspiegeln, vortäuschen; 2b. Zauber-, Taschenspielerkunst treiben

Vorgaukeln: schwaches Verb - jemandem etwas so schildern, dass er sich falsche Vorstellungen, Hoffnungen macht

Hier: vielleicht im Sinne von verarschen...

10- Verchecht

keine Ahnung

11- verschlendern

Hier: Den Tag lang im Stadtpark herumschlendern

schlendern: schwaches Verb - a. gemächlich, mit lässigen Bewegungen gehen; b. sich schlendernd irgendwohin begeben

12- vernabeln

keine Ahnung. Wahrscheinlich ist dem nix reimendes auf Kabel eingefallen. Sinnvoll wäre hier: verkabeln. ABER Kabel verkabeln klingt auch doof

13- verreimen

Gedichte reimen sich:

Hier: verreimen im Sinne von falsch reimen

14- verstotter

hier: meinen text sotternd lesen

stottern: schwaches Verb - a. stockend und unter häufiger, krampfartiger ...b. (aus Verlegenheit o. Ä.) stockend ...

15- Verräcken (Subst)

ich schätze es ist einfach wieder verflälscht:

die Stätte des Verreckens

verrecken: schwaches Verb - eingehen, elend sterben; krepieren

16- verwöhnaromen 
Es gibt in Deutschland eine Kaffe Werbung: Da heißt es "der Kaffe mit dem Verwöhnaroma". Ist ein zusammengesetzte Wort aus Aroma und dem Verb verwöhnen, was hier adjektivisch verwendet wird. Aroma: Substantiv, Neutrum - 1. ausgeprägter angenehmer Geschmack, würziger Duft; ...2. [künstlicher] Geschmacksstoff für Lebensmittel, aromatisches ... verwöhnen: schwaches Verb - a. jemanden durch zu große Fürsorge ...b. durch besondere Aufmerksamkeit, Zuwendung dafür

17- verranzt

verranzt: abgeleitet von ranzig (butter oder anderes Fett wird ranzig) - meist Umgangssprachlich für verdreckt, gammelig

14- Unten steht eine Liste mit 17 Verben, die noch nicht in Wörterbüchern zu finden sind. Es geht um Wörter, die aus HipHop Texten stammen. Schreiben Sie bitte kurz, was Sie unter den Verben verstehen. Sie finden unter jedem Verb den Kontext, in dem es vorgekommen ist und der Ihnen bei der Deutung helfen kann. Sie können auch mehr Informationen über die Texte auf den angegebenen Webseiten erfahren, falls der genannte Kontext nicht aufschlussreich genug ist. Achten Sie darauf, dass einige Wörter schlicht Rechtschreibfehler sein können!

verbassen

Dieses Wort ist mir bisher im Alltag nie begegnet. Ich vermute, dass das Wort von „Bass“ abgeleitet wurde und so etwas Ähnliches wie „beschallen“ bedeuten soll. Eine genaue Bedeutung zu finden, fällt mir schwer.

verspeien

Ein mir völlig neues Wort. Die Bedeutung kenne ich nicht und erschließt sich mir auch nicht aus dem Text.

verpeilt

Mittlerweile ein relativ normales Wort im deutschen Sprachgebrauch und im Alltag bei jungen Menschen durchaus verbreitet. Es bedeutet etwas zu vergessen/ falsch zu machen oder durcheinander zu bringen.

verchecken

Ein gelegentlich im Alltag benutztes Verb. Es wird im Sinne von „verkaufen“ gebraucht.

verächten

Ein mir noch nie begegnetes Wort. Ich vermute, dass jemand das Wort „,verachten“ geändert hat oder es abgeändert hat, um den Reim besser klingen zu lassen.

verkreuzen

Hier könnte überkreuzen oder so ähnlich gemeint sein. Erneut ein mir noch nie begegnetes Verb. _-

Verstumpfen

Hier könnte „abstumpfen“ gemeint sein. Vermutlich wurde einfach das Verb geändert oder jemand kannte das ursprüngliche Verb nicht.

(Anmerkung meinerseits: Diese Musik wird meiner Meinung nach häufig von Menschen aus bildungsfernen Schichten oder mit Migrationshintergrund geschrieben, welche teilweise der Deutschen Sprache nur eingeschränkt mächtig sind oder die einen speziellen „Slang“ sprechen, der grammatikalisch häufig fehlerhaft ist.

Veräter

Hier ist ein Substantiv gemeint. Der „Verräter“. Ein Schreibfehler und kein neues Verb.

vergaukeln 
Hier ist vermutlich eine Mischung aus „,verschaukeln“ (jemanden veräppeln/ sich über jemanden lustig machen) und dem Wort „Gaukler“ entstanden. Vielleicht könnte in diesem Zusammenhang auch ,schlagen“ gemeint sein. Dieses Wort ist mir ebenfalls nie begegnet im Alltag und die genauer Bedeutung erschließt sich mir aus dem Zusammenhang nicht..

Verchecht

Ich kann mir nicht erklären, was dieses Wort bedeuten soll.

verschlendern

Siehe 7. Hier wurde meiner Meinung nach das Wort „schlendern“ bzw. „,irgendwo entlang schlendern“" abgeändert, kein eigentlich neues Wort meiner Meinung nach. vernabeln

S. 7. und 11. Hier ist meiner Meinung nach „,verbinden“, vermutlich eine Mischung mit „abnabeln“ (sich lösen von etwas/ jemandem).

verreimen

Hier wurde das Wort „reimen“ einfach abgeändert und ihm eine neue Bedeutung gegeben. In dem Zusammenhang steht es für das Gegenteil, also „falsch reimen/ etwas falsch machen beim Erstellen eines Reims“.

verstotter

Siehe 7, 11 und 12. Ableitung vom Wort „stottern“.

Verräcken (Subst)

Ein Schreibfehler und kein neues Wort. Hier ist „verrecken“/ Stelle der „Verreckens“ (Sterbens) gemeint.

verwöhnaromen

In der Werbung seit den 80er/90er Jahren benutztes Wort für Kaffeearoma der Marke „Jacobs“ (Singular „Verwöhnaroma“). Dieses Wort wurde benutzt, um Kaffee und verwöhnen werbewirksam in Verbindung zu setzen. Jeder kennt diesen Begriff.

verranzt

Das Wort wird manchmal umgangssprachlich für „ungepflegt sein/ schmutzig sein“ verwendet. Ich empfinde es jedoch als ein sehr derbes Wort und verbinde es eher mit niedrigem Bildungsstand. In dem Zusammenhang des Textes ergibt es jedoch nur teilweise einen Sinn.

15- Unten steht eine Liste mit 17 Verben, die noch nicht in Wörterbüchern zu finden sind. Es geht um Wörter, die aus HipHop Texten stammen. Schreiben Sie bitte kurz, was Sie unter den Verben verstehen. Sie finden unter jedem Verb den Kontext, in dem es vorgekommen ist und der Ihnen bei der Deutung helfen kann. Sie können auch mehr Informationen über die Texte auf den angegebenen Webseiten erfahren, falls der genannte Kontext nicht aufschlussreich genug ist. Achten Sie darauf, dass einige Wörter schlicht Rechtschreibfehler sein können!

verbassen

prägen, manipulieren

verspeien

${ }_{\text {verpeilt }}$ verarbeiten

_verplanen,vergessen

verchecken

_a)verkaufen

b)verkuppeln_ 
verächten

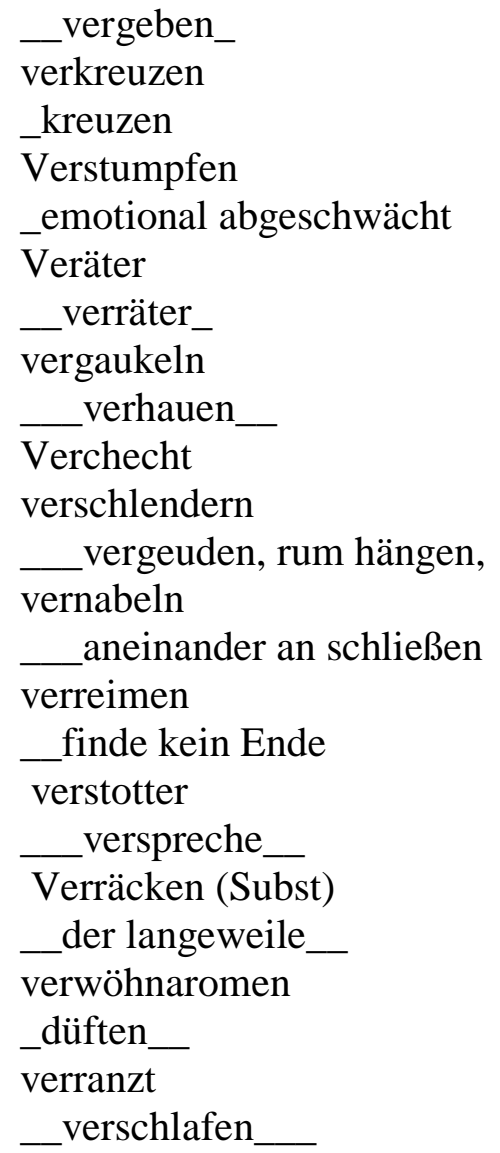

16- Unten steht eine Liste mit 17 Verben, die noch nicht in Wörterbüchern zu finden sind. Es geht um Wörter, die aus HipHop Texten stammen. Schreiben Sie bitte kurz, was Sie unter den Verben verstehen. Sie finden unter jedem Verb den Kontext, in dem es vorgekommen ist und der Ihnen bei der Deutung helfen kann. Sie können auch mehr Informationen über die Texte auf den angegebenen Webseiten erfahren, falls der genannte Kontext nicht aufschlussreich genug ist. Achten Sie darauf, dass einige Wörter schlicht Rechtschreibfehler sein können!

verbassen

die Menschen kirre machen

verspeien

spucken

verpeilt

etwas durcheinander bringen

verchecken

überprüfen

testen

5- verächten

verachten 
6- verkreuzen

treffen

7- Verstumpfen

ohne Interesse für andere, jeder für sich

8 - Veräter

Verräter

9- vergaukeln

verzaubern

10- Verchecht

vergesst (es)

11- verschlendern

Nichts tun

12- vernabeln

Kabel zusammen stecken

13- verreimen

etwas falsch reimen

14- verstotter

versprechen

15- Verräcken (Subst)

sterben

16- verwöhnaromen

ein Duft, der an die Kindheit erinnert

17 - verranzt

ungepflegt, ungewaschen

17- Unten steht eine Liste mit 17 Verben, die noch nicht in Wörterbüchern zu finden sind. Es geht um Wörter, die aus HipHop Texten stammen. Schreiben Sie bitte kurz, was Sie unter den Verben verstehen. Sie finden unter jedem Verb den Kontext, in dem es vorgekommen ist und der Ihnen bei der Deutung helfen kann. Sie können auch mehr Informationen über die Texte auf den angegebenen Webseiten erfahren, falls der genannte Kontext nicht aufschlussreich genug ist. Achten Sie darauf, dass einige Wörter schlicht Rechtschreibfehler sein können!

verbassen

Bass von der Musikbox aufdrehen und auf die Menge halten verspeien

verteilen_

verpeilt

was falsch machen

verchecken

a) verkaufen 
b) abfertigen

verächten

verachten

verkreuzen

kreuzen

Verstumpfen

stumpf werden

Veräter

Verräter

vergaukeln

Vergraulen

Verchecht

???

verschlendern

herumschlendern

vernabeln

verkabeln

verreimen

ich reime nicht richtig

verstotter

ich stottere nicht richtig

Verräcken (Subst)

sterbens

verwöhnaromen

Faktoren die einen verwöhnen

verranzt

abgenutzt 


\section{Anexo III - Letras de música}

Artista: Absolute Beginner

Almbum:Bambule

Faixa: Rock On

Ob es weh tut oder nicht, im Portemonaie / ich investier' in die Beginner A.G. / So steigt mein Wortwert, mein Style wirkt doller/die Fans wollen uns, wie die an der Börse Dollar / HipHop Tracks fallen im Kurs, wie uns Ideen ein / so tun wir Mr. HipHop ein' Gefallen und füllen Hallen / in denen wir abstylen ,immer weiter“ / die Karriere sucht ' $\mathrm{n}$ Job, als Sprosse in der Tonleiter / mit Hemd und Schlips nach oben ist kein Clou / denn klettern ist Sport, brauch ein Paar Turnschuh' / jeden Tag seh’ ich sie, doch sie blicken nicht mehr / "was geht", schauen nur auf die Uhr, doch ticken nicht mehr / gefesselt am Schreibtischsessel haut sie nichts vom Hocker / sie wären gern- doch sind bloß ihre Schrauben locker / Ihr Leben ist verplant, denn sie waren planlos / Wir ham' kein Ziel, aber wir fahren los / Die Beginner als Job, tausend Styles im Gepäck / Verträge unterschreib' ich mit'm tag / Die Welt geht kacken, doch vorher werd' ich Styles kicken/und mit den Beats bumsen und mit'm Funk ficken ...

Refrain: Wir sind am Start und die Welt ist groß / Wir ham' kein Ziel, aber wir fahr'n los / unser Zug ist abgefahr'n doch wir sitzen drin / Niemand kann ihn stoppen, wir werden weiterrocken ...

Ich verbasse die Masse, indem ich ihr neue Beats verpasse / Krieg' dafür Geld, daß ich auf'm Kiez verprasse / oder im Plattenladen, wo sie Rap Platten haben / denn nur Rap Platten schützen mich an nassen Tagen / Aus meinen Raps daraus, bau ich mir ein Haus / gegen Hunger hab' ich einen Kühlschrank voll mit Applaus / Ich seh' die Welt, und sie sieht den Eißfeldt / habe Spaß nicht nur am Dienstag, penn' aus während ihr Dienst habt / Und komm' mir nicht mit BMW und GTI, Lamborghini und Ferrari / mit New York Hardcore Rap auf'm Ohr, mit'm Bike, bin ich zwanzigmal so schnell wie die / Immer motiviert durch Unsympathen aller Arten / die Luft für mich sind, aber Luft, die ich atmen / muß, denn ich will überleben / nicht ersticken in dem Mist, den sie ständig reden / immer hinter mir, Masen von Kollegen / die, wie ich, die Ärsche der Nation bewegen / Wir leben und rocken und niemand kann uns stoppen / Wir werden aller Popper foppen und die Charts toppen ... 
Refrain: Wir sind am Start und die Welt ist groß/Wir ham' kein Ziel, aber wir fahr'n los/unser Zug ist abgefahr'n doch wir sitzen drin/Niemand kann ihn stoppen, wir werden weiterrocken ...

Eure Welt glänzt 25 mal in der Sekunde, aber meine Augen sind geschlossen / elfte Runde und ich flash, bis ich umfall / flash auch unprall! / wenn ich die Karstadtwelt stumm schalt' / nicht um- sondern ausschalt' / wann immer ich Bock hab', den Mund halt, Bassdrumaus'm Auto rausschallt / Bongblast mit Vollgas in's Gehirn knallt / selber Drogen kaufen, anstatt Miami Vice gucken / in Gedanken noch jedem Bullen ins Gesicht spucken / Tanz' weder euren Walzer, noch Disco Fox / ich nick' nur mit dem Kopf zum Rap, der aus der Box kommt / Der JBL-Boom, mit dem ich Nachbarn umlege / den gute Boxen kennen keine Mietverträge / Ich lebe und liebe die Bilder und ihre Macht / Blinzel' nach einer durchgemachten Nacht in die Sonne / Du willst Wein, Lady? Du willst Dinner, Lady? / Wie wär's mit China-Imbiß, a la Beginner; Baby? / Mich scheucht keiner irgendeinen Weg lang / Ich bin Beginner man, irgendwas fang ich immer an ...

Refrain: Wir sind am Start und die Welt ist groß / Wir ham' kein Ziel, aber wir fahr'n los / unser Zug ist abgefahr'n doch wir sitzen drin / Niemand kann ihn stoppen, wir werden weiterrocken ...

Sei’ doch mal ehrlich, du bist zwar überhaupt nicht locker / doch ich weiß, tief in dir drin, wärst' du doch auch gerne 'n Rocker / Du ziehst dir doch heimlich auch mal 'ne Daunenjacke an / und schließt dich ein auf'm Klo und hörst Rap Radio, oder guckst Yo!

Artista: Azad -

Faixa: Mentale Krisen feat. Chabs (Jonesman und Jeys)

Ich bin sehr verwirrt und dürste nach Klarem.

Es ist ätzend, ich fühle nur hartes.

Ey, nix zu essen, ich spüre es im Magen.

Muss mich hetzen über Hürden des Tages.

Mich immer stressen, wofür das alles?

Brauch Bares, kein Flash und Loby hält mich auf Low Key

und drückt mich zu Boden. Was'n Fuck aber Hip Hop hält mich oben. 
Ey mann, mein Kopf fickt mich immer schlimmer, wenn ich aufwach' und bis ich einschlaf',

Auch wenn ich nachts wach sitz', nass geschwitzt und Fakt in mein Reim trag. weil 'ne Welt über mir einbrach. Depp, wenn ich sage wie's ist und ich schwör' darauf, das Leben ist bitchig und robbt mich klarsichtlich richtig und es hört net auf. Ich leb' in diesen gefuckten lauen Tagen hinter 'nem Zaun mit Graben und fick das System in dem extrem Probleme und Schmerzen anschwellen. Geh meine eigenen Wege und leb' so genanntes freies Leben in Handschellen. Meine Gefühle peitschen üble Zeichen, zeigen nach unten lang Richtung Abhang in die Tiefe in 'nen ziemlich dunklen Grunde, Mann.

Bin beschissen am krebsen, weil's ein finsterer Weg ist.

Meine Sicht beschlägt sich, ohne Licht, denn es regnet.

Es disst und es quält mich vom bepissten Erlebnis, such' Richtung vergeblich, an 'nem Punkt der dreht sich, steck im Sumpf und es geht nicht.

Chorus: Jonesmann $(2 \mathrm{x})$

Mentale Krisen bringen uns zum entgleisen, zwingen uns laut zu schreien.

Das Klingen von traurigen Geigen wiederspiegelt unser Leiden, aus deepen Zeiten, über die wir Lieder schreiben, die tiefer schreiten, unsere Heat verspeien (2), den Krieg fighten, verwirrt treiben, bis die Krisen schweigen.

Zweite Strophe: Jeyz

Ich steck zwischen Frust und lauter Fragen. Schreckliche Luft um aufzuatmen. Wann ist endlich Schluss? Kann es kaum erwarten.

Wann verlässt mich die Furcht vor grauen Tagen. Um genauer zu sagen, es zerfetzt mich, aber ich muss halt die Trauer ertragen, die auf Dauer nur schaden, deine Power entladen, sich düstere Schauer ergaben, die mich laufend begraben, mir wird die Schlucht bewusst neben Haufen klagen. Seh' meinen Eltern an ihren Augen an, wie sie dem Schicksal grausam erlagen. Sich raufen und schlagen, durch Probleme, die sie andauernd nur plagen.

Sich Schmerzen zufügen, die Scherben genügen und im Enddefekt bedauern sie ihre Taten.

Also lindern wir das Leiden und treten aus den Finsteren Zeiten.

Beten, dass wir das Schlimmste überwinden, um den nächsten Schritt zu beschreiten. 
Den Shit zu vertreiben, versuch meine Geschwister in eine Richtung zu leiten.

In der Licht scheint von allen Seiten, aus meiner Sicht is' es Pflicht mich durchzufighten.

Und seit dem Tag, den ich verfluchend oft im Bett weinend lag.

$\mathrm{Zu}$ hart, ruht seit lange in einem Grab,

ich mach mir Mut neben Schlangen, die ich nicht mag,

Wut, die ich gefangen in mir trag, weil er vermutlich gewaltsam erlag.

Ich mein Fäuste balle zum Schlag und auf die Leute kacke die ich nicht mag.

Chorus: Jeyz $(2 \mathrm{x})$

Mentale Krisen bringen uns zum entgleisen, zwingen uns laut zu schreien.

Das Klingen von traurigen Geigen wiederspiegelt unser Leiden, aus deepen Zeiten, über die wir Lieder schreiben, die tiefer schreiten, unsere Heat verspeien, den Krieg fighten, verwirrt treiben, bis die Krisen schweigen.

Dritte Strophe: Azad

Mein Herz sprudelt aus Cuts, blutet auf's Blatt, ich bin brutally fucked.

Versuch mich zu fangen, bin schon zu tief versackt.

Meine Wut nimmt nicht ab, denn der Frust gibt ihr den Schub und die Kraft.

Bin unruhig bis nachts, wenn der Sooby nichts hat und die Glut nicht entfacht.

Bin ich nicht betäubt und spüre alle Schmerzen würde grad' zerbersten.

Fürchte, dass es mehr sind als ich tragen kann es überfährt mich.

Wohnung mit Kakis, mein Magen hohl und es plagt mich,

mein Vadder auf Drogen und ich frag mich: "Verdammt! Wieso immer grad ich?"

Das Leben ist 'ne Nutte und dann bist du tot, deswegen sind, wenn ich sterbe, beide Mittelfinger oben und meine Augen rot.

Die Krisen ficken meinen Kopf, ich fühl' mich zum Kotzen,

meine Ex ist ne Fotze und nur einer von vielen Gründen, warum ich Türen einbox'.

In mir ist Krieg, es zwingt mich in die Knie. Manchmal denk' ich

ich scheiss auf alles, geh' zu der höchsten Brücke und spring' in die Tiefe.

Das klingt ziemlich mies und geht zu weit. Es tut mir leid,

beschwer' dich bei der Realität, denn das sind Ryhmes die das Leben

schreibt.

Chorus: Azad (2x)

Mentale Krisen bringen uns zum entgleisen, zwingen uns laut zu schreien. 
Das Klingen von traurigen Geigen wiederspiegelt unser Leiden, aus deepen Zeiten über die wir Lieder schreiben, die tiefer streiten unsere Heat verspeien, den Krieg fighten verwirrt treiben bis die Krisen schweigen.

"Wir sind verloren in einer Welt, die uns mit Sorgen überfällt"

"Wir sind verloren in einer Welt, die uns mit Sorgen überfällt"

"Wir sind verloren in einer Welt, die uns mit Sorgen überfällt"

"Wir sind verloren in einer Welt, die uns mit Sorgen überfällt"

\section{Artista: Curse}

Album: Feuerwasser / Jive Rec. / 2000

faixa: Entwicklungshilfe

Ich brauch viel Zeit allein, tauch meinen gesamten Raum in Rauch ein.

Mit beiden Beinen am Boden bleiben, trotzdem im Geist erhoben sein:

Balance kann schwer sein. Fühl meine Nerven um Hilfe schreien,

wenn Scherereien versuchen mein friedliches Dasein aufzureiben.

Ich kann mich nur in begrenzte Seiten aufteilen,

also seid mir nicht böse, wenn ich bisweilen mal was verpeil'.

Ich will niemanden reizen, mich mit niemandem streiten,

doch die meisten Menschen genießen es scheinbar, mich dazu anzureizen.

Und wenn ich dann damit anfang mal auszuteilen,

schreien tausende Typen auf und sind froh, denn sie können mit Fingern zeigen.

Zerreißen sich ihre Mäuler, um mich zu peinigen,

meine Auswahl an Wegen ist den harten oder den steigen.

Trotzdem ist alles zum Wohlgefallen unseres einigen,

einzigen, heiligen, geistigen Konstrukteur alles Seienden.

Doch ich versteh den Bauplan noch nicht und trink Heineken,

und freu mich das einige gibt, die in Liebe bei mir sind.

Ich weiß, Ihr könnt nicht immer bei mir sein,

und nur Gott allein ist mein Licht, doch Ihr weiht mich in sein Geheimnis ein.

Und wenn Ihr bei mir seid im Geist allein,

seid Ihr die Sonne die scheint, Himmel der weint, Boden für meinen Keim.

Ich weiß nicht, wo ich beginnen soll mich zu finden im Dunkeln, 
im Dschungel von meinem eigenen Geiste wo Stimmen munkeln.

Speicher Infos in Akten, sortierte Daten und Fakten, die Wissen entfachen, doch irgendwie trotzdem nicht glücklich machen.

Füll' Wissenslücken mit Sachen, die die Meisten nicht kennen, was es erschwert mich auf normalen Wellenlängen zu verständigen.

Ständig in Turbulenzen an den geistigen Grenzen, will zuviel und tu zuwenig für die echten Essenzen.

Muß erkennen, was es heißt, auch mit dem Herzen zu denken,

Gedanken zu lenken, auf das sie mich mit Freude beschenken.

Beschränken auf das Wesentliche: meines Wesens Mitte, verstehen der Stimme, die irgendwo sein muß in meiner Stille.

Doch glaub' ich hab mich selbst verloren,

meine Verbindung zum Göttlichen nicht gefunden, bin analytisch geworden.

Zuviel in Worten, zuwenig in Gefühlen erwartet,

weiß ich zwar alles über Prana, doch spüren kann ich nur Atem.

Ich glaub', ich lieg' im heiligen Krieg

mit mir selbst, und ich hoffe, daß das Geistige siegt,

daß mein Haß meiner Liebe, Zweifel Weisheit erliegt,

deswegen fall ich auf die Knie und danke Allah, daß er mir Kraft verlieh.

Ich weiß, Ihr könnt nicht immer bei mir sein,

und nur Gott allein ist mein Licht, doch Ihr weiht mich in sein Geheimnis ein.

Und wenn Ihr bei mir seid im Geist allein,

seid Ihr die Sonne die scheint, Himmel der weint, Boden für meinen Keim.

Artista: D-Flame ft. Elephant Man

Album: Basstard

Faixa: Wer / Who

[Elephant Man]

A wich little Boy mi hear no like we

[D-Flame]

Wer 
[Elephant Man]

A wich fassyhole mi hear a chad wi

[D-Flame]

Awhoo

[Elephant Man]

A wich ina Mill mi hear no like we

tell them come after wi name and low we

After now we mek dem pitney a dead fi hungry

come afer we name and low we

After now we mek Capleton bun dem daily

[Verse 1 : Elephant Man]

Bun dem out dem done get Banned me Beat dem up

rubbish band mi broke the food pup the hand

left the and gone to man cant comepare

with Elephant man the girl them mi them number one

gimme patsy gimme Pam reva Road all night long worster

than a Stallion mek she ball fi belly bottom Elephant man

and Flames the Don you know we are the number one

Girl them say them love Slang when them see mi sing that one

here number one pon the Billboard ha

[Verse 2 : D-Flame]

Selbst deine Mutter hört meine Stimme und Schmilzt

direkt wie Butter kann dir sagen wie nass deiner

Freundin ihre Futt war erst gesern abend haben

wir uns beschnuppert und sie nennt mich ihren Braunen Zucker

guckmal du hast einen gut bezahlten Job als Drucker trozdem

zieht deine Chica lieber an meiner Hukka sie braucht mich wie

ich mein Hirnfutter und du Stinkst immer noch wie ein Fischkutter.

[Verse 3 : Elephant Man]

Elephant man the Dapper and Mr. flamez the Big Pappa

mek girl sit down ina me lappa Elephant the Dapper

and Mr.Flamez the Big papa and the girl them say we are them Slappa

Elephant Man the dapa and mr flamez the big papa 
yes we work the girl dem Proper

Elephant Man the dapa and Mr.Flamez the Big papa

mek Girl bust like Fire Ey so mi say

a wich Fassyhole mi hear no like we a wich ina mill

mi hear a chad we a which little Boy we hear

no like we tell them come after we name

and low we you know after now we mek them pitney a dead

fi hungry come after we name and low we after now we mek greed

and no follow them monthly ey Mr.Flamez Dj.

[D-Flame]

Sogar ihr Vater liebt meinen Style und wär gern mein Papa

vercheckt seine Plattensammlung inklusive Abba

trägt aufeinmal Trainingsanzüge von Kappa

und sieht jetzt lieber Yo statt Tappert

[Verse 4 : Elephant Man]

Bun dem out dem done get Banned

me Beat dem up rubbish band

mi broke the food pup the hand

left the and gone to man cant comepare with Elephant man

the girl them mi them number one gimme patsy

gimme Pam reva Road all night long worster than a Stallion

mek she ball fi belly bottom Elephant man and Flames the Don bring it to me number one and this is a billboard song everywhere we go the Girl them say Elephant and Flamez.

A which little fool mi hear no like we /Wer

A which posse yes neva rait we / awhooo

A which little Boy mi hear a chad we

tell them come after we name and low we

After now we mek the pitney a dead fi hungry

come after we name and low we

after now we mek greed and na follow them monthly

come after we name and low we

after now we mek capleton a bun dem daily 
come after we name and low we

after now we mek them album na sell grammy

come after we name and low we

[D-Flame]

Geschnatter hinter seinem rücken ist ihm egal weil die kacker

im leben eh nicht weiterkommen als Packer

während er im Wohnzimmer meine texte nachblappert

will die tochter das ich an der brust knabber

[Elephant Man]

tell them say no fight it when that tune here bust

mi sey nobody fi stop it

Elephant Man Flamez the whole City we lock it

stage show keep on all the Club them jampacked

yo cool platinum we a go sell it ice pun mi hand

and mi no see nobody fi melt it

love fi dee the girl them ina leather and velvet and you know se that elephant man hafi you know se mi want hold her and date it

A Which fassyhole...

Artista: Spiritual Warriors

Faixa: Grüner Tee feat. Curse

\section{Vers Eins}

Frag meine Königin nach mir, Curse ist König im Rap- Revier.

Ich versöhn' mich mit dir bei König Bier, klön bis es persönlich wird.

Burn mich, das gönn' ich dir vorerst, doch natürlich: man hört von mir.

Engel tragen schon jetzt Kundschaft von der Wunderkraft die mein Körper birgt.

Die Hundertschaft Wörter wird euch in Gottes Preisung,

enthüllt als Unterweisung in Geisterheilung, Weisheit nach meiner Meinung.

Doch das sei nicht euer Richtwert, der eure Sicht klärt,

und trotzdem teil ich euch durch mein Lichtschwert als wenn ihr nichts wärt. 
Hör auf mein herz und reduzier' die Drogen,

denn ich hab zwei freunde verloren an cannabis induzierte Psychosen.

Manchmal denk ich das Wesen oben will uns testen,

und checken ob wir auch jetzt in den letzten tagen die Wahrheit sprechen.

Sünde verächten und gerecht unsere Brote brechen,

Gebote sprechen, Leichen im Geiste aus ihrer not erwecken.

Ich soll nicht sprechen wenn's nicht wichtig ist,

und deswegen red ich soviel und oft weil in jedem Satz meine Seele spricht.

Hook

Seit die Erde sich dreht denkt sich jeder er weiß was geht,

der Kreis entsteht, denn man erntet das was man sät.

Die Qualität, ist abhängig von wie man's pflegt,

ich kümmer' mich um den Garten und warte bei grünem Tee.

Vers zwei

Ihr seid im Zugzwang, mein China Wu-Jan zieht zwei Minuten lang,

dein Schweinemedallion fühlt sich blutig an, man versucht sich dran und läßt es.

Weil alles was mästet wahrlich wie pest ist,

bevor Salami auf meinem Tablett ist fress ich Aspest Chips!

Das beste ist: Salate, Kartoffeln für Kohlenhydrate, Brot und viel Reis, das heißt ausgewogen und vitaminreich.

Mein Team weiß beste Rezepte für frische Säfte,

die Küchenchefe vermischen Gemüse und Obst in Früchtepressen.

Laß mir Sojasprossen genüßlich schmecken,

beim gemütlich essen werden Sachen die Stressen müßig vergessen.

Nicht von Müsli Typen, die in Birkenstocks über Büchern brüten,

sondern von würdigen Tai-Chi meistern die Weisheit hüten

laß ich mich leiten meinen Geist zu üben, weiter über Rhymes zu brüten,

Neider zu meiden und nur mich selbst zu rügen.

Man sagt die Augen sind die Schlüssel zur Seele,

und die Ernährung sei die Brücke zwischen Geist und Materie.

Hook

Vers drei

Sieh's realistisch: Milleniumswechsel sind anarchistisch, 
allein die Feststellung das es uns Menschen berührt ist wichtig.

Vergiß nicht, geschichtlich richtig ist als erster Fakt,

das zu Jahrhundert- und Tausendwenden das Endzeitdenken entfacht.

Und drüber nachgedacht ist es eigentlich scheißegal ob das zutrifft,

weil Glaube allein schon meistens genug ist damit das Blut spritzt.

Da alles sich zu spitzt, es Menschen mehr als genug gibt,

wehrt die Natur sich biologisch bis keiner vor AIDS immun ist.

Selbst Schlagworte wie Ozonloch und Treibhauseffekt sind gags,

wenn das Datennetz alle wichtigen Koordinaten trasht,

und Bin-Laden's Kohorten A-Bomben horten und knöpfe drücken,

bis Paranoia und Chaos in unsere köpfe vorrücken.

Mit größtem entzücken, füll ich wissen in bloße Lücken,

aber pos' nicht auf stücken als würd' meine Sicht sich mit Wahrheit schmücken.

Sicherlich wissen die meisten vielmehr als ich,

ist nur ärgerlich: ich hör tausend Rapper reden und merk es nicht!

Artista: Curse

Album: Von Innen nach Aussen / Jive Records / 2001

Faixa: "Viel leichter"

(ja, mhh, yoah, wer den Song hier wack findet, weil er zu smooth is

- der is $\mathrm{n}$ armer Wichser, der nicht zugeben kann, dass er Gefühle hat, ai)

[1]

Ich würd mein Augenlicht geb'n um Dich zu sehn

Gern meine beiden Beine verlier'n um in Deinem Leben zu geh'n

Scheiß auf's Rap-geschäft, ich wand're aus

Und wenn wir keinen Platz zum Schlafen haben, dann crash ich bei Bekannten zu Haus

Hab keine Sorgen, denn wir schaffen das schon

Du und ich gegen die Welt, aber wir machen das schon

Wenn kein Essen und Trinken auf uns'rem Tisch is, weil das Geld zu knapp is

Wir gehn ins Bett, halten uns fest und vergessen es denn ich hab Dich

Will niemehr an was and'res denken

Niemals meine Seele\&Vetrauen jemand anderem schenken 
Ich will niemehr Deine Nähe vermissen

Nichts is besser als Chicken, Amanda und Krüge für Reis aus Deiner Kitchen

Du musst niewieder allein' auf mich warten

Ich bin bei Dir heut Nacht, nichts ist schöner als neben Dir einzuschlafen

Ich lieb' Dich über alles in der Welt

Ich will Leben und Sterben mit Dir teilen, doch wer weiß...

$\operatorname{Hook}(2 \mathrm{x})$ :

Vielleicht geht's Dir besser ohne mich

Vielleicht ist Dein Leben ohne mich, viel leichter oder nich

Wenn Du weißt was Du willst, bin ich der Letzte - der Dich stoppt

Ich will nur wissen, dass Du weißt, dass ich Dich schätze

[2]

Du gibst mehr als ich, Liebe und Gott sind erklärt durch Dich

Du rettest mich, ohne Dein reines Herz hätt' ich nichts

Ich fall immer wieder auf die Knie, fleh zu Gott,

dass ich Dich lieben darf und nie verliere

Und ich wein mir meine Seele aus dem Leib, weil ich Dich so vermisse

Schrei Deinen Namen nachts in meinen Träumen, heul in mein Kissen

Wart' auf ein Wort von Deinen Lippen

Nur ein Lächeln, nur ein Nicken, nur eine Berührung, nur ein Bißchen

Ein $\mathrm{Ku}$ ist alles um mein Leben zu retten

Ich brauch nichts mehr und niemanden sonst, doch wer weiß...

$\operatorname{Hook}(2 x)$ :

Vielleicht geht's Dir besser ohne mich

Vielleicht ist Dein Leben ohne mich, viel leichter oder nich

Wenn Du weißt was Du willst, bin ich der Letzte - der Dich stoppt

Ich will nur wissen, dass Du weißt, dass ich Dich schätze

[3]

Jeder Tag war durch Dich gesegnet

Jeder Augenblick ewig, jeder Atemzug Nahrung für meine Seele

Durch Deine Nähe kam Nähe zu Gott

Ich verstand, dass mein Herz mich mehr leiten soll, als mein Kopf

Vielleicht war es Deine Mission von der Du immer gesprochen hast 
Das Herz erst zu befreien, das Du dann später gebrochen hast

Das Ganze entzieht sich der eingeschränkten Verständnis

Du weißt wahrscheinlich genauso wenig wie ich warum Liebe, wie diese endet

Warum Menschen sich finden und ganz ohne Grund verlier'n

Das is himmlische Fügung ohne Vernunft

Für die Zukunft fragst Du Deine Karten und ich muss warten

Wenn's im Plan von Allah ist verkreuzen sich uns're Pfade

Denn nächstes Mal ist vielleicht alles leichter, wir sind weiter

Ham' mehr gesehn und mehr Basis für Zeit gemeinsam

Mir scheint wir vereint könnten Frieden für Welten finden

Doch vielleicht müssen wir beide uns vorher erst selber finden

[selber finden, selber finden...]

$\operatorname{Hook}(2 x)$ :

Vielleicht geht's Dir besser ohne mich

Vielleicht ist Dein Leben ohne mich, viel leichter oder nich

Wenn Du weißt was Du willst, bin ich der Letzte - der Dich stoppt

Ich will nur wissen, dass Du weißt, dass ich Dich schätze

[ja...ja]

Artista: Deichkind

Album: Bitte ziehen Sie durch / Showdown / 2000

Faixa: Smogcity

Refrain: $2 \mathrm{x}$

In der City stehen Betonblocks.

Wir atmen Smog ein.

In der City stehen Betonblocks.

Wir atmen Smog ein.

Die City stresst mich.

Philipp:

Ich hab die Augen weit geöffnet, immer auf der Hut wie 'n Dschungeltier, wenn du den Mut verlierst ist das herzlich dumm von dir, denn in der City musst du durch, Leute verstumpfen hier 
jeder geht an dir vorbei, undurchschaubar wie Dunkelbier.

Ich weiss nicht den Grund dafür, vielleicht sind zu viele hier, die meisten sind überfordert für 'n einfaches: Ick liebe dir!

Hauptsache die Welt ist connected über T-Online,

Emotionen werden kalt, werden härter als Betonstein.

Malte:

Denn inner City in der ich wohn' da stehen Betonblocks,

Smog burnt meine Nase, wenn ich vom Balkon glotz.

Die Leute gehen, wissen nicht wo die Bremse ist, scheissegal ob Hamburg oder Los Angeles.

Ich bin verwirrt wie Al Bundy, wenn Frauen die Brüste wedeln, der Smog der City ist undurchschaubar wie Küstennebel.

An manchen Tagen brauch ich 'n Krankenwagen,

in der City gibt es wenige die auch mal danke sagen.

(Refrain: 2x)

Buddy:

Ich setz mein' Fuss vor die Tür, schwimm im Strom.

Spür ich bin gefangen im Citysyndrom.

Die meisten sind so rücksichtslos wie Klingonen.

Ich hab die neusten Tapes an Bord. Wechsel stätig meinen Standort.

Sag ständig Hallo, doch krieg keine Antwort.

Das Citysymtom: Es sagt keiner Hi.

Leider bleibt in der Stadt für Guten Tag keine Zeit.

Menschen bist du einerlei. Sie laufen an dir vorbei,

überall und immerwieder derselbe Einheitsbrei.

Philipp:

Eigentlich komm ich damit gar nicht klar.

Ich war nicht da als die das gebaut haben, als das noch alles Botanik war.

Hier wird zuviel gebaut, zuviel Lärm und fertige Typen,

da werd' ich gleich wütend, wenn die mich nicht ehrlich begrüssen.

Bei so 'nem Style möchte man doch glatt 'ne Reise buchen, 
bei heftigem Dreck und Strichern die nach Freiern suchen.

Und keiner wird den Leuten helfen die im Siff liegen,

denn leider wird das Ganze hier keiner in 'n Griff kriegen.

(Refrain: 2x)

Malte:

Als ich hierher kam, hat es mir anfangs gefallen,

wenn ich heut' schlaf träum ich von Sandstrand mit Palmen.

Denn da draussen sind die Jobs, die Leute und Termine,

muss immer daran denken, wie und wann ich was verdiene.

In Smogcity ist alles zugebaut,

der falsche Platz, wenn ich 'ne ruhige Minute brauch'.

Da hilft kein Wimmern und für 'ne bessere Zeit beten,

du musst die City lieben lernen wie Bäcker Teig kneten.

Buddy:

Wenn ich mich in der Stadt in den hektischen Wahn stürze, dreh ich durch wie 'ne elektrische Zahnbürste.

Ich muss mein Leben, die Zukunft und das Geld regeln, was würde ich hergeben könnt ich einfach um die Welt segeln.

Stattdessen muss ich mich vertragen mit den Psychopathen, die an meinen Nerven nagen wie abends die Küchenschaben, an üblen Tagen kannst du kein Schritt machen, wie im Bus Insassen, fühlst dich wie Innercitykids im Schwitzkasten.

(Refrain: 2x)

Artista: D-Flame

Album: Basstard (2001 / Eimsbusch Basement)

Faixa: Wo sind wir daheim feat. Tone, Chabs, Real J

2x Hook (D-Flame)

Der grund das sie uns Stoppen wollen kann nur Angst sein

hinter dem Rücken reden und dann kurz Anschleimen

jetzt sind wir bereit und man kann gespannt sein

wo sind wir daheim ? Frankfurt am Main 
(Tone)

Wir werden Idioten Stoppen ungespitzt in den Boden stopfen so zeroppen wie Robocop weil die Flows so bekloppt sind ich krieg ein Hochroten Kopf das verlogene gesindel lobt uns hoch in den Himmel dabei wären sie ober froh wenn wir Floppen

(D-Flame)

Yo Tone ich kenne die abgefuckten Blicke von Enemys könnten sie Töten wären wir lange weg wie Kennedy doch irgendwie geben genau sie neue Energie und zeigen das wir auf dem richtigen Weg sind mit der Family.

(Jeyz)

Meine oberste plicht represent meine Familie denn ohne gehts nicht und seit dem ich Mikrofone ergriff über Scenes wo ich wohne bericht brauch nur Homiez um mich all die Hater und veräter macht ein bogen um mich ihr seit verlogen wie nichts sorg für wirbel in deinem Viertel alter ich scheiss auf so ein Geschiss. $($ Real J)

Die Hessische schnude kommt lässig wie`n Lude mit Bässen die Boomen direkt in deine Fresse net durch die Blume wir sind im Studio am Brennen und du nur am Pennen wirst erwachen erkennen net mehr lachen nur flennen weil wir sachen zersprengen.

2x Hook (D-Flame)

Der grund das sie uns Stoppen wollen kann nur Angst sein hinter dem Rücken reden und dann kurz Anschleimen jetzt sind wir bereit und man kann gespannt sein wo sind wir daheim ? Frankfurt am Main (Jonesmann)

Werd mir die Deppen vornehmen direkt die Form sprengen mit stärke vordrängen lass raps zum song bangen Nordweststadt wortslang werd bis ans Ende ziehen represente ihn mit meiner Click an meinen Shit der kleinen Bitern gibt hey von denen kommt net einer mit.

(Tone)

Auf unserem Speiseplan stehen arme M.c`s die nicht fleissig waren die meisten kamen unberschreiblich Arm weil sie peinlich waren die Styles sind zu lahm wir begeistern mit wahren Mördermetaphern zerstören damit Affen unsere Wörter 
sind waffen die wir Meisterlich planen.

(Real J )

Wir sind ein ganzer verdammter Trupp von Frankfurter Panzer zerstanzer die langsam deine Stadt unterwandern werden dich immer wieder mit diesen Liedern verbrennen deine miesen Glieder zertrennen das dich Mediziner nie wieder erkennen. (D-Flame)

Gegen Jeyz, A-Bomb, Tone, Flame und zweimal Jones kommt ihr nicht an auch wenn ihr jeden von uns Dreimal klont gibts immer wieder auf die Backen denn ihr seht schon auf MTV oder Viva aus wie Lappen.

2x Hook (D-Flame)

Der grund das sie uns Stoppen wollen kann nur Angst sein

hinter dem Rücken reden und dann kurz Anschleimen

jetzt sind wir bereit und man kann gespannt sein

wo sind wir daheim ? Frankfurt am Main

(Jeyz)

Weil mein Herz mit Stolz zu mir spricht noch ist es düster aber ich folge dem Licht voll zugekifft mit meinen Brüdern so wie ich schon immer wollte ansich und täusch mich auch nicht da ich sowieso auf falsche Freunde verzicht sehe es einem sofort im Gesicht an und weiss auch wer sich vorort verpissen kann.

(Jonesmann)

Weil von euch leider keiner Blickt was ich fühl wenn ich Reime kick nix ist kühl denn ihr seit gefickt wenn ich glüh und die Reims verschick ich geb mühe ihr reitet Dick denn wir rollen Fett wie Playas wixer ihr seit wack und jeder siehts hier ein smack der fürs leben ist.

(Tone)

Jetzt bist du gedoggt denn der Wortfetischist der disst dich sofort noch befor du es Blickst denn die Tricks sind enorm und durchbohren dich wie nix. (Real J)

Ich komm in deine Gaderobe laber dich in Grund und Boden mit meinen Harten flow methoden hinterlass ich Katastrophen.

(D-Flame )

Viele wollen genauso Stark wie unser Stamm sein das ist der Grund warum bei uns der Härteste mann Schleimt gibt es jemanden der Heisser werden kann nein 
wo sind wir daheim Frankfurt am Main

4x Hook (D-Flame)

Der grund das sie uns Stoppen wollen kann nur Angst sein

hinter dem Rücken reden und dann kurz Anschleimen

jetzt sind wir bereit und man kann gespannt sein

wo sind wir daheim ? Frankfurt am Main

Artista: Main Concept

Album: Coole Scheiße LP

Faixa: Rhetorik und Intellekt

Na gut, DavidPe ist wiedereinmal unterwegs, wenn Du dich mit mir anlegst, zerkrümmel ich dich wie nen Leibnizbutterkeks, ich werde dich zertrampeln, ich kenne keine rote, sondern nur grüne Ampeln, du bist ein Hampelmann, während ich der König bin, schlechthin, gib mir nur ein Microphon und ich werde das Kind schon schaukeln, ich werde dich vergaukeln, mit Schlägen so laut wie Pauken, Mann, werde ich euch Rabauken, vernichten mit Gedichten, das erpicht, denn mein Reim ist wie ein kleiner grüner Kaktus und er sticht, sticht tief in dein Gewebe, durchbohrt die Membran, vernichtet deinen Nucleus, vergiftet deine Blutbahn, mein lieber Schwan, jedes Organ ist erlahmt, gegen meine Antigene sind deine Antikörper gar nicht wirksam, Du bist arm, dein Organismus deletiert, vom klitzekleinen fiesen Virus DavidPe infiziert Rhetorik-kombiniert mit Intellekt ist die Art und Weise wie Zipfl in die Tasche steck, genau Rhetorik-mit Wissen kombiniert ist die Kombination aus der mein Können resultiert.

Ich kicke die Oratio, durchdacht mit Ratio, ernte die Laudatio, verursach Perturbatio, id est quod facio, ich bin ein Orator perfectus, nicht vom Intellekt neglectus, somit keinesfalls Subiectus, Rectus, mein Wissen niemals mißbrauchend, rezitierend und nicht fauchend, damit Zipfen das Genick verstauchend. Ich bin gegen Ausverkauf ein Skeptiker, du Müll-MC ein Hektiker, ein Ausverkaufsverdächtiger, ein äußerst Nieder- trächtiger. Ohne Würde, ohne Stolz, Du verkaufst deine Musik für Geld und tust was du sollst. 
Charakterlich gesehn bist Du so gut wie nix, kannst weder dem Glanz des Geldes wiederstehn, noch seinen Tricks. Der Mensch ohne Charakterstärke ist es, was ich hasse, nicht durchgehn lasse, links und rechts eine verpasse. Cogito ergo sum, doch Du bist dumm, kannst gar nicht cogitare, sondern eher Scheiße proclamare, drum bist du nichts, bestehst du nicht, nicht mal als Molekül, denn Davids Können cogitare und haben dafür Gefühl, ja, Mister Ausverkauf Du bist uns geistig unterlegen, auf allen Lebenlebenwegen untergeben.

Rhetorik-kombiniert mit Intellekt ist die Art und Weise wie Zipfl in die Tasche steck, genau Rhetorik-mit Wissen kombiniert ist die Kombination aus der mein Können resultiert.

Mein Mikro ist die Waffe und mit diesem töt ich die Müll-MCs, das bist Du, wenn Du kommerzielle Wege gehst, industrielle Schwänze bläst, Du verstehst, nach solchen bin ich auf der Jagd, aber auch nach jedem, der mich herauszufordern wagt oder böse Sachen sagt oder mich mit Scheiße plagt odert hinterlistig fragt-der landet in nem Sarkophag, denn keinem möchte ich im Leben raten, jemals den Versuch zu starten, sich mit mir zu messen, mit mir microphonzuschlachten, nach einer Position zu trachten, so meinen Zorn zu entfachen. Keine Chance, denn ich bin Meister von Beruf, egal, sa kojim jesikom, mein kleiner Scheißer Du versuchst, denn ich bin wortgewandt, mnogo jesika ja znam, und kommst Du auch mit 1000 Freunden, merk dir: ja sam nikad sam, denn meine Wegbegleiter sind Rhetorik und Intellekt, diese Kombination macht mich nahezu perfekt. So kick ich mit coolen Reimen Ethik, bleib auch immer in der Metrik, was wiederum der Erfolg bestätigt!

Rhetorik-kombiniert mit Intellekt ist die Art und Weise wie ich Zipfl in die Tasche steck, genau Rhetorik- mit Wissen kombiniert ist die Kombinatiation aus der mein Können resultiert.

Artista: Nico Suave

Album: Nico Suave 2001

Faixa: Vergesslich

chorus/ 
warum bin ich so vergeßlich/ ich weiß es nicht/ der scheiß bringt mich aus'm gleichgewicht/ sach mir: warum bin ich so vergeßlich/ich kann's nicht sagen/ und wenn ich's wissen würde, würd' ich nicht fragen/ eh jo/ warum bin ich so vergeßlich/ich weiß es nicht/ der scheiß bringt mich aus'm Gleichgewicht/ sach mir warum bin ich so vergeßlich/ich kann's nicht sagen/ und wenn ich's wissen würde, würd' ich nicht fragen/ eh jo/ vor gar nicht all zu langer zeit, ich erinner mich noch/ war ich bei meiner ärztin, weil ich innerlich koch/ ich hab sie gefragt, warum ich so oft dinge verge $ß /$ bin auch immer in streß und brauch dringend 'n test/ ich verge $\$$ alles und jeden um mich herum/ ich schätze das mittel dagegen habt ihr noch nich' erfunden/ ich ernähr mich nur von burger king und pizza hut/ haarausfall ist der grund warum ich meine mütze trag/ ich kann mir nichts mehr merken ich weiß nicht mehr/ verläuft mein leben schlecht oder rum wie im kreisverkehr/ ich weiß nicht mehr nenn' mir einer bitte den grund/ ich rauch zuviel man sieht mich nur mit kippe im mund/ dank meines lebensstils muß ich jetzt zum arzt/ solang' ich noch selber die fäden sieh, seh ich schwarz/ ich weiß ich muß mich ändern, sonst gehts berg $\mathrm{ab} /$ schon am nächsten tag, wenn ich's nicht wieder vergessen hab/ chorus/

bin ich krank oder gesund auf den ersten blick/ meiner meinung nach bin ich krank, meine ärztin nickt/ ich bin so vergeßlich, daß ich rund um die uhr/ 'n maneger und dann geh ich auf kur/ wenn ihr's erlaubt/ ich kann tage und nummer nicht im kopf behalten/ so müssen andere wie so oft meinen scheiß verwalten/ den geburtstag meiner frau hab ich letztens erst verpennt/ den jahrestag meiner beziehung vergeß ich permanent/ ich seh's ja selbst vorallem merk ich es auch/ das hält man nicht aus ich hab nur streß und ärger im haus/ "deine lebensweise ist zu krass für körper und geist"/ das sacht mir jeder jungs, andauernd hört man den scheiß/ dank meines lebensstils muß ich jetzt zum arzt/ solang' ich noch selber die fäden sieh, seh ich schwarz/ ich weiß ich muß mich ändern, sonst gehts berg $\mathrm{ab} /$ schon am nächsten tag, wenn ich's nicht wieder vergessen hab/ chorus/ ich bin so vergeßlich, ich zahl nie parkgebühren/ auf diesem weg bekomm ich 
es endlich mal zu spüren/ich erinner mich gut an vergangene zeit/ doch an gestern leider nicht, das geht anderen zu weit/ viele fühlen sich provoziert, meinen "tu as dagegen"/ warum ich wohl noch hier, junge du hast gut reden/ texte, die ich neu schreib, muß ich x mal lesen/ um sie live zu presentieren, als sei nichts gewesen/ komm mir nicht mit meinem zahlen- oder namensgedächtnis/ seid sicher, daß ich mich nicht erinner, suave verschecht es/ seit einiger zeit mach ich hier den selben test/ wer hält mich fest, weil mir wohl nicht mehr zu helfen ist/ dank meines lebensstils muß ich jetzt zum arzt/ solang' ich noch selber die fäden sieh, seh ich schwarz/ ich weiß ich muß mich ändern, sonst gehts berg $\mathrm{ab} /$ schon am nächsten tag, wenn ich's nicht wieder vergessen hab/ chorus/

Artista: Opa

Album: Unterwegs

Faixa: Zuhause und daheim

Statler:

Schon wieder abermals damals war es besser? Quatsch, das ist Dein Messer. Ich laufe in meine Zukunft weiter, spiele immernoch heiter Tetris statt Quake. Scheiter daran, wenn etwas nur fett ist, denn ich mag es, wenn es einfach nur nett ist. Dein Abc nenne ich noch Abcdefghijklmnopqrstuvwxyz. Dazu ab und zu Nebensätze die ich setze. Anglizismen verweise ich auf ihre Plätze und wegen Trends mache ich mir bestimmt keine Hetze. Graue Zellen verliere ich schon genug beim leben, da brauche ich nicht noch einen heben. Vonwegen. Genug erleben tue ich schon beim Aufwachen und brauche deswegen keine Schwüre auf Pillen oder synthetische Sachen machen. Ich kann auch ohne lachen. Nur dieses Husch-Husch, dieses Extreme. Und wenn ich nicht kusch bekomme ich schnell Probleme. Schon allein, wenn ich nur etwas erwähne und mich am Ende in Sicherheit wähne. Das geht nicht. So ein alter Typ kriegt doch nichts mit. Woher kennt der einen Hit? Seit wann sind Opas fit? Nun ja, langsame Rhythmen heißt nicht, dass ich nicht fit 
bin. Keine Sprüche über Deine Mutter bedeuten, dass junge Kücken mich noch nie erfreuten. Und eine fehlende Choreographie ist nicht wegen meinem Knie, sondern weil ich eine Sitzgelegenheit vorziehe, oder wie?

Waldorf:

Viel zu viele, viel zu ungerade fade Stilpfade. Labe Dich an der Vielfalt unseres Geradeaus. Geradeheraus. Auseinander auf das Ziel zu unserem Stil zugewandt, wandelnd. Neuster Stand unserer Dinge übersendend überspringe ich die Distanz zwischen Opas Eigenarten und Dir der Du Dich, wenn statt basslastig wider erwarten live lästig lasch, fragen musst, was Du hier machst. Kamst Du doch auf einen Sprung, den Du in unserem Publikum so wie wie bei mir so gut wie nie findest, da wie Du Dich auch windest wilde Jahre vergehen. Zumindest sollten. $\mathrm{Zu}$ sehen an faltigen Aussehen und all den ungewollten Gebrechen. Problem: Fehlt nun beim schnell Sprechen die Puste und Beats mit viel Bässen hören sich mit Hörgerät an wie Sven Väth, dann ist es Zeit etwas zu ändern. Entweder den Tag zu verschlendern im Stadtpark, mit Leuten von gestern über Blader lästern oder eben dem bisschen Leben das bleibt. Weisheit dieses lies leise in Liedgut unzeit- und greisgemäß Ausdruck zu geben. So legen wir uns ins Zeug, riskieren einen Infarkt für euch, flammbieren den Markt aalglatter Boys. Betagt ist angesagt. Aus totgesagt wir Neues. Am Start die Abfahrt Gießen, offenbart als Kaffefahrt mit anstatt Kaffee Tee, auf die Verkaufsschau warte vergeblich, da unsere Rente zwar nicht horrend doch reichlich reicht. Koste unsere Band, Kost und Logie wie rüher, als Rapstar noch nicht mehr wert war als Sprüher. Du noch Kettcar fuhrst. Tja, jetzt tschurst Du Autoradios und ich werde das Gefühl nicht los, dass es höchste Zeit für Opa war.

Artista: Plattenpapzt

Album: Full House / 2000

Faixa: Wenn Zonies reisen... feat. Tefla \& Jaleel

Jaleel: 
Der Plattenpapzt und ich, wir sind so DJ Kollegen, wissen beide was es heißt Menschenmassen zu bewegen, Schnulli-Beats bleib'n bei mir heut' in der Kiste, pack nur Underground-Hip Hop und mach mich auf die Piste, in Richtung Chemnitz-Nord, vorbei an Burger King und Co, 'n alter Zonen-Bau malt die Skyline aus Beton, zisch nach Erfurt, mit Vollgas geht's weiter Richtung Frankfurt, mein Polo säuft wie Harald Juhnke, ich brauch nen Tankstop, treff auf Fettbäuche am Truckstop mit Schweiß im Haar, bezahl mein Sprit, trink mein Kaffee auf Ex bevor ich weiter fahr, nochmal zum Pissoir, laß Druck vom Ventil, zahl ne Mark für die Putzfrau mit derbe Klo-Apeal, setz mich an's Steuer, doch bevor ich anfahr, fällt mein Blick auf nen Typen, winkt mit Daumen im Anschlag, und da Gesellschaft ja bekanntlich niemanden schadet, is es klar, daß Jaleel ab jetzt mit Sozius durchstartet.

Refrain:

Zwei Zonies auf der Reise, wollen Beats statt Banan', setzen Studios in Flammen, so better ring the alarm, wir leben aus'm Koffer, reisen durch unsere Zeit, wat wat, seid ihr bereit? Ja klar sind wir bereit! $2 \mathrm{x}$

Tefla:

B95 mit halbnackter Frau die fragt ob sie mal blasen kann, stundenlang stand ich am Straßenrand, bin vorher fast gerannt, doch nich mehr jetzt, weil ich vor Blasen nich mehr rasen kann, Langeweile treibt mein Finger bis zur Nasenwand, da schreit es von der Tanke: "ich nehm dich mit, eh", wohin? "Nach Düssel-City", oh shit eh, was für'n Glück, eh, ich steig in seine Hütte, mach mich lang im VW Polo, und denk "na geiles Ding, da wird's ja doch kein Tefla-Solo", im Radio läuft Mixtape unterbrochen durch Verkehrsfunk, 
auf uns'rer Strecke Stauschwerpunk, überblendet von Werbung, geht es weiter in chartsgeschwängerter Playlist, der Radio-DJ wählt Travis, alternativer geht's eh nich, dann eben nich, also wieder zurück zum Tape, und kurz nachdem ein Geisterfahrer uns're Autobahn belebt, Stop an Go, "Ring, Ring", das Mobilfunktelefon ringt, es is Jörg aus'm Studio, fragt mich wie ich den Beat find', mittlerweile telefoniert Jaleel mit jemand wegen Beats, dessen Name mit P beginnt und der gerade im Studio sitz, der LKW neben uns besetzt mit Holger und Ruth, sie trägt sicher Strapse, er sicher nich doch dafür Cowboyhut, "Dicker Stau, wirf mal die Warnblinker an", wir verlassen den Wagen zum Unfallort voller Tatendrang, es schau'n uns zwei Gesichter an: MC Wack und DJ Got No Skill, sie blieben unverletzt wir rufen nur`s ADAC-Mobil, Die ganze Zeit spukt mir Jaleel durch `n Kopf, ich denk den Namen kenn' ich doch, dreh mein Ohr in Richtung Box, dort läuft gerade n Track auf'm Tape im Tapedeck, mit nem Chorus den wir beide kennen, den jeder von uns mitrappt, "Tefla, Jaleel, Cocktail Twins" etcetera p.p., kennt ihr das Gefühl wenn einem ein Flutlicht aufgeht, darum fragt "bist du dumm" oder sagt, daß ich senil bin, denn am Ende merkte ich, daß wir ja Tefla \& Jaleel sind.

Refrain

Jaleel:

So um die 10 Liter Kaffe später und 6 Stunden Fahrt, treten wir die Tür ein und schrein: "Die Zonies sind am Start", und wollen ruffe Raps treten in der Ruhrpott-Metropole, wat los Mucho, leg mal n Beat auf die Konsole! Der Scheiß burnt uns, vergiß dein Graß, das ist Headrush, gegen eure Mau-Mau-Beats sind die hier Royal Flush, einfach tighter, ein Level weiter, scheiß auf Drogen! Ne Studiosession mit den Jungs macht mich breiter! 
Schnell noch mal rüber in's Bad um uns frisch zu machen, bevor wir Kabel vernabeln mit Raps und Monitore krachen, Mikro an und nen Kopfhörer am Ohr, erzählen Cocktail Twins Geschichten für jeden Schulkorridor, scheiß auf Fake-Hardcore, heut‘ steh'n Zonie-Raps im Plan, wenn Phlatliners bei Headrush die Fader hochfahr'n, sind Ärsche am bewegen, shaken, Köpfe am nicken, denn das ist Hip Hop pur, was wir in eure Stuben schicken.

Refrain

Artista: State Of Departmentz

Album: That's Real Underground

Faixa: Wer sind wir

Part 1

Hallo liebe Leute ich bin der SLASH

ich komme von dem Staat und finde es einfach wunderbar

Der Phil I P und der Slash

das sind beides Brüder also jetzt ist alles klar

Ich erkläre Euch die Lage von allen Dingen hier

in einem Reim von mir

Zu Euch soll dieser Reim auch gehen,

Ihr sollt ihn Euch anhören und Ihr sollt ihn auch verstehen

Er ist garnicht schwierig, denn er ist über mich,

ich reime was ich will und ich sag es aus meiner Sicht

Sicherlich? Sicherlich!

Aus meiner Sicht ich gehe zurück zum Thema sonst verreime ich mich

Also Königs T ist seit langem schon dabei,

Er kratzt seine Kratzer ganz flüssig, froh und frei

Ich hoffe nun das Ihr mehr über uns wißt,

Ihr kennt nun meine Lage und sie ist wie sie ist. 


\section{Part 2}

Vorstellen möchte ich mich, mich und mein Charakter, ich bin ein Reimtreiber, treibe Reime vor mir her.

Als Schäfer meiner Herde verpacke ich die Beschwerde, überziehe damit die Erde, auf das es besser werde.

Aber dann, spitz Dein Ohr, P.H.I.L., Phil trägt es Dir vor: Ich reime meine Reime, meine Reime reime ich für mich, ich reime meine Reime solange, bis du zusammenbrichst. Ich dehne die Grammatik, verdrehe sie aus meiner Sicht, beschleunige die Worte, und so verstehst Du manches nicht. Royal T, am Fader dominiert er, manipuliert er, manchmal kreiert er, benutzt die Plattenspieler als Rhytmusinstrument, 1000 Vinylscheiben dienen Ihm als Fundament.

Er mischt die Platten aus seinem Regale, Instrumentale zu einem Finale.

Artist: Tefla \& Jaleel

Album: Splash 2000 Event Sampler

Faixa: Ein Tag am See

SPLASH! Meine Damen und Herren. Ja, da geht einiges, da geht einiges auf'm SPLASH! Meine Damen und Herren. (3x) Richte deine Kamera in diese Arena.

Jaleel: Ich bin noch derbe geflasht vom Vortag zu viel gezecht. Fühl mich schlecht, brain dead, wenn sich Alkohol rächt, also Kippe an die Lippe und zum Cateringzelt in der Hoffnung ein bis zwei Käffchen retten die Welt. Ziemlich voll hier, treff auf meine Kompasen, tausch Coupon gegen Rührei und setz mich zu ihnen auf den Rasen. Ich würd ja gerne mit euch labern, wenn ich nur mehr Zeit 
hätte. Jungs schönen Tag noch, mach jetzt Morgen-

toilette . Putz den Pelz von den Zähnen und zum pissen

raus gehen, treff auf Tefla mit

Augenringen, die nach Kissen aussehn.

Tefla: Morgen, Dicker, gut geschlafen?

Jaleel: Auf keinen. Eher Schlammschlaf und unter

meinem Zelt lag 'n Stein. Hab kein Auge zugemacht und

bin noch ziemlich im Arsch, hab aber Grass auf Tash,

bau mir 'n Spliffi, extra large yo. Jetzt seh' ich Dinge

schon mit anderen Augen und lass Regen Sonnenschein

sein für’s SPLASH 2000.

Ey yo, was geht ab? Meine Damen und Herren. Chemnitzer am Drücker - bis der Arzt kommt. SPLASH!

Meine Damen und Herren. Chemnitzer am Drücker - bis der Arzt kommt. Ey yo, was geht ab? Meine Damen und Herren.

Relax Mann, wir sind jetzt dran. Chemnitzer am Drücker mit Phlatline-Sticker (?).

Tefla: Bei mir so Schlafsand aus den Augen und auch schnell Belag vom Zahn, sonst platzt er ab durch’n Bass, das ist nix für Jungs die Kronen haben. Mein erster Gang über'n Zeltplatz war erklärbar durch den Satz,der Umgang mit Drogen will geübt sein wie Cutz. Ich könnte wetten, jeder hier freut sich schon auf den Einlass, saugt Flair in sich auf, bis da keines mehr reinpaßt und wenn da mal noch das erste Bier im Magen ist, bringt's das Fass zum überlaufen, wie Taubenkragenschiss (?). Die Leute sind erstaunt, doch wer hier an Nessy denkt wird belehrt, wenn er hört Piranha, Kay for President. Immer wieder fragt mich einer, wieviele Zuschauer es jetzt gibt, und ich sag', seh ích jetzt aus wie der Rechenstäbe schiebt. Natürlich nicht, also schlag ich mich nach hinten durch's Dickicht, 
vorbei an Jungs, die beim Breaken und Sprayen wer dick ist. Ich hab so ein, zwei Stunden rumgebracht, meine Aufregung mit umgebracht. Ich glaub, dass ist heute unser Tag, vor'm Auftritt noch 'ne Runde Schach. Ey yo, was geht ab? Meine Damen und Herren. Chemnitzer am Drücker - bis der Arzt kommt. SPLASH!

Meine Damen und Herren. Chemnitzer am Drücker - bis der Arzt kommt. Ey yo, was geht ab? Meine Damen und Herren. Relax Mann, wir sind jetzt dran. Chemnitzer am Drücker - mit Phlatline-Sticker (?).

Jaleel: Ich werf' 'nen Blick auf die Running-Order, eh, ich mir mein Mikro forder'. Spüre wie meine Hände zittern, während ich mir meinen Text verstotter', geb' ich Tefla noch 'nen kräftigen Schmatzer und hoff' der SPLASH!-Gig verläuft für Cocktail-Twinz ohne Patzer. Ich meine, wenn $13.000 \mathrm{Headz}$ am Start sind und in Fahrt sind, treiben 26.000 Augen schnell mal in den Wahnsinn. Der erste Schritt ist der schwerste, sag' Hallo ins Mikro und flow mit Introtext on Stage und starte unsere Show.

Tefla: Ey, all die Hände, die wir hochgehen lassen wie Landminen wandern wie 'ne Sanddüne, überstrahlt vom Licht bis zur Bühne, sind wegweisend, zeigen gen Himmel wo heute das Limit liegt, während sich mittlerweile jede Hüfte zum Takt mittig wiegt (?). Glücklich sieht der aus, der Kalorien nicht im Leerlauf verbrannt hat. Alle sind gleich, keiner fragt wie ist denn der drauf. Weil ich weiß, wenn's heut' ein Motto gäb', unter dem genau das Ding hier steht, wär's HipHop pur statt Love Parade. Ihr seht: Chemnitz lädt zum Festival, kein Maskenball. Keine falschen Images, wir lassen zusammen die Korken knallen! Ey yo, was geht ab? Meine Damen und Herren. Chemnitzer 
am Drücker- bis der Arzt kommt. SPLASH!

Meine Damen und Herren. Chemnitzer am Drücker - bis der Arzt kommt. Ey yo, was geht ab? Meine Damen

und Herren. Relax Mann, wir sind jetzt dran. Chemnitzer am Drücker - mit Phlatline-Sticker (?).

Jams, die vom Fame her auch New York erreichen. SPLASH!

Jams, die vom Fame her auch New York erreichen.

Chemnitzer am Drücker - mit Phlatline-Sticker (?). Meine

Damen und Herren - mit Phlatline-Sticker (?). ( ??? ) my

favourite shit.

Artista: Der Klan

Album: Katzengold / Ultimate Chiefrockers 12"

Faixa: Ultimate Chiefrockers

\section{GERMANY:}

Ich komm in Gottesnamen, getarnt wie Soldaten im Sudan.

Gib Gas auf 16 bars, bin hart wie Jesus Steinschlag.

Bin high am Start, speicher Pflichten in mein Lebensschritte.

Never change position, Minden schärft Thats how it,s writen.

Prägen Grundlagen entsprechen.

Noch in zich Jahren prallen Kaisergaden mit Atentaten.

Setz mich ab wie Metastasien, explosiv wie Dynamit.

Teste MCs in Überdruckkabin brenn wie Turbin.

Flüssig wieBenzin, Germany sendet Raps bis dein Hirn brennt.

Coseng Konkurenz wird versenkt und späer angeschwämt.

Nen Angebot du fliesst oder bist tot wie der Kommonismus

denn ich disse gnadenlos jeden Bimbo auf meim Intro.

Ultimate Rocker mit dem Kingflow gibt Stylelessons und Infos.

Grossraum Discos, kommfrisstlos ans Kreuz wie Christus.

Meine Jungs in Tarnjacken ziehen Waffen zu schnell für Zeitraffen.

Bestatten Mannschaften an Massen mit Zaunlatten in Staatsbaraken.

Eingestanst mein Wappen, die hohen Herren reisen im Todesstern. 
Mehr Mann als Bundeswehr die Leichenreste untern Teppich kehrn.

REFRAIN

LORD SCAN:

Ich sach euch letztens kam mir mal són mieser Faker quer,

Mann 'nen Hurensohn mit Edelflair, 'türlich war sein Schädel leer,

er hielt sich für den Besten, dann wurden seine Beine schwer,

ich denk ich war noch fair, nur Props kricht der jetzt keine mehr.

Ich sach noch so :"verflucht!, merk dir besser was du tust,

denn bricht der Klan Tabus hör'n sogar tekknozombies Blues,

Chiefrockers bringen Headlines in den täglichen Rapnews,

danach war für ihn sense, ich war ihm wohl zu konfus."

Wesentlich im Biz is 'nen stabiles Genick,

sowie Zehnkämpfergeschicklichkeit in jeder Rubrik,

so langsam mach ich meinen Wahnsinn publik,

produzier den nächsten Undergroundhit vorerst in der Bundesrepublik.

Es werden Ansichten geschliffen, vornehmlich beim kiffen,

Ich hass das, mein Stil is allzuoft vergriffen.

Gebt euch meine Lines und lasst den Rest der Junkies sniffen,

reales wird gelobt, nicht reales ausgepfiffen.

Wenn SuperEuroChartProducer mit den fingern schnippen,

kippen ganze TeenieSippen wie Lemminge über Klippen.

Bin ich vorm Akai am trippen macht keiner mehr Zicken,

denn mein Scheiß ist längst bereit den ganzen Erdball hinterher zu kicken.

Macht's euch bewußt, kommt erstmal in den Genuß,

ich versorg den Kopf mit Shit bishin zum goldenen Schuß.

Noch liegen Lupenreine Meilensteine unter Verschluss,

es ist schon bald mein Plus, das ich ersinne was passieren muß.

\section{REFRAIN}

ITALO RENO:

Klan Kumpanen die schonwieder von der Norm abweichen

In Mindens Zeichen Statisten zum letzten Marcsh begleiten

Machen Raps härter als Favela Polizisten 
Wir hab`n hier alles am Start Nutten, Christen, tote und Fahndungslisten

Meine Artisten speichern Wissen aus Schriften

Verpack` Touristen in Kisten, und heiz` euch ein mit kalten Fingerspitzen

Klan in vordeter Front zerlegt dich Inflagranti

Reno`s Army umfasst Soldaten bis zur Kalahari

Harte Geschosse lehren Kolossen das Kotzen

Wir komm` aus Minden, die stätte des Verräckens deiner Streckenposten

Jungs die strotzen lass`ich parieren auf Lattenrosten

Wir chillen inGrotten, und können schneller als der Schatten boxen

Unser Debüt ist Spitzenreiter im Menü

Wir brennen auf jedem Vinyl zuviel, c`est la vie, kein Spiel

Klan-Kamikaze-Mafioso, ITALO-RENO

Stellt die Welt auf n Kopf, und blockt Elektroschocks mit Sender- Mikros

Notiert die Aussagen der drei Bonitos

Mit Stiften nd flinken Fingern brechen wir Streckenrekorde San Marinos

Crews finito im Archiv der Kripo, mein Trio ist heisser als Nitro

Und burnt dich weg wie Zero Zero

Denn Mindens Verticker machen Beats härter und dicker

Sind die Lyrickillerkicker...Du Ficker...

Artista: Eins, Zwo

Album: Gefährliches Halbwissen LP 1999

Faixa: Die Omi aus dem ersten Stock

"Was soll ich euch noch erzählen?..."

"Eine kleine Episode um das klarzustellen..."

Reiß den Vorhang auf

schmeiss die verdammten Lampen an

keine zeit für spielkonsolen

mein leben ist jump \& run

keine zeit zu verschwenden

und fängt erst drei die frühschicht an

bleibt keine zeit für lange weile \& müssiggang 
das ist die episode von zwei seelen die einsam starben weil sie ausser wenig schlaf scheinbar nichts gemeinsam haben tag $\&$ nacht liegen wir wach im kopf nur ach \& krach sie glotzt fernsehen, ich schreib geschichten mit lach und sach unter ihrem parterre auch wenn freunde nachts texten da und mach tracks in der hoffnung er packts nächstes jahr ein prachtexemplar in sachen beats und texten aber ein versager in sachen abschalten und relaxen es gibt genug was einem den gerechten schlaf verdirbt auf diese art \& weise hab ich manch ein schaf addiert sich den leeren kopf zu zerbrechen, hat zur zeit kein zweck ich dreh mich nochmal um und bin "...weit,weit weg..." Refrain:

$\mathrm{ab}$ und zu und $\mathrm{ab}$ und zu oft blick ich zu boden "...was soll ich euch noch erzählen..." ausser ein paar kleinen episoden $\mathrm{ab}$ und $\mathrm{zu}$ und $\mathrm{ab}$ und andauernd schau ich nach oben "...was soll ich euch noch erzählen..." ausser ein paar kleinen episoden von der bald im ganzen land bekannten omi von oben wir wohnen nicht wand an wand nur meine decke ist ihr boden bald im ganzen land bekannt die omi von oben wir beide wohnen nicht wand an wand nur meine decke ist ihr boden erst nach etwas katzenwäsche und zwangshygiene gewöhnen sich die knochen langsam an wochenanfangsmigräne ich geh los, kauf scheiben und machs fast zum melodram zelebrier das reimen von schlabberjeans und cellophan wieder zu haus fragt manch ein nachbar wattn dat nur das bass attentat von einem der an allem statt an platten spart durch hohle wände schallen sax und beat wie zeter und mordio doch nur sie sagt ja zum lied und spiel später arkodeon schiebs auf die chemie wie ham uns nie übers wetter ausgequatscht nie gegrüßt und nie zusammen durchs treppenhaus gelatscht 
aber wenn ich mir jede nacht um ihre bronchitis sorgen mach

weiß ich da is doch noch jemand und liegt bis morgens wach ich wette sie liebt diese beats weit mehr als man denkt weil sie jede baseline kennt, seit flavour flavt nur am halsband hängt noch mehr sounds zu suchen hat zur zeit kein zweck ich speicher $a b$, dreh mich um und bin

"...weit, weit weg..."

\section{Refrain}

$\mathrm{ab}$ und zu und ab und zu oft schau ich zu boden

"...was soll ich euch noch erzählen..."

ausser ein paar kleinen episoden

$\mathrm{ab}$ und zu und $\mathrm{ab}$ und andauernd blick ich nach oben

"...was soll ich euch noch erzählen..."

ausser ein paar kleinen episoden

von der bald im ganzen land bekannten omi von oben

was soll ich euch noch erzählen

meine decke ist ihr boden

bald im ganzen land bekannt die omi von oben

was soll ich euch noch erzählen

was soll ich euch noch erzählen

was soll ich euch noch erzählen, was ihr nicht selber wisst

wir beide teilen ein leiden obwohl sie soviel älter ist

ich hab nur eine kleine episode um das klarzustellen

und es gibt überhaupt kein grund bei ihr nicht mal zu schellen

alle zweifel sind weit hergeholt wie auslandskost

weil im flur ist oft genug geruch von hausmannskost

und ich schmachte nach futtern wie bei muttern und nach schöner wohnen

nachm kaffeeklatsch und nach ihren verwöhnaromen

sie soll ruhig wissen, dass egal wieviel props ich hättete

ich ohne ihre ruhe fast das chillen verlernt hätte

hab zu selten auf den wohlverdienten schlaf geachtet

und auf diese art und weise schon ein manch ein schaf geschlachtet 
zwei seelen sind einsam weil sie scheinbar nichts gemeinsam haben die omi aus dem ersten stock und einer von den derbsten reimern noch vorbeizuschauen hat zur zeit kein zweck ich dreh mich lieber noch mal um und bin

"...weit, weit weg..."

Refrain

$\mathrm{ab}$ und $\mathrm{zu}$ und $\mathrm{ab}$ und $\mathrm{zu}$ oft schau ich zu boden

"...was soll ich euch noch erzählen..."

ausser ein paar kleinen episoden

$\mathrm{ab}$ und zu und $\mathrm{ab}$ und andauernd schau ich nach oben

"...was soll ich euch noch erzählen..."

ausser ein paar kleinen episoden

von der omi aus dem ersten stock, die mich aus der reserve lockt

$\mathrm{ab}$ und zu und $\mathrm{ab}$ und zu oft schau ich nach oben

meine decke ist ihr boden, wr wohnene nicht wand an wand

die omi von oben ist bald im ganzen land bekannt

$\mathrm{ab}$ und zu und $\mathrm{ab}$ und zu oft schau ich nach oben

"...was soll ich euch noch erzählen..."

"...eine kleine episode um das klarzustellen..." (2x)

Artista:Thomas D

Faixa: Uns trennt das Leben

Und wie oft hast du schon die Nacht mit einem Helden verbracht?

Und bist am nächsten Morgen neben dem Teufel erwacht?

Ich stand am Rand deines Bettes und war ziemlich verranzt, doch ich hatte längst meinen Samen in dein Hirn gepflanzt.

Mein Bewusstsein blieb am Schweben und mit jedem Atemzug

krieg ich vom Leben nicht genug.

Kontrolliere meinen Flug, verharrte einen Moment, wundervoller Augenblick, der die Schönheit deiner Welt durch meine Augen schickt

und dennoch zieht mich mein Weg weiter und dich von mir weg.Du vergräbst, was war unter deinem toten Haar. Ich frag mich jeden Tag, 
wirst du mir jemals vergeben? Du bist bei mir. Uns trennt das Leben!

Das hier geht an alle, die mir ihre Liebe gaben.

Es war schön ein Stück davon gehabt zu haben.

Das geht raus an alle Leute, die ich geliebt.

Es ist schön, dass es euch gibt, ja.

Das hier geht an jeden, der mir zu nahe stand

und von mir verletzt wurde durch das, was uns verband.

Jetzt trennt uns das Leben und doch: Ich lieb dich immer noch.

Ich war die Zukunft für dich doch das ist jetzt Vergangenheit.

Und ich schätze ein: Tut mir Leid, tuts nicht mehr.

Du warst so voller Erwartungen. Ich war so leer.

Du hingst so sehr an mir, wir wurden zu schwer. Ich ließ ein paar Federn, es half sicher nicht. Ich schrieb: Liebe dich! Und ich liebe dich.

Ich werde meinem Karma folgen, ich kann in die Zukunft sehen.

Lass es dich nicht zerstören, lass uns auf die Liebe schwören!

Schick die Dämonen in die Hölle, wo sie hingehören. Im Glauben daran, dass nichts bliebe ohne die Liebe.

Das hier geht an alle, die mir ihre Liebe gaben.

Es war schön ein Stück davon gehabt zu haben.

Das geht raus an alle Leute, die ich geliebt.

Es ist schön, dass es euch gibt, ja.

Das hier geht an jeden, der mir zu nahe stand

und von mir verletzt wurde durch das, was uns verband.

Jetzt trennt uns das Leben und doch: Ich lieb dich immer noch. (2x)

Was würden wir erfahren, wenn wir alles vorher wüssten?

Vielleicht brach ich dein Herz, als wir uns küssten.

Doch vielleicht bist es du, die unserer Liebe diesen Tritt verpasst, wenn du bereust, dass du mich je getroffen hast. Und vielleicht ist es ein Gesetz, das es in deinem Leben gibt, dass man für jeden Tag im Himmel einen in der Hölle kriegt.

Doch es gibt alles im Leben nur einmal und wenn es nicht so wäre, 
ich würd dich noch mal lieben und zwar doppelt so sehr.

Das hier geht an alle, die mir ihre Liebe gaben.

Es war schön ein Stück davon gehabt zu haben.

Das geht raus an alle Leute, die ich geliebt.

Es ist schön, dass es euch gibt, ja.

Das hier geht an jeden, der mir zu nahe stand

und von mir verletzt wurde durch das, was uns verband.

Jetzt trennt uns das Leben und doch: Ich lieb dich immer noch. (2x)

$<<<$ Support $>>>$

DEFLOK HipHopMagazin.com -> Das älteste unkommerzielle Hip Hop Mag straight aus dem Ruhrpott. Unbedingt mal abchecken!

BOMBING HipHopPromotion.de -> Promotion Agentur, welche Euch u.a. kostenlos Promostuff, wie Sticker, Flyer, etc. nach Hause schickt. Nebenbei supporten die Jungs auch div. Projekte [Eure?] umsonst! 